Florida International University

FIU Digital Commons

FIU Electronic Theses and Dissertations

University Graduate School

$7-1-2020$

\title{
The Cuban Revolution's Emotive Regime: A Decade to Remember, 1968-1978
}

Maite Morales

Florida International University, mmora037@fiu.edu

Follow this and additional works at: https://digitalcommons.fiu.edu/etd

Part of the Cultural History Commons, Latin American History Commons, Other History Commons, and the Social History Commons

\section{Recommended Citation}

Morales, Maite, "The Cuban Revolution's Emotive Regime: A Decade to Remember, 1968-1978" (2020). FIU Electronic Theses and Dissertations. 4466.

https://digitalcommons.fiu.edu/etd/4466

This work is brought to you for free and open access by the University Graduate School at FIU Digital Commons. It has been accepted for inclusion in FIU Electronic Theses and Dissertations by an authorized administrator of FIU Digital Commons. For more information, please contact dcc@fiu.edu. 


\section{FLORIDA INTERNATIONAL UNIVERSITY}

Miami, Florida

\section{THE CUBAN REVOLUTION'S EMOTIVE REGIME:}

A DECADE TO REMEMBER, 1968-1978

A dissertation submitted in partial fulfillment of

the requirements for the degree of

DOCTOR OF PHILOSOPHY

in

HISTORY

by

Maite Morales 
To: Dean John F. Stack, Jr.

Green School of International and Public Affairs

This dissertation, written by Maite Morales, and entitled The Cuban Revolution's Emotive Regime: A Decade to Remember, 1968 - 1978, having been approved in respect to style and intellectual content, is referred to you for judgment.

We have read this dissertation and recommend that it be approved.

Jorge Duany

Michael Bustamante

Bianca Premo, Co-Major Professor

Rebecca Friedman, Co-Major Professor

Date of Defense: July 1, 2020

The dissertation of Maite Morales is approved.

Dean John F. Stack, Jr.

Green School of International and Public Affairs

Andrés G. Gil

Vice President for Research and Economic Development and Dean of the University Graduate School

Florida International University, 2020 


\section{DEDICATION}

Para mamá y papá.

Gracias por darme la oportunidad de soñar. 


\section{ACKNOWLEDGMENTS}

This project is an accumulation of emotions including gratitude for the institutions, colleagues, friends, and family that supported it along the way. The research for this dissertation was conducted with the support of the Tinker Foundation Field Research Grant, Florida International University Dissertation Evidence Acquisition Fellowship, the Green School Morris and Anita Broad Research Fellowship, the Cuban Research Institute Eliana Rivero Research Scholarship, various institutions at the University of Illinois, Champaign-Urbana, Russian, East European, and Eurasian Center, and the University of Florida, George A. Smathers Libraries.

The project grew out my curiosity to learn about a time that I only knew of through the memories of my mother and the remnants of the Soviet Union that were my childhood toys. However, the idea of writing about emotions was not evident to me until I experienced daily life in Cuba as a researcher.

In Cuba, I was grateful for the enthusiasm and support I encountered from scholars and staff at institutions, including the Instituto de Historia de Cuba, Biblioteca Nacional Jose Martí, Archivo Nacional del Ministerio de Cultura, Archivo Histórico Provincial de Matanzas, Archivo del Periódico Girón, and Archivo de la Oficina Provincial de Estadística e Información en Matanzas. I am indebted to the generosity and warmth of Roberto and Lisette. While Lisette taught me how to find my way around Havana, Roberto showed me how to find the bright side to every situation (and if I did not, an afternoon walk to the Malecon would change that). 
I could not have written this dissertation without the support, friendship, and guidance of many individuals, including my talented, generous, and patient dissertation committee, Jorge Duany, Michael Bustamante, Bianca Premo, and Rebecca Friedman. I am also grateful for the mentors who taught me how to hone my skills along the way: April Merleaux, Aurora Morcillo, Peter Reill, Kenneth Lipartito, Okezi Otovo, and Gwyn Davies. I could not have done it without the colleagues who became friends and confidantes: Loraine de la Fe, Christopher Davis, Joseph Marin, Andrew Hart, Kyle Stein, Ricardo Pelegrin, John Ermer, Luis del Pino, Aymee Correa, Paola Salavarria Romero, Sebastián Arcos, and my CasaCuba family (María Carla, Lili, and Joe).

I would like to thank my family for their unwavering support and understanding from near and far. Finally, I would like to thank Marco Parra for making sure I ate, slept, and took a break in the last big push to the finish line. 


\title{
ABSTRACT OF THE DISSERTATION
}

THE CUBAN REVOLUTION'S EMOTIVE REGIME:

A DECADE TO REMEMBER, 1968-1978

\author{
by \\ Maite Morales \\ Florida International University, 2020 \\ Miami, Florida \\ Professor Rebecca Friedman, Co-Major Professor \\ Professor Bianca Premo, Co-Major Professor
}

While emotions were central for the victory of the 1959 Cuban Revolution, a decade later, feelings became an obstacle for the consolidation of the revolutionary government. During the second decade, growing disillusionment and dissatisfaction challenged the state's emotive regime. Within the first five years, Cubans engaged in one of the largest mass mobilization projects in the nation's history and failed to achieve a ten-million-ton sugar harvest. The revolutionary government reacted to the failure in various ways, but all dealt with emotions: from a major carnival revival in 1970 to the establishment of new tactics to satisfy consumer demand.

To understand the Revolution's second decade, my dissertation identifies the Revolution as an emotional regime, and officials and mass organizations as emotional managers. It also acknowledges that emotional communities coexisted with the emotive regime. The dissertation exposes some ways in which these communities legitimized and challenged the state's increasing control of the population. The project examines organization records, official reports, and the press. It finds that the failure of the 1970 
sugar harvest signaled a shift in the emotive regime and the tactics employed by officials to retain control and deter negative sentiments. On one hand, the state sought immediate and long-term solutions to quell unwanted, negative emotions, while on the other, ordinary people adapted the emotive ethos of the state to express their frustration.

This dissertation highlights how an analysis of emotive regimes allows scholars to explore the contours of everyday life in ways that will open possibilities for future scholarship. It also proposes a new periodization of the Cuban Revolution, identifying the emotions that often precede and remain beyond major historical events. 
TABLE OF CONTENTS

CHAPTER PAGE

INTRODUCTION

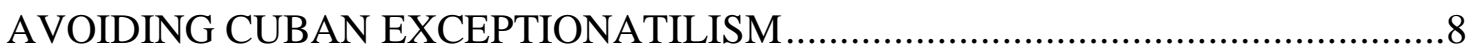

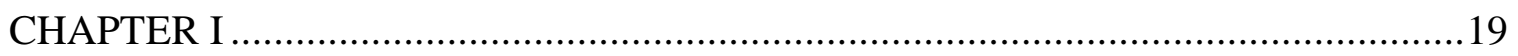

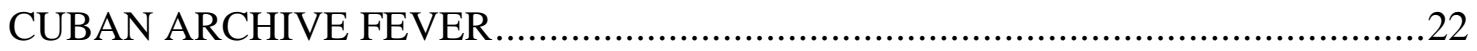

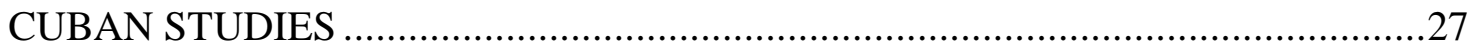

CUBAN ARCHIVES AND HISTORIES AFTER 1959 _...........................................32

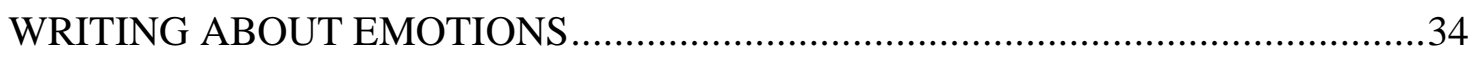

MIAMI: MERGING POLITICS AND EMOTIVE CURRENTS ……......................42

EXPERIENCES ON THE ROAD TO THE ARCHIVE …….................................45

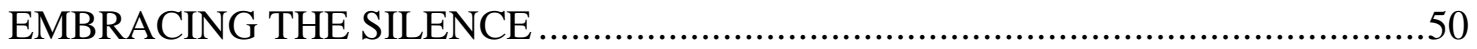

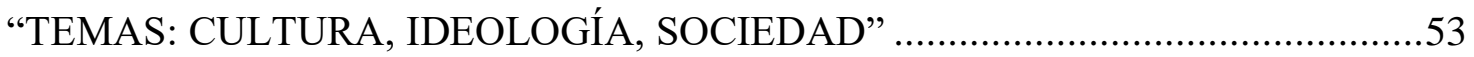

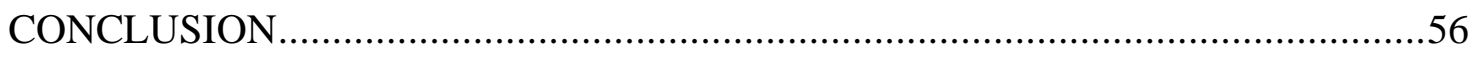

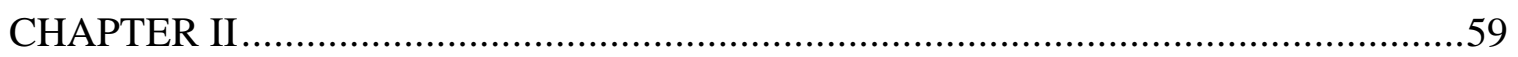

A FESTIVAL UNDER THE CUBAN SUN ………….....................................64

PACHANGA FOR ALL: PROMISES OF CELEBRATION AND THE RETURN OF

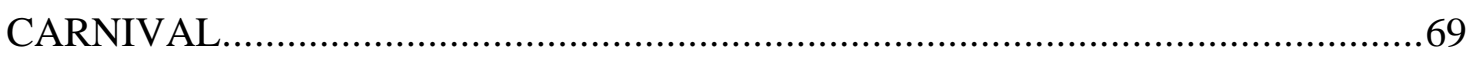

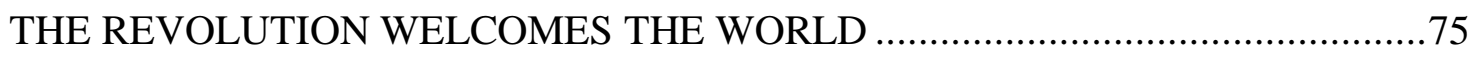

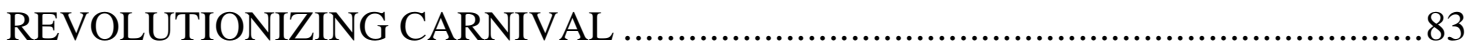

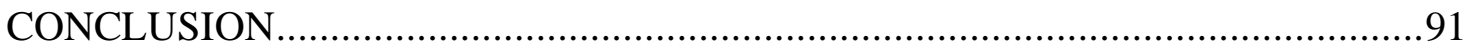

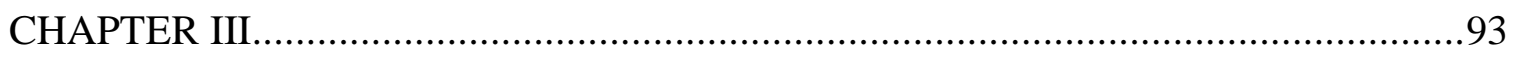

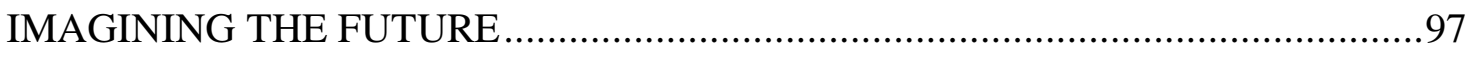

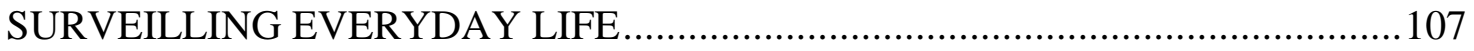

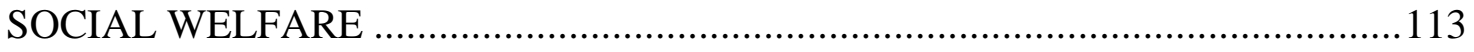

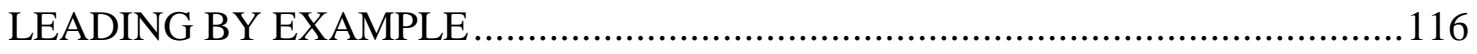

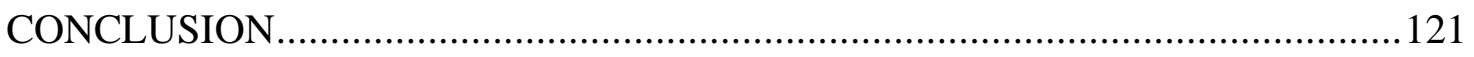




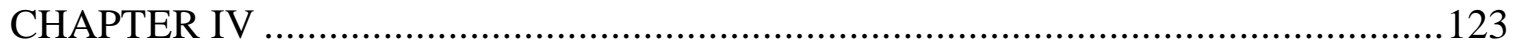

OSCAR LEWIS AND THE REVOLUTION'S BLACK MARKET .........................127

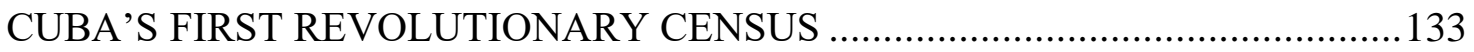

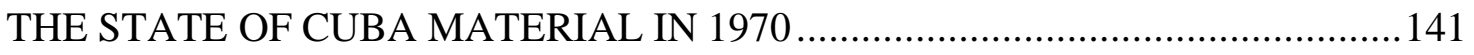

LOS SOVIETS, ICIODI, AND RATIONAL CONSUMPTION ............................... 144

THE EMOTIVE REGIME'S RATIONAL CONSUMER …....................................150

"ESPERO UNA SOLUCIÓN NO UNA JUSTIFICACIÓN” .....................................151

PLEASURE: THINKING BEYOND SATISFACTION ………….........................157

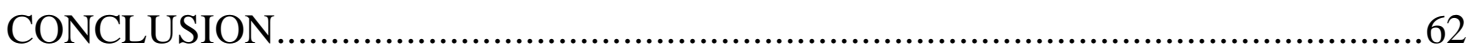

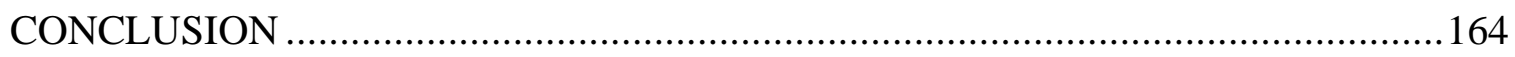

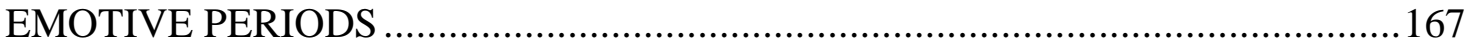

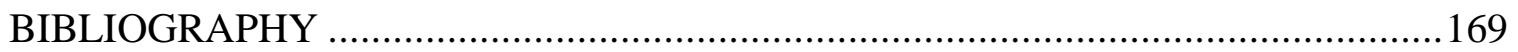

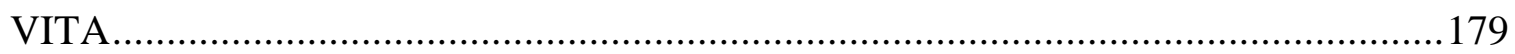




\section{INTRODUCTION}

Before Fidel Castro and the barbudos marched into Havana in 1959, feelings defined the revolutionary beginnings of political change. Cubans, moved by the possibilities revolution presented, joined the revolutionary struggle in cities and the countryside. Emotions bound the Cubans and transformed the Revolution into a popular form of national expression; in other words, it became an emotive regime that relied on popular emotional commitment. Officials, the managers of the emotive regime, played on collective and individual emotions to accomplish revolutionary milestones like the National Literacy Campaigns, but these emotions also required nurturing. Officials used celebrations, culture, and consumer goods to nurture emotional commitment. The repercussions of the country's economic struggles during the decade of the sixties undermined the early enthusiasm that marked the Cuban Revolution's first years. Officials exhibited confidence in the Revolution as an emotive regime when they declared the Revolutionary Offensive of 1968 and required mass volunteerism to collect ten million tons of sugar. When these massive efforts failed, officials resorted to emotional management to navigate the national disappointment. Their solutions to the emotional toll of the failure, from the return of festivities to studies of consumer demand, were vital for the endurance of the emotive regime and, in turn, the Cuban Revolution.

This dissertation contributes to the field of Cuban studies by contextualizing the history of the Cuban Revolution as a history of emotions. It recognizes that scholars writing about Cuba have dealt with emotions for decades, but they have not addressed these directly or applied the terms developed by scholars of emotionology. Using these 
terms, I argue, facilitates an interdisciplinary approach that engages not only other fields but also reveals new opportunities to write about dynamics of power, gender, and the everyday inside the Cuban Revolution.

While the study identifies emotions that defined the second decade of the Revolution, the dissertation emphasizes the role of officials as emotional managers, from individuals to groups, and how they responded to the emotions that threatened the stability of the regime. The project examines how Cuban officials, institutions, and everyday people enforced, navigated, and embraced various emotive discourses. It focuses on the second decade of the Revolution to highlight affective discourses in the face of widespread emotive shifts triggered by the failure of the Ten-Million-Ton Harvest. The history of emotions of this period reveals concerted efforts by officials, including institutions and mass organizations, to manage the emotive regime. Official's contained and overcame the mass disillusionment of the Ten-Million-Ton Harvest's failure with effective management of joy and pleasure. However, officials could not manage how individuals internalized and appropriated emotive discourses to express their feelings about everyday life. By the second half of the decade, disillusionment transformed into the frustration that seeped onto the editorial pages in local newspapers and state press. Despite the hurdles presented by the accumulation of negative emotions, state officials succeeded in managing affective repertoires and guaranteed the permanence of the Revolution's emotive regime.

Emotions are complex and involve a multi-layered process of interpretation, feeling, and expression that help historians analyze the intersectionality of social 
identities. Historian Lois Banner wrote that "emotions are often slippery and evanescent: [t]o capture their content, in the final analysis, may require the art of a poet as well as that of a historian." Writing about emotions is challenging, but as Peter and Carol Stearns argued in a watershed 1985 article, emotions are a valuable tool of analysis for historians. The Stearnses coined the term "emotionology," which they defined as "a useful term with which to distinguish the collective emotional standards of a society from the emotional experiences of individuals and groups." Emotionology requires a clear definition that differentiates it from emotion (feeling); the latter relates to the ideals and external factors, and the former refers to the actual experience. The Stearnses proposed emotionology to identify historical shifts and their impact on affective experiences. They explained emotionology as a "word saving term" as well through the history of the word tantrum, how it rose in popularity, and how its meaning transformed over time from "angry behavior in adults" to "a particularly childish fit." Here emotionology stood for "ideas about anger." Emotionology is the study of the links between emotions and society. Historical and societal trends and shifts shape an individual or group's affective experiences over time. The term became a defining moment for social historians as it helped make a distinction between societal structures and individual experience.

Throughout the nineties, social historians adopted the term and actively engaged with emotions and their historical significance; they also complicated our understanding of emotions and emotionology. William Reddy, building on the work of the Stearnses, described emotional liberty and suffering through his definition of emotives and emotive

\footnotetext{
${ }^{1}$ Ibid., 826.
} 
regimes. The term "emotives" highlights the discursive character of emotions. According to Reddy, "the emotive character of an utterance or gesture arises from the fact that the actor is trying to accomplish an act of self-management or self-exploration by making it."

However, saying, "I am happy," does not mean a person feels that way; one must consider the context of the utterance. Reddy defined this context through emotive regimes, a power structure closely linked to politics. The emotionology of a period or region is "managed" by the emotive regime. Reddy's regimes have two poles, strict or liberal, and societies tend to have variations of these. They are also closely linked to political structures. Thus, following Reddy's definition, the political structure "manages" or guides a society's emotionology, while the individual "navigates" these emotive discourses. Under a liberal emotive regime, individuals or groups have a strong sense of emotional freedom and exercise it by "[challenging] the reign of high-level goals currently guiding emotional management." When high-level goals come into conflict with internal feelings, the result is emotional suffering. High levels of emotional suffering result in emotional refuges or spaces (such as the theater) for the expression of conflicting emotions. Strict emotional regimes have a higher tendency to induce emotional suffering as they require not only regular emotive performances and rituals but also police feelings (and actions) that challenge the stability of the emotive regime.

While Reddy's work showed the importance of the discursive context in understanding emotional expression, Barbara Rosenwein complicated the emotional regime by identifying emotional communities. She agreed with Norbert Elias's notion of "civilizing process" in that that the history of emotions is part of the history of the state. 
However, she differed with Elias's "linear process of emotional control." In her definition, Rosenwein defined emotional communities as "precisely the same as social communities—families, neighborhoods, parliaments, guilds, monasteries, parish church memberships - but the researcher looking at them seeks above all to uncover systems of feeling." Emotional communities can coexist or rise in opposition to the regime and create shifts in emotionology; they have the potential to become one of Reddy's emotive regimes. ${ }^{2}$ The emotive regime and communities employ repertoires (images, words, and objects) of feelings to manage and express emotions.

In 2000, over a decade after the Stearnses coined emotionology, political scientist Damián Fernández’s monograph claimed that “few have explored the effect of emotions on political attitudes and action in Cuba." ${ }^{33}$ Fernández argued that to understand Cuba's political culture, one also needed to recognize the role of emotions and affective bonds that rallied the masses at pivotal moments in the nation's history. He identified two emotional repertoires as influential to the island's political culture: the politics of passion and the politics of affection. Fernández noted how emotions are not only destructive in cases of political oppression; they also help to erect and sustain political structures in Cuba. Rooted in history, the politics of passion represent the affective ties between people, and the moral ideals of political campaigns. The revolutionary movement of the

\footnotetext{
${ }^{2}$ Rosenwein is not comfortable with the full definition of Reddy's emotional regimes as having only one site of emotional refuge, the salon. Reddy's conclusion of one emotional refuge is due to his chosen case study: sentimentalism in France. Rosenwein implies that just as there are several emotional communities, there is more than one space for emotional refuge. Despite the disagreement on emotional refuge, Rosenwein agrees that one emotional community can rise to dominance and become one of Reddy's emotional regimes.

${ }^{3}$ Damián J. Fernández, Cuba and the Politics of Passion (Austin: University of Texas Press, 2000), 67.
} 
1950s leveraged the politics of passion and espoused moral rhetoric that sought to set the corruption and mass dissatisfaction with Cuba's political structure aright. Thus, the politics of passion not only helped in toppling Batista's corrupt government; it also propelled the triumph of the 26 th of July movement in 1959 . The politics of affection coexist with the politics of passion; the politics of affection refer to the affective bonds, such as parent and child, that justify the betrayal of political ideals. Fernández identified "four layers of beliefs" that made the Revolution "a Cuban political religion." These included informal, traditional beliefs, values linked to political ideals, "the corporatist legacy of the colonial period," and Castroism. ${ }^{4}$ These layers made the Revolution an "autochthonous cultural expression, meaningful to the Cuban people." The revolutionary movement resonated with Cubans because it echoed the political currents of Cuba's past political passions.

While Fernández brought "feelings back into the study of [Cuban] politics," historians also made strides to bring emotions into the study of Cuban history. Historian Louis Pérez describes how Cuba's struggles for independence in the nineteenth century transformed overtime in the national memory. According to Pérez, in nineteenth-century Cuba, "the nation [was] experienced by way of feelings." Therefore, he analyzes poetry as a vehicle for feelings closely tied to the ideals of the nation during this period. ${ }^{5}$ Pérez concludes that past national experiences of politics as passion created the conditions that

\footnotetext{
${ }^{4}$ Castroism refers to the personal beliefs of Fidel Castro as defined by Andrés Suárez. Ibid., 67-8.

5 According to Pérez, "poetry possessed the possibility of politics as emotions." Louis Pérez, The Structure of Cuban History: Meanings and Purpose of the Past (Chapel Hill: University of North Carolina Press, 2013), 48-50.
} 
would transform the 1959 Revolution to assume "metaphysical properties transcending the reach of human agency ...; the Revolution was history fulfilled." ${ }^{6}$ However, despite describing the power of emotions and making similar conclusions about the role of history and feelings in the evolution of Cuba's political culture, Pérez did not refer to Fernández's politics of passion and affection.

Historian Lillian Guerra's work also focused on Cuba's political culture and the history of narratives and counternarratives of the Revolution from 1959 to 1971. She returned to language and print culture to analyze the "radicalization of discourse." Guerra described the political culture of the Revolution as "a kind of popular nationalism defined as fidelismo."7 The description of fidelismo is similar to Damian Fernandez's understanding of Castroism. The difference is that Fernández views Castroism as "part of [the Revolution's] eclectic framework," while Guerra uses it as the framework to describe the evolution of Fidel Castro's grassroots dictatorship. ${ }^{8}$ Despite this difference, both concluded that emotions, whether in fidelismo as cultural religion or in Revolution as political religion, are key to understanding the Cuban Revolution and its meanings at different stages.

Despite a lack of intertextual engagement, the work of Fernández, Pérez, and Guerra indicate that to write about the Cuban Revolution requires an exploration of the

\footnotetext{
${ }^{6}$ Ibid., 241.

${ }^{7}$ Lillian Guerra, Visions of Power in Cuba: Revolution, Redemption, and Resistance, 1959-1971 (Chapel Hill: University of North Carolina Press, 2012), 13.

${ }^{8}$ Fernández, Cuba and the Politics of Passion, 59.
} 
history of emotions. ${ }^{9}$ The similar but different terminologies in the case of Fernández and Guerra complicate the possibility of an interdisciplinary approach; this is why I propose that historians adopt the terms coined by social historians to analyze emotions in the context of the Cuban Revolution. Fernández's politics of passion and affect recall Rosenwein's emotive repertoires and emotional communities, and the ideas of the Revolution as a political religion and fidelismo as a cultural religion are captured in Reddy's emotive regime (the dominant emotions and modes of expression).

\section{AVOIDING CUBAN EXCEPTIONATILISM}

In his 2017 contribution to the special issue of the Cuban magazine Temas, historian Michael Bustamante assesses the evolution of Cuban Studies within the United States for a Cuban audience. Bustamante is honest in his review that "despite the amount of scholarship about the Cuban Revolution, our knowledge about the social, cultural, and politics of revolutionary Cuba remains fragmented." ${ }^{10}$ Emerging U.S.-based scholars and their work reflect a conscious effort to write "Cubacentric" histories of the Revolution using culture as a lens and mining the state press. ${ }^{11}$ However, despite these efforts, practical and political challenges, including sources and access to Cuban archives, reinforce feelings amongst U.S.-based scholars that histories of the Revolution remain

\footnotetext{
${ }^{9}$ I searched Pérez and Guerra's books for a citation that acknowledged the emotive repertoires Damián Fernandez used in his work; in both cases I encountered an unexpected silence. Fernández cites Pérez's Cuba: Between Reform and Revolution (1995) in Cuba and the Politics of Passion (2000). However, Pérez and Guerra do not make any reference to Fernández in their respective monographs, The Structure of Cuban History (2013) and Visions of Power in Cuba (2012).

${ }^{10}$ Michael Bustamante, "Historiar la Revolución desde los Estados Unidos,” Temas (2017): 4-5.

${ }^{11}$ Michael Bustamante and Jennifer Lambe, The Revolution from Within: Cuba, 1959-1980 (Durham: Duke University Press, 2019).
} 
incomplete (or unbalanced) despite their "Cubacentric" efforts. Recognizing these challenges, Bustamante illustrates the possibilities of writing about the Revolution by identifying the institutional and individual efforts that are necessary. Lastly, he summarizes that outside of archival access, scholars also need to write about the Revolution from within. This exercise requires scholars to study how the meaning of the Cuban Revolution evolved beyond the sixties and the parameters of Havana.

This dissertation answers Bustamante's call for histories that "pluralize our understanding" of the Cuban Revolution not only by shifting the focus to the Revolution's second decade but also through a theoretical framework that facilitates the study of everyday life through emotions. ${ }^{12}$ It speaks to the work of previous scholars like Louis Pérez and Lillian Guerra by engaging in an analysis of the discursive culture of the state and how this culture shaped daily experiences. The chapters also illustrate the value of integrating Soviet historiography by U.S.-based scholars to study the second decade of the Revolution.

The terminology developed by social historians and Soviet historiography helps scholars of the Cuban Revolution avoid the pitfalls of exceptionalism in their interpretations. Guerra explains how the early impressions of the Cuban Revolution by Jean-Paul Sartre and the international Left strengthened the exceptionalism in the retelling of the Revolution's story. ${ }^{13}$ She debunked perceptions of the Cuban Revolution as an exceptional event and identified the consolidation of socialism without violence as

\footnotetext{
${ }^{12}$ Ibid.

${ }^{13}$ Guerra, Visions of Power in Cuba, 21.
} 
the "real" unique event. Guerra engages the historiography of the Soviet Union. This analysis shifts the focus from the fallacies of exceptionalism to the Cuban Revolution's and the early Soviet Union's "historical contingencies" for Guerra. ${ }^{14}$ She is interested in the ways that scholars writing about the Soviet Union analyze the evolution of identity and consciousness "in tandem with the development of socialism." Guerra hints at the inspiration behind fidelismo quoting Soviet Union historian Sheila Fitzpatrick's description of "a Stalinist mentalité ... to see things as they were becoming and ought to be, rather than as they were." Guerra concluded that the Cuban Revolution "remains distinctive" from the Soviet case because it transformed into a perpetual event. Guerra also showed that it is not fruitful to compare the Cuban Revolution, as an event, to the Russian Revolution and its “initial hegemonic phase.” However, Guerra's interpretation of Soviet scholarship and adaptation of Fitzpatrick's Stalinist mentalite demonstrates the value of Soviet historiography to studies of the Cuban Revolution. Guerra's work shows that the overstated differences between the Cuban Revolution and the Russian Revolution should not deter Cuban scholars from engaging with historiographies outside of their geographic areas of interest.

Soviet historiography proves that it is possible to write about the Cuban revolutionary experience from within. In many ways, the growth of Soviet historiography by Western scholars exemplifies the challenges and possibilities of writing histories without access to official archives for U.S.-based Cuban scholars. Before 1990, scholars of Soviet history worked with limited access to archives and were often navigating

\footnotetext{
${ }^{14}$ Ibid., 24.
} 
between affective worlds. Their approaches to writing about the Soviet experience, both Marxist and revisionist, caused rifts and left Sheila Fitzpatrick feeling "somewhat abandoned." 15 Yet this feeling of being an outsider was not new to Fitzpatrick, who grew up in a "leftist family in Anti-Communist Cold War Australia" and was accused of spying for the British government by Russian newspapers while she completed her dissertation research in 1968. Fitzpatrick's career inspired an edited volume, Writing the Stalin Era, about her life, experiences as a scholar, and contributions to Soviet historiography. Contributors to the volume described Fitzpatrick's "infatuation with the archives," and how this influenced her to engage different methodologies to tell the stories from below. She still encountered the archival silences, which became a formative experience. One contributor noted that "her (deceptive) appearance ... her 'little woman' appearance facilitated her coups in the archives." The physical description of Fitzpatrick does mention that it was more than her looks that helped; it attributes her success to "her intellectual caliber, her determination, and a certain wiliness." 16 However, as Fitzpatrick's account revealed, her research benefitted from her relationships outside of the archive. When she was told at the archives that they did not have reading rooms for foreign scholars, a friend "advised buying a bottle of cognac at the foreign-currency store and taking it as a present to the archive director ... this was the kind of thing fraternal

\footnotetext{
${ }^{15}$ Sheila Fitzpatrick, "Revisionism in Retrospect: A Personal View," Slavic Review 67, no. 3 (2008): 691. Also see Sheila Fitzpatrick, "Revisionism in Soviet History," History and Theory 46, no. 4 (2007): 77-91.

${ }^{16}$ See Kiril Tomoff, Golfo Alexopoulos, Julie Hessler, Writing the Stalin Era: Sheila Fitzpatrick and Soviet Historiography (New York: Palgrave Macmillan, 2011).
} 
foreigners were allowed to know, but not capitalists." ${ }^{\text {17 }}$ The affective bonds outside of the archive mitigated the challenges she faced in 1968 while conducting her research in Russia.

Talking about archival experiences, whether in Soviet Russia or Cuba, is necessary; not only do they reveal more than one door to the archive, they also push us to account for our subjectivity in our work. Researchers, especially those dreaming of the historical archive, travel to Cuba while imagining the possibilities of the archive, but are often left to find a way to negotiate their access. Unfortunately, we tend to ignore these experiences when we write the history of the Revolution. Bustamante identified the crux of the problem when he explained that writing about the Cuban Revolution is "ideologically and politically complex" when we take into account that "the process under analysis is theoretically active." His statement is also applicable outside of writing; we can see this in the varied experiences of field research as we experience the complex ideological and political processes while trying to gain access to information. In the first chapter, I reflect on the evolution of Cuban Studies within the United States through my research experiences in Cuba. I describe the physical conditions, from the heat to the archives, that quickly transform into bouts of tropical archive fever. The chapter underscores the value of applying the frameworks we use to study our subjects to our research, including the emotional journey to the archive. Historians need to acknowledge their subjectivity and their experiences in the archives. In this chapter, I use my research experiences to discuss the emotive regimes, communities, and repertoires one encounters,

\footnotetext{
${ }^{17}$ Sheila Fitzpatrick, A Spy in the Archives: A Memoir of Cold War Russia (New York: Palgrave Macmillan, 2013), 205.
} 
from the summer weather to institutional and everyday frustrations, in search of primary sources and the relationships outside of the archive that can help and frustrate researchers. These experiences shape the histories we write, and they also reveal that we are often closer to the subjects under study than we think as we engage in similar practices to navigate the Revolution's emotive regime. Ongoing conversations about the significance of the archive to history and historians between scholars within different areas of interest inspired this chapter.

The editors of Writing the Stalin Era describe the progression of Fitzpatrick's interests, mirroring the evolution of Soviet studies, "from institutional and bureaucratic history through social history to cultural studies of discourse and, most recently, emotions and everyday life." 18 Unfortunately, as Chapter One discusses, the progression of Cuban studies in these topics continues to face an archival roadblock. Cuban-focused scholars have yet to experience the watershed moment, in which the official red-tape dissolved along with the State, that benefitted Soviet historiography. However, this does not mean that scholarship about the Cuban Revolution cannot encompass a history of emotions within current archival limitations. Fitzpatrick herself began to write about Soviet experiences and feelings, albeit indirectly, in her dissertation about political culture. ${ }^{19}$ Like in Fitzpatrick's case, Cuban scholarship on political structures and institutions has evolved to include culture as a primary source of analysis, as reflected in the works of Louis Pérez and Lillian Guerra. These scholars also relied on emotive discourse analysis

\footnotetext{
18 Tomoff, Alexopoulos, and Hessler, 22.

${ }^{19}$ Sheila Fitzpatrick's dissertation research predates the discussions between social historians in the nineteen eighties that established emotions as a field of study.
} 
to unpack the meanings of power. But how can a focus on emotions and a comparative glance at Soviet scholarship help us to write a history of the Cuban Revolution after 1970? And where do we locate emotions within the limits of the Cuban archives? I propose a closer reading of Soviet historiography; this also helps us place the Cuban Revolution within a socialist world and not an exceptional experience. Anne E. Gorsuch and Diane P. Koenker note that "the socialist world was not a singular world," and a closer reading of the work by Soviet scholars reveals that, despite differences, there are parallels. As I wrote chapters two through four, I also referenced Soviet historiography. This dissertation mirrors the period under study by merging Cuban sources with practices pioneered in Soviet historiography to begin to understand what it meant to live and feel in socialist Cuba.

Chapter two focuses on the immediate response of officials to the emotive shift, underscored by the failure of the Ten-Million-Ton Harvest, to mass disillusionment that defined the second decade of the Revolution. Today, in a retrospective position, Cubans describe the five years after 1970 as the gray period; the phrase echoes the emotive blow of the harvest's failure on the Revolution's emotive regime. The reference to this period using the color gray connotes the emotions of disillusionment and dissatisfaction; it is also a reference to a repressive cultural policy. This cultural policy included increased state surveillance of artists and their work and was part of the emotive management by officials and institutions to sustain the Revolution as the emotive regime. ${ }^{20}$ Instead of focusing on the gray environment for artists, I turn my attention to the state's response to

${ }^{20}$ See Jorge Fornet, El 71: Anatomía de una crisis (Havana: Letras Cubanas, 2013). 
the national disillusionment of economic failure. The chapter shows how officials managed the Revolution's emotive regime by influencing and manufacturing a culture of celebrations using two examples: the Havana Carnival and Varadero's Music Festival. Carnival returned in the immediate aftermath of the Ten-Million-Ton harvest as a mass celebration of the

Revolution's achievements. Like in the Soviet case, Cuban mass celebrations promoted the accomplishments of the state; they became part of the official calendar to distract from the negative feelings that challenged narratives of progress and popular support. ${ }^{21}$ Varadero's Music Festival also made its return, quickly following the carnival season in 1970. These celebrations helped to dull the sting of popular disillusionment. Throughout the decade, officials continued to manage the regime by filling Cuban calendars with anniversaries that required a celebration or, at least, recognition in magazine covers, posters, and cultural programming. ${ }^{22}$ However, these paled in comparison to efforts deployed by officials in manufacturing the spectacle of carnival and the Varadero Festival. During the prolonged periods of scarcity in support of the Revolutionary Offensive launched in 1968, Castro had promised Cubans that they would make history with the harvest and Carnival would return. When the harvest flopped,

\footnotetext{
${ }^{21}$ See Malte Rolfe, Soviet Mass Festivals 1917-1991 (Pittsburgh: University of Pittsburgh Press, 2013); David L. Hoffmann, "Social and Cultural Unity under Soviet Socialism," in Stalinist Values: The Cultural Norms of Soviet Modernity, 1917-1941 (Ithaca: Cornell University Press, 2003), 146-83; David Brandenberger, "The Pageantry of Soviet Patriotism," in Propaganda State in Crisis: Soviet Ideology, Indoctrination, and Terror under Stalin, 1927-1941 (New Haven: Yale University Press, 2014), 98-119; Ali Igmen, "Celebrations in Soviet Kyrgyzstan during the 1930s," in Speaking Soviet with an Accent: Culture and Power in Kyrgyzstan (Pittsburgh: University of Pittsburgh Press, 2012), 83-97.

${ }^{22}$ Michael Bustamante discusses the effects of the anniversaries that dotted Cuban calendars in the early 1970s in his contribution to The Revolution from Within.
} 
Carnival became an indispensable tool for successfully managing the threats of an emotive shift in the aftermath of failure.

Chapter three captures the emotive repertoires of everyday life in Cuban magazines and the role of mass organizations in managing the emotive regime. The meaning of everyday life in socialist regimes has been the subject of much debate and discussion, from questions of the State's reach into the everyday to the notion of individual subjectivity. Soviet historians assert that everyday life "provided little refuge from the power of the state and that of well-intentioned experts and professionals...daily life became a site of overt ideological intervention." ${ }^{23}$ Print culture was a highly politicized medium controlled by the State; it penetrated the home and defined what it meant to live within the Revolution. A closer analysis of discourses in Cuban magazines reveals how officials had a hand in managing everyday emotions and practices. The magazines presented a socialist future through images of Soviet modernity and narratives of housing developments in the Cuban countryside but also the challenges of achieving these ideals, including hygiene, family relations, and customer service. The magazines of mass organizations exemplify what historian Rafael Rojas calls "the delicate balance between popular inclusions and exclusions." 24 The magazines were sites for the modernizing discourses and visions for Cuba's New Man in the seventies, but this vision did not include a female counterpart. While inclusive discourses portrayed women as

${ }^{23}$ See Choi Chatterjee, David L. Ransel, and Mary Cavender, Everyday Life in Russia Past and Present (Bloomington: University of Indiana Press, 2015).

${ }^{24}$ Rafael Rojas, "The New Text of the Revolution" in The Revolution from Within, 44. 
liberated through economic (labor) participation, the magazines also displayed

traditional, exclusionary discourses that challenged the characterization of Cuban women as a "Revolution within the Revolution." 25 The chapter shows how print culture worked as a repertoire of the emotive regime in its attempts to shape the emotional registers of everyday life. ${ }^{26}$

Chapter four describes the everyday activities which satisfied individual needs and official efforts to create a satisfied socialist consumer. ${ }^{27}$ Soviet and Cuban scientists engaged in research to define Cuba's socialist consumption in the seventies. The residents of Matanzas did not stay quiet. Inspired by the founding of the Organs of People's Power, matanceros attempted to effect change by appropriating the discourses of the emotive regime. Thus, the chapter reveals that Matanzas' provincial newspaper captured the birth of a public culture of complaint during the second decade of the Revolution.

In the conclusion, I briefly highlight the main findings of this dissertations while reflecting on how the emotive shift in the second decade had a lasting effect on everyday

\footnotetext{
${ }^{25}$ Fidel Castro declared that women were a decisive force in the Revolution. His opening speech at the founding meeting of the Cuban Women's Federation (FMC) on August 23, 1960, included the phrase "woman is a Revolution within the Revolution," which became a popular quote among the organization and the title of articles and books by the FMC. See Michelle Chase, Revolution Within the Revolution: Women and Gender Politics in Cuba, 1952-1962 (Durham: Duke University Press, 2015).

${ }^{26}$ Michael Bustamante describe the cultural climate of the seventies as a period in which "invocations of memory and history appeared everywhere, yet everyday existence could seem unremarkable, forgettableat best the evidence of a future already constructed and a prerevolutionary past left behind." See Michael Bustamante, "Anniversary Overload? Memory Fatigue at Cuba's Socialist Apex" in The Revolution from Within, 221.

${ }^{27}$ See Mark Steinberg and Valeria Sobol, Interpreting Emotions in Russia and Eastern Europe (DeKalb: Northern Illinois University Press, 2011).
} 
emotions in Cuba. I draw attention to emotions as indicators of change and tools to rethink the periodization of the Cuban Revolution. This chapter shows that there is much interdisciplinary work left for historians to do in the field of emotionology. 


\title{
CHAPTER I
}

\author{
Navigating Emotions: \\ Archive Fever and Cuban Studies
}

On November 12, 1970, Carlos Laceras wrote a letter to Jorge Serguera, Director of the Cuban Institute of Radio (ICR, for its Spanish initials):

Comrade: ${ }^{28}$

Perhaps these lines divert your attention, but I understand that as Director of the ICR, as a Revolutionary, as another member of this great family, that is the Cuban people, you will understand my concern, or perhaps that of thousands of other Cubans; either because we were born with these feelings, or because of the ideas that our Prime Minister has instilled in us during these years of Revolution. ${ }^{29}$

Laceras worried over the television broadcast of Varadero's International Music Festival in 1970. The festival was making a comeback since its last installment in 1967.

Newspapers promised an unprecedented event, bigger than the last. ${ }^{30}$ It is not clear how old Laceras was when he wrote his letter; he only identified himself as a member of one of Havana's Committees for the Defense of the Revolution (CDR). After his introductory appeal to Serguera's character as a Revolutionary and Cuban, Laceras declares that "some representatives of the Organs have once more forgotten about the people." The thought of these negligent representatives "even disturbed" his sleep. The letter places in

\footnotetext{
${ }^{28}$ Translations in this dissertation are mine, unless otherwise indicated.

${ }^{29}$ Letter, Carlos Laceras to Jorge Serguera, November 12, 1970, Box 358, MINCULT Archives.

${ }^{30}$ See Chapter 2 on the return of carnival and the music festival in Cuba during the 1970s.
} 
question the event's purpose, "what reasons exist[ed] not to invigorate the deserving people?" Laceras identified this deserving group as the working class of the country, who counted on the broadcast of the festival when their duties to their work impeded them from attending in person. He respectfully pled with Serguera to intervene for Cubans. Carlos Laceras was "sure that because of [Serguera's] status as a tested revolutionary," he would right this wrong "by all means." 31

Jorge Serguera most likely did not know more about Carlos Laceras than the CDR information he included in his letter; however, Laceras knew about Serguera. Serguera is often remembered as the man who banned the Beatles in Cuba; he also played a role in the Revolutionary struggle on the Island during the 1950s. After the triumph of the Revolution, he participated in the Revolutionary Tribunals as a public prosecutor. Later in his career, he acted as the ambassador of Cuba in Algeria and Congo. Some say that Serguera failed to give Fidel Castro complete information about the situation in Algeria, and that is how he ended up as the director of the ICR from 1966 to 1975 . Later in life and living in Miami, Serguera refuted the claim that he was against the Beatles on Cuban exile airwaves and stated that he was acting under the direction of others. Regardless of the validity of the rumors about Serguera's censorship, one thing was sure: Laceras recognized Serguera as a man with enough influence to solve the problem and bring Varadero's Music Festival to the masses.

Laceras' letter represents the challenges and possibilities of doing work in Cuban archives and writing histories of Cuba's revolutionary experience, specifically a history

\footnotetext{
${ }^{31}$ Letter, Carlos Laceras to Jorge Serguera, November 12, 1970, Box 358, MINCULT Archives.
} 
of emotions. This chapter focuses both on institutions and individuals that acted as the managers of the Revolution's emotive regime and on how these emotional managers continue to impact the field of Cuban studies today. I argue that researchers form an emotive community, which is, in part, defined by their collective experiences on and off the island. Scholars often encounter emotional managers while on their journeys into the Cuban archives; these experiences shape the histories that scholars choose to tell. U.S.based scholars must navigate between the emotional managers of the Cuban archive, institutional politics, and the historic exile community in Miami that also acts as an emotional force outside of the country.

Few historians address the issues of archives and sources in Cuba beyond an acknowledgment in their introductions about the challenges of doing archival work on the island. This lack of discussion about archival work in Cuba is problematic because we, as Cubanist scholars, need to share these experiences. More importantly, we need to recognize the role of our subjectivity and its impact on how we navigate the archive and its contents. In this chapter, I detail my personal experience gaining access to archives on the island while tracing the presence of emotive discourses in U.S. scholarship on Cuba. ${ }^{32}$ Throughout my account, I focus on the symptoms Jacques Derrida associates with archive fever: "the compulsive, repetitive, and nostalgic desire for the archive." 33 These symptoms are part of the emotional registers that shape our research. I reflect on the

\footnotetext{
${ }^{32}$ Martínez inspired scholars in other disciplines to explore the role of the archive in their writing. Bianca Premo gathered Latin American scholars to discuss their experiences in the colonial archive. See Hemisphere: A Magazine of the Americas 27 (Winter 2018), https://lacc.fiu.edu/hemisphere/volume27.pdf.

${ }^{33}$ Jacques Derrida, Archive Fever: A Freudian Impression (Chicago: University of Chicago Press, 1998), 91.
} 
evolution of Cuban historiography, the often-unstated role of emotions in it, and what this means for writing the history of Cuba's Revolution.

\section{CUBAN ARCHIVE FEVER}

Like Carlos Laceras, historians quickly lose sleep over the promise of archive holdings and the reality of limited accessibility. Access to sources and archives can turn scholars into superstars and myths in a field, especially if you write about Cuba after 1959. The possibility of uncovering unseen documents is why historians suffer from substantial side effects of archive fever. Bouts of excitement and hopelessness can wash over a researcher in a matter of minutes. Although it may sound dramatic, as scholars in the European context have noted, entering the archive does have its physical side effects. It has become a rite of passage, which leaves our hearts racing at the prospect of discovering new evidence.

When I started planning my dissertation research in Cuba, I considered myself in a privileged position; two weeks into my trip and several conversations later, I did not know how to feel. I had heard and read the stories of U.S. scholars and their challenges gaining access to archives on the island. But I thought myself different; after all, being born in Cuba and holding a Cuban passport, I did not need to follow the visa process of a foreign scholar. During June 2018, I traveled to Cuba full of ideas and hopes about the archives. I was confident that my relationship with the Cuban History Institute (IHC) and my Cuban nationality would make things a little easier than for previous scholars based in the U.S. I knew from the introductory notes of other scholars that access to archival materials dealing with the revolutionary period was not a given. My goal was to get past 
the reception desk and into the backrooms. In these backrooms, I was sure I would find the pieces of evidence I needed to answer my questions about Cuba.

One of my letters of introduction from the IHC was addressed to the Ministry of Culture's (MINCULT) archive. Via e-mail, Michael Bustamante advised me to go there first even if I only briefly visited that archive during my stay. I did not understand how important it was for me to go there first until later. I heeded his advice, and early the next day after my arrival, I walked to the new location of the archive, the former home of Juan Marinello. Before its move to the Marinello home, the archive resided in the National Library. ${ }^{34}$ Boxes remained in the National Library, and it seemed like moving would take months, maybe a year; the archivist worried about how they would fit the boxes in the small rooms of the Marinello house. I wondered why the Juan Marinello Institution's offices did not house the archives.

The small waiting room did not allow a lot of fresh air to circulate; I could feel the sweat trickling down the side of my face. The security guard took some pity at my red, over-heated complexion and moved the desk fan in my direction. I felt like the heat would consume me: was I suffering from archive fever? ${ }^{35}$ My imagination ran wild at the possibilities that lay down the corridor of the small house.

The only inconvenience during my first visit to the MINCULT archive was the summer temperatures; nothing appeared amiss. I even made it past the reception to a

\footnotetext{
${ }^{34}$ Juan Marinello Vidaurreta was a Cuban lawyer and author. After the Revolution, Marinello Vidaurreta assumed roles in the Cuban Communist Party and the National Council of Culture.

${ }^{35}$ On archive fever, see Carolyn Steedman, Dust: The Archive and Cultural History (Manchester: Manchester University Press, 2001).
} 
room with air conditioning, which served as the office for two staff members. I met with one of the archivists, gave her my letter and passport, and answered questions about my research interests and my institutional affiliations (on and off the island). After that meeting, I called the archive almost every day to ask about my paperwork. During the following weeks, I was told that not only did my approval depend on a signature from the director of the archive; it also needed the signature of Cuba's Vice Minister of Culture (who, the archivist explained, was traveling and then fired in those two weeks).

Throughout the process, I was repeatedly asked which university I attended as if I never gave the information during our first meeting. A family friend suggested that they were doing this on purpose.

By the second week in Havana, I felt desperate; it seemed that I would never see past the reception desk. At the height of my frustration, I reached out to anyone who could help, including a former vice-minister of culture. During a meeting at his home, the former state employee told me that he would help me. He also assured me that I was not the only one who experienced these things and that he had helped many a scholar gain access to sources. He suggested that the problem lay in how I approached MINCULT through IHC, that I should have first approached the Cuban Institute of Cultural Research Juan Marinello. The Cuban History Institute and Juan Marinello are both dedicated to research activities in history and culture, respectively. While they are similar in activities and services to researchers, they differ in organizational positions. The IHC is subordinate to the Central Committee of the Communist Party, and Juan Marinello is subordinate to the Ministry of Culture. Unbeknownst to my contact, I also walked to Juan Marinello's offices and asked why my approval process at the MINCULT archive was 
stuck in a bureaucratic loop earlier that day. The Marinello Institute replied that my IHC letter should have been enough. If I wanted to do it through them, it was a long process that included paperwork and fees. When I explained that I had already consulted with the international relations staff, the former minister implied that the problem was that I had not offered to pay.

Although it seemed like I had completely ruined my chances by not consulting the administrative delegation of the institutes and archives, the former minister appeared to have a solution for everything. After some insistence, he agreed to reach out to his contacts still working at the Ministry of Culture, and within twenty-four hours, he arranged for a meeting at the headquarters of MINCULT in Vedado. The former mansion turned into office was grand and undergoing renovations, which included a new, central air conditioning system. The walls had a fresh coat of paint; the light-yellow shade drew in the light. It was a stark contrast to the archives at Juan Marinello's house, and the thin, red wire radio antenna taped to the wall at the reception desk. There, I met with one of their international relations representatives who, upon review of my passport, told me that I was an "a-typical case." They were not sure if I had to pay for a research visa because I was born in Cuba. On my way back from the meeting, the former minister turned in his car seat and said that all I had to do was "follow the channels." For him, this included official and unofficial back channels to the archive. While his connections at MINCULT tried to find an answer to the a-typical situation, he offered a Cuban contact that could go into the archive and look for the documents I needed. The problem with following the channels set before me was that they went against my ethics, and they all required an exchange of money. 
Refusing to feel cornered into following another's methods, I persisted at the MINCULT archive. I walked to the small house once again. Once I gave my name at the reception desk, the archivist walked to meet me at the reception desk. She did not know what to say anymore. She tried to tell me a story about my presence coinciding with a change in vice ministers. Noticing that I was not going to walk away, she began to say things such as, "it is okay; you'll come back another time." Feeling the frustration bubbling up inside once more, I explained that as a student, I could not afford to make these trips if I was not even getting any work done. Caught off guard by my candor, she offered a solution: write a letter to the director of the archive. Gathering my thoughts, I grabbed a pen and paper. I often tell my colleagues that I wish I had taken a picture of that letter. I included a formal greeting to the director and explained that I had been waiting for a while for approval, but for one reason or another, it was still pending. Remembering that I received a last-minute request for a copy of the letter of introduction from my home institution, I decided I could make my request. I was unsure of my wording, but if they pushed me to my limits, I could try to do the same. My request: "I need a letter addressed to my university and the foundation board (which awarded me a grant) explaining why a letter of support from the Cuban History Institute is not enough to access the archives of the Ministry of Culture." I knew they could never write such a letter.

In my last attempt, I walked back to the MINCULT archive. I was ready to hear a hard no, but I wanted to have at least an opportunity to speak to the elusive director. I sat in the reception area and informed them that I was there to see the director (I had found out her name through other channels) and that if she had not arrived, I would wait. Tengo 
tiempo, I told the archivist as I re-adjusted my skirt. The security guard was trying to listen to the World Cup match through his radio. I could tell by the way he kept glancing at me that he found the scenario amusing. The receptionist was not too happy that I was listening in on her private calls. Flustered, she took out her cell phone and made a call. She passed the phone to me, introducing la directora. I was approved by the vice minister that morning, and within thirty minutes, I sat at a desk in the same office that I wrote my request waiting for the boxes.

My research journey with the MINCULT archives is not unique; many researchers experience a whirlwind of emotions when they deal with foreign institutions and their bureaucratic protocols. However, it is essential to acknowledge the feelings that often drive our actions. During moments of desperation and defeat, I came close to the precipice of engaging in extraofficial channels to gather my sources. At the beginning of my journey, when everything was going smoothly, my Cuban passport and past experiences in U.S. archives made me a passive subject. As I encountered the realities of researching in Cuba, my frustration pushed me to question everything and revealed that the path to the archive is not always straightforward. I had to be creative and imagine alternatives to move past the archival roadblock. At that moment, I wondered how other scholars navigated their access and if they encountered similar characters and offers.

\section{CUBAN STUDIES}

Anyone who has toyed with the idea of writing about the history of Cuba becomes familiar with the challenges of researching the country's archives quickly. These challenges range from funding and diplomatic relations to public transportation and poor 
archival conditions. The likelihood of not encountering one of these issues is dismal; researchers are likely to face three of the roadblocks mentioned above almost daily. There are many ways and reasons one can be denied access to the national archives, but there is also not a specific approach that guarantees entry. Instead, scholars must learn to navigate the political nuances of state officials and institutions while adapting to the realities of daily life in Cuba (such as difficulties in transportation or accessing the Internet). Although it can become a daunting experience, facing these challenges has pushed scholars and their work in new directions. A review of the evolution of Cuban studies in the United States shows how politics inside and outside the island have shaped scholars' research experiences and their scholarship.

For U.S. scholars, the most glaring obstacle to field research in Cuba is the political hostility between Cuba and the United States. After the Missile Crisis in 1962, during the 1960s, only one American scholar received special permission and an invitation from the state to conduct field research in Cuba: anthropologist Oscar Lewis in 1967. ${ }^{36}$ In an interview with James Green, historian Margaret Crahan describes the effects of the Cuban Revolution on Latin American studies in the U.S. during the 1960s as "mixed [...] the Cuban Revolution was discussed more about its impact on Latin America in general than on Cuba. I don't remember anyone who was working on Cuba per se. ${ }^{" 37}$ Although many U.S. scholars were interested in Cuba, Crahan's recollection

\footnotetext{
${ }^{36}$ See Oscar Lewis, Ruth M. Lewis, and Susan M. Rigdon, Four Men: Living the Revolution (Urbana: University of Illinois Press, 1977); Oscar M. Lewis, Ruth M. Lewis, and Susan M. Rigdon, Four Women: Living the Revolution (Urbana: University of Illinois Press, 1977).

${ }^{37}$ James Green, "Interview of Margaret Crahan: "We Cannot Remain Silent," We Cannot Remain Silent, Brown University Library, accessed October 12, 2019, https://library.brown.edu/wecannotremainsilent/megan-crahan/.
} 
captures the sixties as a pivotal moment in the evolution of Latin American studies. Crahan's current institutional home, Columbia University, founded the Institute of Latin American Studies (ILAS) in 1962, which coincided with the Cuban Missile Crisis. Led by historian Frank Tannenbaum, ILAS attracted scholars who would go on to write significant studies on Latin American history, society, politics, and culture (among these were Alfred Stepan, Jean Franco, Maxine Margolis, and Susan Eckstein). ${ }^{38}$ Crahan recalls how “'[t]he Cubans after 1961 weren't very welcoming. They were very suspicious. I went down the first time in 1973 [...] it was very rare even in 1973. At that point, they had begun to invite academics down.” For Crahan's U.S.colleagues, “it wasn't so much Cuba per se as the example of Cuba [which caught their attention]. We tended to focus on the countries that people were working on, so a lot was focused on Brazil." Cuba inspired scholars to think about the possibility of other revolutionary movements in Latin America. Nonetheless, the first decade of the Cuban Revolution remained in the periphery for most emerging scholars in the United States (a topic that many would eventually return to).

If the 1960s were a foundational moment for the field of Latin American studies (for example, the Latin American Studies Association was founded in 1966), the 1970s were the spark that pushed Cuban studies forward. In 1970 Cubans were working to gather a historic sugar harvest, the Ten-Million-Ton Harvest. Scholars watched, questioned, and debated the probability of Cuba reaching its goal of producing and

\footnotetext{
38 "About," The Institute of Latin American Studies (ILAS), Columbia University, accessed November 19, 2019, http://ilas.columbia.edu/about-ilas/.
} 
delivering Ten-Million-Tons of sugar to the Soviet Union. ${ }^{39}$ Economist Carmelo MesaLago, one of the few scholars at that time who predicted the harvest's failure, lamented the lack of sources and the unreliability of statistics from the Cuban government. Writing in 1969, Mesa-Lago acknowledged that Cuba was an "exciting research topic which appeals to social scientists throughout the world. ${ }^{40}$ The Hispanic Foundation in the U.S. Library of Congress was keenly aware of the academic excitement for Cuban topics. ${ }^{41}$ It used a grant from the Ford Foundation to host two conferences aimed at addressing the growing interest in Cuba and the challenges of meeting the demand from scholars. During a June 1968 meeting, scholars, librarians, and biographers exchanged ideas on how to grow library holdings of Cuba material. Two years later, the meeting focused on developing a strategy for U.S. universities, libraries, and collections to grow these holdings. ${ }^{42}$ In published recommendations from the second meeting in April 1970, the International Conference on Cuban Acquisitions and Bibliography explained that the conference "grew out of scholarly concern over the inadequacy of bibliographical

\footnotetext{
${ }^{39}$ See Chapter 3.

${ }^{40}$ Carmelo Mesa-Lago, "Availability and Reliability of Statistics in Socialist Cuba (Part One)," Latin American Research Review 4, no. 1 (1969): 53-91.

${ }^{41}$ The Hispanic Foundation in the Library of Congress was established in 1927. The foundation's efforts to collect more materials about Cuba was part of a growing interest in expanding bibliographies of Latin America. On the creation of the Hispanic Foundation, see Robert C. Smith, "The Hispanic Foundation in the Library of Congress," The Hispanic American Historical Review 19, no. 4 (1939): 564-71; on the work to expand bibliographic materials, see News from the Center, Spring 1970, vol. 7 (Washington, D.C.: Library of Congress, 1970).

${ }^{42}$ In the published conference report, editors recognize several U.S. academic institutions that had become "centers of Cuban research." The 1970 list identified the U.S. centers at the universities of Pittsburgh, Yale, Miami at Coral Gables, California at Los Angeles, and New Mexico at Albuquerque. Earl Pariseau, ed., Cuban Acquisitions and Bibliography (Washington, D.C.: Library of Congress, 1970), 8.
} 
information on Cuba since 1868."43 Academic institutions in the United States suffered from a lack of bibliographical information on Cuba; 1868 marked the beginning of Cuba's fight for independence from Spain. ${ }^{44}$ A grant from the Ford Foundation supported the publication of a summary of the discussions and the fourteen recommendations. ${ }^{45}$ The first recommendation addressed obstacles institutions and scholars faced. It included a call to action for the Government Relations Committee of the Latin American Studies Association to pursue the removal of past restrictions, the right to purchase Cuban research materials, and to promote scholarly exchange. However, the guidelines were subordinate to the United States' embargo of Cuba, which limited academic exchange.

The list included a recommendation for the Center of Latin American Studies at the University of Pittsburgh to publish a newsletter. The newsletter would not only promote the interchange of current holdings between institutions; it would also help scholarly exchange with Cuba. Conference contributor Carmelo Mesa-Lago, along with colleagues at the University of Pittsburgh, established the Cuban Studies Newsletter, "to provide a comprehensive and timely communication among those interested in Cuban studies." ${ }^{46}$ As a newsletter, Cuban Studies was a toolbox with "a classified bibliography and current information on research, travel, and academic programs." ${ }^{47}$ The newsletter

\footnotetext{
43 Ibid.

441868 marks the beginning of the Ten Years War in Cuba. On October 10, 1868, Carlos Manuel de Cespedes proclaimed Cuba's independence.

45 The summary of the conference was published and distributed free of charge.

46 “Preface," Cuban Studies 16 (1986), ix-x.

${ }^{47}$ Ibid, ix.
} 
grew to include a section of scholarly articles in 1975. By 1986, the sixteenth edition transformed into its modern-day format as a scholarly journal, Cuban Studies/Estudios Cubanos, also published by the University of Pittsburgh Press. ${ }^{48}$ Under the Jimmy Carter administration, U.S. regulations on Cuba travel loosened from 1977 to $1982 .{ }^{49}$ The evolution of the newsletter into an academic journal highlights the importance of access to the archive to scholarly production. Research activity in and surrounding Cuba was budding, and new research avenues were opening, although limited by the Cuban government's closure of archival records of the Revolution.

\section{CUBAN ARCHIVES AND HISTORIES AFTER 1959}

While Latin American and Cuban studies in the United States evolved and grew throughout the sixties and seventies, archival activity in Cuba stalled for a long time. In his contribution to The Revolution from Within, Cuban archivist Jorge Macle Cruz traces the evolution of archival practices within the Revolution. Macle Cruz describes the lack of a clear protocol across Cuban archives. In the sixties, Cuba's institutional archives and the Network of Historical Archives did not appear to adhere to the same protocols, if any. A single law passed in 1962, Law Number 714, addressed the functions of the National Archive and placed restrictions on the transfer of government documents. No other law succeeded Law Number 714 for thirty-nine years until Decree-Law 221. ${ }^{50}$ The 2001

\footnotetext{
${ }^{48}$ Jorge I. Domínguez, “Twenty-Five Years of Cuban Studies,” Cuban Studies 25 (1995): 3-26.

${ }^{49}$ See William M. LeoGrande and Peter Kornbluh, Back Channel to Cuba: The Hidden History of Negotiations between Washington and Havana (Durham: North Carolina University Press, 2015).

${ }^{50}$ Cuban Decree-Law 221, "Concerning the Archives of the Republic of Cuba," helped create a National System of Archives that ordered an organization of all archival materials at all levels (including mass organizations) and a process to transfer holdings to a final destination within the Network of Historical Archives.
} 
regulation reorganized the archival network. Macle Cruz considers the 2009 revision of the national system of archives, Decree-Law 265, the most significant law to date. Despite the law clearly stating that the National Archive is the repository for historical documents, certain Ministries have kept their archives closed to the public due to security concerns. In contrast, others, such as the Ministry of Culture, maintain their archives separate and do not send materials to the National Archive.

The slow evolution of archival regulations in Cuba affected the development of the historiography as well. When scholars made their way to the island in the early seventies, archives were operating without a standardized organization system. In addition to the cataloging nightmare, a large portion of the institutional archives was not beholden to an archival network. Scholars who visited the National Archive were limited to viewing colonial documents (those about the pre-1898 era in Cuba), which became more accessible and remained a topic of interest. When the Cuban government opened its archives, it did so slowly and tentatively. Most documents dealing with the Revolutionary period were inaccessible, and so the subsequent histories published by U.S. scholars tended to stop at the year 1959. Despite the growing travel to Cuba by U.S. scholars throughout the seventies and eighties, some fields appeared more restricted than others. In the case of economists, it was difficult to pinpoint the national repositories of hard data and trust their projections. Historians also encountered obstacles to identifying archives on the island and detailed holdings. Cuba's disconnected archives and the lack of cataloged documents from government organs made it challenging to write about Cuba's experience after the triumph of the Revolution. 
The work of Cuban-based historians also felt the impact of 1959, not only because of restricted access to the archive but also because of prevailing ideological currents. In the sixties, Cuban historians adopted a revisionist approach that underlined the historical continuities of Cuba's struggle for independence since 1868. These scholars were pandering to, and shaped, the Revolutionary ethos through their emphasis on continuity. Revisionist histories reframed the Revolution as the culmination of Cuba's historic struggles for sovereignty, consequently cementing the Revolution's roots in the national liberation movements of the late-nineteenth century. ${ }^{51}$ Inevitably, revisionists' efforts resulted in biased narratives, which became myths of the Revolution's inevitable triumph, as if it was written in the stars. When U.S. historians began to read the work of Cuban historians under the Revolution, they were left to unravel fact from fiction; this became the never-ending task for historians outside of Cuba. For example, reconstructions and meanings of José Martís image were one of the recurrent themes of the official historiography. ${ }^{52}$

\section{WRITING ABOUT EMOTIONS}

In the eighties, historians began to venture into a more nuanced analysis of Cuban national identity and its role in the history of the Cuban Revolution. In 1988, Louis Pérez's classic monograph, Cuba: Between Reform and Revolution, marked an important

\footnotetext{
${ }^{51}$ According to Louis Pérez history set "the standard ... by which sacrifice of the present is measured;" thus, history propped Revolution as a "total synthesis of the national experience." See Louis Pérez, "Toward a New Future, From a New Past: The Enterprise of History in Socialist Cuba," Cuban Studies 15, no. 1 (1985), 1-15.

${ }^{52}$ See Enrico Mario Santí, “José Martí and the Cuban Revolution,” Cuban Studies 16, (1986), 139-150.
} 
moment for the historiography of the Revolution outside of Cuba by including a chapter on the post-1959 period. The book was well received and continues to be an essential text for any scholar researching Cuba. At the time of its publication, reviewers praised Pérez's deftness in the organization of the book and its historiographical breadth. Yet, the reviews echoed one criticism: his cursory treatment of the revolutionary period in the final chapter, "Socialist Cuba." One reviewer called it the one flaw of the book, likening the chapter to “almost an epilogue." Another reviewer praised Peréz's cautious judgment, his "prudently orthodox" interpretation of the Cuban Revolution" and his "consistently restrained and unhistrionic" language. But to scholars like Christopher Abel something was missing: "it might leave the reader wondering why the Cuban revolutionary experiment had aroused so much passion and continues to do so." ${ }^{, 53}$ The general praise for Pérez's work underscored the gap in the historiography of the Cuban Revolution and the need for more work on the topic.

Whereas historians like Pérez published work that timidly dealt with the subject of Cuba's socialism, scholars in other fields, such as sociologists and anthropologists, grappled with the consequences of two decades of disconnect, especially from a U.S. perspective. In 1989, almost coinciding with Pérez's publication, scholars gathered in Halifax, Nova Scotia, for an international conference titled "Thirty Years of the Cuban Revolution: An Assessment." The meeting resulted in two edited volumes evaluating the

\footnotetext{
${ }^{53}$ Christopher Abel, "Reviewed Work: Cuba: Between Reform and Revolution by Louis A. Pérez Jr," Bulletin of Latin American Research 9 no. 1 (1990), 144.
} 
state of the Cuban Revolution as it entered a new decade. ${ }^{54}$ Sociologist Nelson Valdés's contribution, "Cuba in Transition: Crisis and Transformation," addressed the historical continuities of Cuba's political culture. ${ }^{55}$ According to Valdés, Cuba's political culture was primarily defined by "themes of personal duty, political morality, patriotism, and the historic mission of the nation." 56 He explained that despite a change in ideology and political leaders, Cuban moralisms remained the same because they were, historically, key elements of the island's political culture. Following Valdés's argument, Cuba's political culture structured Cuban's understanding of “social, economic, and political reality in dichotomous terms" before and after 1959. ${ }^{57}$ The Cuban Revolution triumphed by coopting political codes that dated as far back as the colonial period. Louis Pérez's book and Nelson Valdés's chapter exemplify how limited access to archives and contact with Cuban secondary literature led to an evaluative analysis of Cuba's Revolution. From national identity to political culture, both studies focused on the continuities, trying to understand the Cuban Revolution and its place within national tendencies that preceded the 1959 Revolution. Both scholars also relied on sources published before 1959 to build the bulk of their argument. The access to archival sources and Cubans living on the island after 1959 restricted the scope of their analysis.

\footnotetext{
${ }^{54}$ See H. Michael Erisman and John M. Kirk, Cuban Foreign Policy Confronts a New International Order (Boulder: Lynne Rienner Publishers, 1991), and Sandor Helbsky and John M. Kirk, eds., Cuba in Transition Crisis and Transformation (Boulder: Westview Press, 1992).

${ }^{55}$ See Nelson Valdés, "Cuban Political Culture: Between Betrayal and Death," in Cuba in Transition, ed. Helbsky and Kirk, 207-228.

${ }^{56}$ Nelson Valdés, "Cuban Political Culture: Between Betrayal and Death," in Cuba in Transition, ed. Helbsky and Kirk, 207.

${ }^{57}$ Ibid., 224.
} 
Shortly after the meeting in Halifax, the Soviet Union collapsed in 1991, and Cuba entered its worst economic crisis since the 1930s, the so-called Special Period. The decline of the economic situation in Cuba throughout the nineties added to the challenges faced by foreign scholars interested in the country. In 1993, under Bill Clinton's administration, the U.S. government expanded people-to-people contacts, including licensing travel to Cuba for educational purposes. ${ }^{58}$ Unfortunately, the history section of Cuba Studies did not show much hope for histories of the Revolution beyond economic assessments. Still, the section opened a window to work published on the island through reviews of the works authored by Cuban scholars and government organs. ${ }^{59}$ These reviews became more critical of a tainted retelling of history, especially in the texts that addressed events after the Revolution's triumph. A 1998 review of Nicolás Garófalo Fernández's Historia de la Revolución Cubana questioned the "low- or no-conflict presentation of competing views" between 1952 and 1958. In one glaring instance, the reviewer noted the inaccuracies in the portrayal of the counterrevolution in the Escambray Mountains. ${ }^{60}$ These inaccuracies in Cuban historiography pushed scholars outside the island to locate unfiltered oral histories.

Despite the focus on pre-1959 themes in Cuban historiography, the Clinton administration's people-to-people travel did have a positive impact on the growth of

\footnotetext{
${ }^{58}$ LeoGrande and Kornbluh, Back Channel to Cuba Cuba, 271-75.

${ }^{59}$ Samuel Farber, "Reviewed Work: The Cuban Revolution into the 1990s. Cuban Perspectives by Centre de Estudios Sobre América,” Cuban Studies 25 (1995): 264-66.

${ }^{60}$ Eloise Linger, "Reviewed Work: Historia de la Revolución Cubana by Nicolás Garófalo Fernández," Cuban Studies 27 (1998): 300-2.
} 
Cuban studies. In 1999, the journal Cuban Studies published two consecutive volumes that "demonstrate[d] once again the close interrelations between historical facticity and creative imagination. ${ }^{961}$ Cuban Studies also captured the rise of works on the exile experience. Social scientists, such as Alejandro Portes, Lisandro Pérez, Guillermo Grenier, and Alex Stepick, published collaborative projects on identity and the growing Cuban-American community. These books focused on Miami to showcase the impact of the exile community and its unique character as an epicenter for Cuban exiles and passionate debates about a Cuban future without Fidel Castro. ${ }^{62}$ The exile community is an emotive community that echoes (and at times fuels) U.S. - Cuba political hostility, which impacts U.S. scholars interested in the history of post-1959 Cuba.

Although the emotive components of the Revolution were a topic of interest, the early work of Pérez and Valdés showcases the trend of avoiding histrionic language. However, their terminology was emotive. In his analysis, Valdés was almost certain that the roots of betrayal dated back to the Spanish colonial system. The theme of betrayal reveals the affective character of Cuban politics. According to Valdés, political culture is rooted in the personal, as political relations "lack an effective neutrality." ${ }^{63}$ Betrayal and frustration were closely related and were a powerful combination in the political

\footnotetext{
${ }^{61}$ Enrico Santí, "Preface," Cuban Studies 28 (1999): xi.

${ }^{62}$ See Guillermo Grenier and Alex Stepick, Miami Now! Immigration, Ethnicity, and Social Change (Gainesville: University Press of Florida 1992); Alejandro Portes and Alex Stepick, City on the Edge: The Transformation of Miami (Los Angeles: University of California Press, 1993).

${ }^{63}$ Nelson Valdés, “Cuban Political Culture: Between Betrayal and Death,” in Cuba in Transition, 220.
} 
development of the nation during the twentieth century. ${ }^{64}$ Despite using themes or codes to label betrayal and frustration in the context of cultural politics, these are emotions.

Pérez also posed a question at the beginning of his text, suggesting the emotive elements of the Revolution: "[it] overthrew a repressive regime, to the general approval and acclaim of all... and the question arose immediately and persisted subsequently: why?"65 The piece was missing an exploration of the passions that the Revolution stirred inside Cuba and around the world.

Three factors impeded U.S. scholars of Cuba from taking part in the archival turn and the emotional turn in the historiography of the island: emotions, timing, and access. The triumph of the Revolution and the subsequent growth of the Cuban exile community fostered a highly emotional terrain which scholars (and anyone that wants to get involved with any Cuba topic today) must face. Thus, early scholars writing about the Revolution, such as Carmelo Mesa-Lago, Louis Pérez, Jorge Domínguez, and Nelson Valdés, purposely avoided emotive language to protect the ethos of their scholarship and navigate the emotional minefield of the Cuban exile community. They were also striving to appear as "serious scholars" before the non-Cuban academic community in the United States by avoiding affective language. By the eighties, when the history of emotions was established as an independent field in European and U.S. studies, Cuban scholars on and off the island were still focused on assessing and acquainting themselves with Cuba's

\footnotetext{
${ }^{64}$ Valdés cites the use of betrayal in political and intellectual initiatives during the 1920s, the popular overthrow of Gerardo Machado in 1933, and Castro's use of betrayal in his rhetoric during his time in the Partido del Pueblo Cubano (Ortodoxo). Ibid., 218.

${ }^{65}$ Louis A. Pérez, Cuba: Between Reform and Revolution (New York: Oxford University Press, 2015), vii.
} 
archival challenges. The breakdown in diplomatic relations, the persistence of the U.S. embargo of the island, and distrust of U.S. scholars in Cuba posed significant obstacles to the development of Cuban studies outside of the island.

Cuban historiography in the United States did not engage the growing field of the history of emotions until the 2000s. Over time, a slow but evident shift in the prevalence of emotions appeared in the work of scholars. However, even when feelings began to resurface in Cuban studies, they were not the focus of the budding historiography of the Cuban Revolution. In 2000, political scientist Damián Fernández called upon scholars to reconsider their aversion towards emotions and urged them to turn toward the politics of passion in Cuba. In his monograph, Cuba and the Politics of Passion, Fernández criticizes how political scientists have ignored the emotions in their analysis of Cuban politics. According to him, the politics of emotion became outdated quickly amongst political scientists resulting in its demise as an area of inquiry. Fernández's interest in "telling part of the story [that] is missing and telling it in an engaging way (i.e., with feeling)" led him to ask scholars "to bring the emotions back." ${ }^{16}$ Although Fernández was addressing scholars in his own discipline, his insight into the character of Cuban studies rang true across all fields: most scholars let the emotions go to focus on "rational interests. ${ }^{967}$

The challenges that Cuba posed for scholars during the nineties also pushed researchers to experiment methodologically. Sociologists and anthropologists grappled

\footnotetext{
${ }^{66}$ Fernández, Cuba and the Politics of Passion, 2.

${ }^{67}$ Ibid., 4.
} 
with the effects of scarcity and how Cuban's adapted to economic distress during the Special Period. Since the nineties, oral history projects have grown in popularity as well. Oral histories do more than capture the memories of a historical actor; they also convey the emotions that inspire both support and subversion. Emotions are an essential component in understanding sociocultural dynamics. They are central to the work of art and literary critics who question how artists express and invoke emotion through their work. Scholars in European and U.S. studies have spearheaded the scholarship of emotions by studying how peoples engage with various emotive elements. ${ }^{68}$ These studies analyze how groups and individuals appropriate, interpret, and express feelings about the political, cultural, and social framework in which they live. In the field of history, emotions complicate our understanding of societal norms and everyday life.

Fernández's work was not only important for its assessment of emotions in Cuba's political sphere but also initiated a new perspective in Cuban scholarship. The role of emotions in studies about the Cuban Revolution is more palpable in the scholarship of the last two decades. Historians such as Lillian Guerra, Michelle Chase, and Anita Casavantes Bradford feature the emotive components of the Cuban Revolution in their work. In Visions of Power, Guerra delved into the Revolution's culture of morality and its haphazard character. A palimpsest, the early Revolution's meaning was continually re-defined. Guerra's goal in writing the book was to understand "the grand

\footnotetext{
${ }^{68}$ See Peter Stearns and Carol Z. Stearns, "Emotionology: Clarifying the History of Emotions and Emotional Standards," The American Historical Review 90, no. 4 (1985): 813-36; Jan Plamper, William Reddy, Barbara Rosenwein, and Peter Stearns, "The History of Emotions: An Interview William Reddy, Barbara Rosenwein, and Peter Stearns," History and Theory 49, no. 2 (2010): 237-65.
} 
narrative of the Revolution in the language and euphoria of historic redemption." ${ }^{99}$

Guerra ably captured the feeling of euphoria through her uses of multiple primary

sources, which earned her monograph the 2013 Choice Outstanding Academic Title and the 2014 Bryce Wood Book Award from the Latin American Studies Association.

Praised for her "imaginative research," Guerra helped paved the way for a flood of new, imaginative scholarship on the Cuban Revolution, which accounts for the impact of the Revolution and Cuba's contested historical narrative through emotive expressions. ${ }^{70}$

\section{MIAMI: MERGING POLITICS AND EMOTIVE CURRENTS}

Florida's negative reputation in Cuban institutions is not surprising given Miami's demographics, particularly the presence of a vocal exile community. Miami Cubans hold polarizing views; migratory waves have only served to deepen generational divides, and most of the older, earlier generation of exiles does not tolerate any exchange with Cubaeconomic, cultural, or educational. ${ }^{71}$ These tensions can suffocate the progress of diplomatic and academic relations between the United States and Cuba. U.S. politicians are keenly aware of the influence of the Cuban-American community, which can and has played a deciding role in state and national elections. For example, in 1973, former U.S.

${ }^{69}$ Guerra, Visions of Power in Cuba, 36.

${ }^{70}$ This emphasis on the emotive character of the Revolution reinforces my basic argument that emotions are key to understanding the endurance of Cuba's revolutionary government (especially during its second decade). In the last twenty years, a noticeable shift in the historiography seeks to understand the emotions that moved Cubans to rebel, support, and imagine the possibilities of the Revolution. See Anita Casavantes Bradford, The Revolution is for the Children: The Politics of Childhood in Havana and Miami, 1959-1962 (Chapel Hill: University of North Carolina Press, 2014); Michelle Chase, Revolution within the Revolution.

712018 FIU Cuba Poll, School of International and Publics Affairs at Florida International University, https://cri.fiu.edu/research/cuba-poll/2018-fiu-cuba-poll.pdf. 
president Richard Nixon exhibited anxiety about any conversations or agreements with Cuba. He was recorded in his office, expressing that his only concern regarding any talks with Cuba was the mention of any normalization of relations “because I don't want the Cuban community to go up in a [...]." ${ }^{.72}$ For the hardline exile community, any exchange with Cuba only strengthens the Communist government; thus, academic work on Cuba can become tough if not impossible for scholars in Florida universities, especially in Miami.

It was not always so difficult to do research in Cuba if you studied or worked in Florida. Faculty at Florida International University (FIU) actively pursued research interests in the island throughout the nineties. In 1991, sociologist Lisandro Pérez helped to found the Cuban Research Institute (CRI) at FIU. That year, the institute co-sponsored the first FIU Cuba Poll which reported that $80 \%$ of Miami's Cubans favored tightening the embargo and 56\% "favor[ed] a United States invasion of Cuba."73 The poll surveyed 600 Cuban-Americans in Miami Dade and showed the divisions over the Cuba question that continue today. Over eight years (1991 to 1999), CRI recruited faculty associates from various disciplines across the university. Between the year2000 to 2006, CRI won editorship of Cuban Studies. ${ }^{74}$

\footnotetext{
${ }^{72}$ LeoGrande and Kornbluh, Back Channel to Cuba, 126.

${ }^{73}$ Guillermo Grenier, "The 1991 FIU Cuba Poll: Views on Policy Options toward Cuba Held by CubanAmerican Residents of Dade County, Florida," FIU Digital Commons (Florida International University), accessed October 13, 2019, https://digitalcommons.fiu.edu/cgi/viewcontent.cgi?article=1005\&context=cuba_poll.

${ }^{74}$ Cuban Research Institute, “Accomplishments," Florida International University, accessed October 30, 2019, https://cri.fiu.edu/about/accomplishments/.
} 
Miami exile politics eventually cut short the headway made by FIU through the Cuban Research Institute. In 2006, the state of Florida passed a Travel Act restricting academic institutions from funding travel to Cuba, whether from public or private sources. Later that year, the Faculty Senate for Florida International University filed court papers to challenge the Travel Act in the state of Florida. ${ }^{75}$ Restrictions on funding were not new for FIU faculty. A Miami Herald article revealed that FIU "prohibited using state money for Cuba travel" since 1988, which meant that researchers relied on outside grants. ${ }^{76}$ The plaintiffs gathered endorsements from scholars at other Florida universities to argue that the act violated First Amendment rights. The Travel Act is commonly referred to as the Rivera law, after Republican State Representative David Rivera, who served in the Florida legislature between 2002 and 2010. Rivera's support of the Cuba travel ban was unsurprising, given his "moral obligation to continue the cause of a free and democratic Cuba." ${ }^{, 77}$ Rivera's words echoed the growing impact of the Cuban exile community's on the southern state's politics since $1959 .{ }^{78}$ Florida International University and other universities across the state unsuccessfully attempted to overturn the bill, which hampered the development of Cuban studies in the state. Despite the FIU Faculty Senate's attempts, the Travel Act became a restrictive force in Cuban studies within Florida for a decade. The passing of the act disrupted the administration of

\footnotetext{
${ }^{75}$ In June 2006, the American Civil Liberties Union (ACLU) of Florida helped the FIU faculty file the lawsuit.

${ }^{76}$ Oscar Corral and Noah Bierman, "Schools Face Ban on Trips to Cuba," Miami Herald (February 28, 2006): B1.

${ }^{77}$ Oscar Corral, "Lawmakers Put Focus on Castro," Miami Herald (February 23, 2004): B1.
} 
university programs such as the Cuban Research Institute's travel grants for students and faculty. ${ }^{79}$ Without the possibility of funding travel to Cuba, some scholars specializing on the island were drawn to other states where universities continued to subsidize research in Cuba and could create programs for educational group travel and study abroad.

\section{EXPERIENCES ON THE ROAD TO THE ARCHIVE}

The ability to travel to Cuba and conduct lengthy research in 1996 helped Lillian Guerra's rise to prominence within Cuban studies. In the introduction to her book, Guerra describes how that first trip helped her reconnect with family, make new friends, and establish relationships with Cuban institutions. Although Guerra was a faculty member at the University of Florida when she published Visions of Power, for most of her academic career she was affiliated with universities in the northern U.S. I emphasize this detail because a scholar's academic affiliation is a deciding factor when asking to enter the Cuban archives. Before I arrived in Cuba, a colleague with contacts in the National Archive explained what was told to him: the name of the university did not matter when you came from Florida, and it was an automatic red flag. Some factors could ease the concern over a Florida affiliation, but only one could automatically get you off the Cuban bureaucratic hook: research topics unrelated to the Revolution. Unfortunately, I was a Cuban émigré, from an academic institution in Florida, and my research interest had everything to do with the Cuban Revolution.

\footnotetext{
${ }^{79}$ See FACULTY SENATE OF FLORIDA INTERN. UNIV. v. ROBERTS. Case No. 06-21513-CIV.
} 
One of the reasons I chose to study at Florida International University was its location; it made no sense to me to go North to study a country in the South. I was aware of the obstacles, such as the possibility of unforeseen travel restrictions from the mercurial relationship between Cuba and the United States. Fortunately, I did not have to worry about state travel restrictions to Cuba by the time I entered the doctorate program at the University. One year into the program, the Obama administration reestablished diplomatic relations with Cuba. ${ }^{80}$ The push toward "normalization" between the two countries had an immediate impact on my cohort and our funding sources. At FIU, beginning in 2016, a large portion of the Tinker Foundation field research grants funded travel to Cuba. Topics and disciplines ranged from history to biology. The Cuban Research Institute also provided support for research in Cuba.

The atmosphere in academic circles hummed with enthusiasm, and the possibilities of Cuba attracted cross-disciplinary interests. A quarterly cover on The American Historical Review captured the surge of Cuba in the academic imaginary: two porcelain figures of schoolboys representing the Soviet Union and Cuba in an embrace. The accompanying article by Anne Gorsuch discussed how the reception of Cuba in the USSR reflected Soviet attitudes during the 1960s about their 1917 Revolution. ${ }^{81}$ Gorsuch illustrates how many Soviet citizens" "romantic passions" for the Cuban Revolution transformed into disillusionment at the end of the sixties. While discussions surrounding

\footnotetext{
${ }^{80}$ Diplomatic relations were reestablished on July 20, 2015.

${ }^{81}$ Anne E. Goprsuch, "“Cuba, My Love': The Romance of Revolutionary Cuba in the Soviet Sixties," The American Historical Review 120, no. 2 (2015): 497-526.
} 
the Soviet legacy in Cuba began to garner scholarly attention before Obama announced normalization, the announcement made Cuban studies an attractive topic for many scholars. $^{82}$

When I was awarded a Tinker travel grant in 2016, I knew that I had an opportunity to establish the institutional relationships that would help me in future research trips to Cuba. During my week-long exploratory visit to Cuban archives, I continually asked people how I could become affiliated with the Cuban History Institute (IHC, for its Spanish initials). The information reached me in pieces. While one person gave me the names of the staff, another identified the person I needed to talk to regarding affiliations between the IHC and foreign scholars. When I called the IHC during that research stay, I was unable to get ahold of the international relations representative. I was fortunate that my open inquiry into the IHC was well known to the family in the house I stayed at during my visit. Luisa, the namesake of the casa particular (a privately-owned guest house), ran into an old acquaintance two days before my departure. In casual conversation, he mentioned his father, at the time the director of the IHC. Luisa did not hesitate to ask him for a favor: could he facilitate my introduction to the IHC? Because of their previous business relationship, the director's son considered Luisa a trustworthy person; not that Luisa did not throw an ay chico (“oh, boy”) or hazme el favorcito ("please help me out"). I did not realize it at the time, but I benefitted from the politics of lo informal.

\footnotetext{
${ }^{82}$ Most of the published analysis of the Soviet-Cuban relationship comes from literary scholars; in recent years, this discussion has expanded to include artwork produced on the island. See Jacqueline Loss and José Manuel Prieto, Caviar with Rum: Cuba-USSR and the Post-Soviet Experience (New York: Palgrave Macmillan, 2012). Loss followed the edited volume with Dreaming in Russian: The Cuban Soviet Imaginary (Austin: University of Texas Press, 2015).
} 
Lo informal, which some call sociolismo, is birthed by daily hardships and scarcity in post-revolutionary Cuba. Personal relationships of affection cement informal spaces and practices to alleviate the shortcomings of the state in establishing reforms and bureaucratic efficiency. ${ }^{83}$ By the time I returned to Miami, I held in my hand a small piece of paper with the handwritten contact information for the IHC President and his son's first name. Back in Miami, I drafted an introductory letter to the director asking for his guidance in establishing an academic affiliation to conduct future research. Although I quickly mentioned his son's name to explain why I was contacting him directly; I did not ask for more than the proper protocol within the IHC. My confidence in my ability to do archival research soared after securing an institutional affiliation in Cuba.

In my efforts to gain entrance to the archives, I both relied on and was put-off by lo informal. By the time I was ready to return to Cuba in 2018, I reached out to the IHC and confirmed the documents I needed before I could receive letters of introduction. When I arrived at the IHC offices, I was told that my Cuban passport and the length of my stay exempted me from paying fees (I divided my trips into two, month-long stays). If I had stayed longer than a month, then I would have had to pay a fee similar to a research visa; the Cuban passport worked in my favor. This was not always the case. My experience with MINCULT proved that there was more to archival research than presenting official documents. I am also not clear if the IHC's waiving of fees was an official rule because when I explained this logic at the Juan Marinello Institute, I was met with a furrowed brow and a shake of the head. I continually relied on the duality of my

${ }^{83}$ See Fernández, Cuba and the Politics of Passion, Chapter 8. 
identity as a Cuban born on the island and a scholar to navigate meetings with institutions. If the opportunity presented itself, I regularly engaged in mundane conversations that allowed me to display my Cuban identity before I showed my passports. ${ }^{84}$ Establishing a rapport with staff before showing my status as a U.S.-based scholar often resulted in positive outcomes. I firmly believe this is one of the reasons small fees were waived, or I was asked to pay in Cuban pesos. The older generation at government offices often softened their stance and exclaimed pero tú eres cubana ("but you're Cuban").

The positive exchanges created a false sense of security; I should have anticipated that not everyone would see me as just Cuban. While I waited for word from the MINCULT archive, I became a regular at the National Library. This was familiar territory, and I encountered the same staff at the circulation desk that helped me during my first trip. I engaged in a casual conversation with one of the staff members and asked him why he kept using the formal usted instead of the informal tú Cubans use every day. Without missing a beat, the young man looked at me and said, "you're not Cuban; you're different." I could not help the uncomfortable feeling that settled in my stomach; it was a wake-up call. The conversation at the National Library's reading room opened my eyes to the reality that I could not walk into the MINCULT archives as a Cuban because on paper I was a U.S. scholar. Even more worrisome was that I came from a Florida university located in Miami. Realizing that I could not appeal to the MINCULT staff through a display of cubanidad ("Cubanness") led me to seek help. That is how I ended up in the

\footnotetext{
${ }^{84}$ I was asked for my Cuban and U.S. passport.
} 
living room of the former MINCULT official on the verge of tears from the frustration of not knowing how to plead my case.

When identity as a foreign scholar overshadowed my cubanidad, lo informal quickly became a dangerous space. I was faced with a choice to pay a musicologist to enter the archive via unofficial channels or stay stuck in my bureaucratic loop. I had to imagine new approaches to the problem if I wanted to keep my academic integrity. Engaging in lo informal helped me when I needed an introduction to the IHC, but it also set before me choices that I was not comfortable making. That is when I chose to appeal my case via lo formal.

\section{EMBRACING THE SILENCE}

Historians and archivists are sensitive to silences and the dust that gathers on documents hidden from view. These conditions are not only descriptive of the physical state of the archive. Archival silence is a term used to refer to the documents that should be a part of the archive, but because of historical events, actors and movements are left out of the official records. ${ }^{85}$ Scholars rely on oral histories to fill the silences of the archival record; this practice has become appealing to those writing about the Revolutionary period in Cuba. However, I want to challenge scholars to push past the silences and the dust. We need to engage in interdisciplinary conversations about the road to the archive and how to write histories from what we perceive as silences.

\footnotetext{
${ }^{85}$ See David Thomas, Simon Fowler, and Valerie Johnson, The Silence of the Archive (Chicago: NealSchuman, 2017).
} 
When I wrote the letter to the director of the MINCULT archives, I knew I was taking a gamble. I did not realize that I was also engaging in a joint practice stimulated by the post-1959 emotionological shifts in Cuba. ${ }^{86}$ My actions mirrored Carlos Laceras when he wrote the letter to Jorge Serguera. Although the reason for our sleepless nights differed (he worried about access to a popular festival and me about access to the archive), we engaged in a similar approach. Laceras and I had a shared belief in the power of writing a letter addressed to an authority figure in Cuba. Laceras wrote a letter that reflected the emotional regime of the Revolution. He understood which emotive language would appeal to the director and his revolutionary ethos. I wrote a letter as a member of an emotional community, U.S. based scholars, just beginning to learn how to navigate my feelings. Although Laceras' letter appeared in a file bursting with documents on the organization of the Varadero Music Festival, I almost did not pay attention to it because it was filed with duplicates of festival press notices. I took notes thinking that it would add to the narrative of the festival and its popularity. Still, the letter turned out to be my first example of the Revolution's emotional communities.

I discovered the Girón archive after encountering another bureaucratic loop at the provincial archives in Matanzas. I was trying to access the official records of the first Poder Popular organization, but the boxes were undergoing a cataloging and archival transfer without an end date. While talking to staff at Matanzas' MINCULT offices, one of the lead investigators suggested I visit the newspaper's offices. Via the MINCULT staff in Matanzas, I met with the newspaper's director and gained immediate access to

\footnotetext{
${ }^{86}$ See Introduction.
} 
their archival holdings. Although it was small and lacked air conditioning and proper lighting, the archive was well preserved. In the newspaper archives I almost missed the Apartado (An aside) because I was intent on tracing the sequence of events leading up to the 1970 festival season. Reading through the newspaper became a chore when I could not find the information I imagined to be there initially. I stopped looking for the festival and started to scan the pages systematically. I became so accustomed to the layout of the paper, that when the first Apartado appeared I stopped mid-page flip and began to read.

The practice of writing to public officials in Cuba to address administrative inadequacies became a routine for Cubans in the seventies. The Revolution promoted an ethos of self-criticism but also of accountability. When the Ten-Million-Ton sugar harvest failed, the rhetoric of the state and officials stressed the need for Cubans to become more engaged and hold each other accountable to ensure that everyone was doing their part. Written complaints transformed into a public practice by 1975 , especially amongst a population that experienced a soar in education during the sixties. In Matanzas, the archives of the provincial newspaper, Girón, reveals the popularity of public letters. The opinion section, Apartado 133, began with an open call for locals to engage in state-building by sharing their concerns in a public forum. Throughout the seventies, the Apartado featured over four hundred entries. Most of these opinions arrived at the newspaper as letters, which the newspaper staff would print completely or edit to present each concern. Although these letters underwent some editing, they also taught people how to structure their concerns in a way that caught the attention of state organs and elicited, at the least, a public reply via the Apartado. When I wrote to the 
director of the archive, I unknowingly replicated the strategies adopted by Cubans during the second decade of the Revolution. ${ }^{87}$

\section{“TEMAS: CULTURA, IDEOLOGÍA, SOCIEDAD”,88}

In 2017, the Cuban magazine Temas dedicated its third installment of the year to the state of Cuban studies outside of the island. Magazine editors noted that the issue answered a question posed in 1995 by the publication about the state of the field outside of Cuba. The effects of political hostilities not only appeared in the expert reports, but they were also evident in the editorial note. In the opening note, the editors expressed that the efforts behind this publication were an attempt to bring some "balance" to the study of Cuba. It noted that five years before the magazine asked the question about the state of Cuban studies, Florida International University hosted a conference "only with participants from the United States." Furthermore, the 2018 conference co-sponsored by Temas and John Jay College at The City University of New York in Barcelona, "differed from the meeting in 1990, because this time various researchers from the island were invited to debate the ideas." 89

While Cuba-based scholars were not included in the 1990 conference, political hostilities and a lack of access to the U.S. scholarship problematized their participation. The conference, hosted by Florida International University’s Latin American and

\footnotetext{
${ }^{87}$ See Chapter 4.

${ }^{88}$ Full title of Cuban magazine Temas, noting the focus of the issue: the discussion and dissemination of information about Cuban social sciences, humanities, arts, political theory, and ideology.

89 Temas 91-92 (2017).
} 
Caribbean Center, echoed conferences of the past. Unlike the 1989 Canadian conference, the meeting at FIU focused on highlighting issues that plagued the field in the United States. Damián Fernández invited U.S. scholars to a conversation that turned into a critical self-analysis of subjectivities in Cuban studies. In the resulting edited volume, Cuban Studies since the Revolution, Fernández stated the crux of U.S.-based scholars issue: "Although as a community we have shared a common fabric of issues, and at times methods, we are more like an unpatterned quilt than a tapestry... Cuban studies has been prone to controversy and polemics. Cubanists have been more successful in talking past rather than with each other." ${ }^{, 90}$ The conference helped to bring together scholars in an honest discussion about the theoretical disputes and the future of interdisciplinary fields. The section on the state of Cuban bibliography in the U.S. revealed that issues of access to sources and Cuban scholarship remained. Peter Johnson commented that "the quality of future research depends in large part on heightened awareness of the importance of better collaboration among all individuals and institutions directly and indirectly involved with the research process. Understanding the nature of changes and identifying the potential for significant shifts in policies demands flexibility and a high degree of resourcefulness." Johnson wrote his assessment based on three trips to Cuba, between 1979 and 1987, and his exchanges with Cuban scholars during those trips and at conferences outside of Cuba; he did not describe his exchanges. ${ }^{91}$

\footnotetext{
${ }^{90}$ Damián J. Fernández, ed., Cuban Studies Since the Revolution (Gainesville: University Press of Florida, 1992), 2-3.

${ }^{91}$ Peter Johnson, "Toward the Rectification of Shortfalls and Production Constraints Affecting Cuban Research: Bibliography for the Year 2000," in Cuban Studies since the Revolution, 288.
} 
Over twenty years after posing the question, Temas published U.S. scholars' perspectives on the state of Cuban studies, the challenges, and themes for future work. Like in the FIU conference, contributors carefully outlined the evolution of Cuban studies in fields such as history, sociology, literature, economics, and anthropology. The numerical data and conclusions revealed that scholars inside and outside of Cuba faced similar roadblocks in regards to archival holdings or the lack thereof; most of the field's periodization of the Revolution resulted in a higher volume of information from the nineties and an absence of studies on earlier decades of the Revolution. Despite the political undertones, the exchange between U.S. and Cuban scholars showed that even with the geographic and political distances, both groups were in a similar position when it came to the challenges of writing about Cuba's Revolution from the archive. Unfortunately, due to the context of the publication, scholars filtered their critical analysis of the state of Cuban archives. They did not discuss the experience of researching Cuba beyond lamenting the lack of access to sources. I propose that only by sharing research experience and its emotive components, will we begin to understand how Cuban studies in and out of Cuba have yielded a wealth of scholarship that continues to feel unbalanced. We must acknowledge the contexts (emotionology) that limit us and can also help us write the history of the Revolution from within. ${ }^{92}$

\section{CONCLUSION}

In interviews, Jorge Serguera claimed that his actions within the ICR were intended to bring positive changes. Those who worked with Serguera during his tenure at

${ }^{92}$ See Bustamante and Lambe, eds., The Revolution from Within. 
the ICR believe that his presence left a trail "worse than a category five hurricane." 93 Despite his reputation amongst ICR employees, Serguera's status as a revolutionary prevailed in the public eye. In his letter to Serguera, Carlos Laceras adopted the revolutionary ethos to achieve his interests. His allusion to a feeling that bound him and Serguera allowed him to point out the institutional inadequacies which tormented his mind. It is unknown if Laceras ever received a reply to his passionate letter or if the broadcast issue was resolved; his letter sits amongst the official documents of the festival housed in the archives of Cuba's Ministry of Culture. Laceras's letter and Serguera's history as an emotional manager of the regime encapsulate the intricacies of navigating the Revolution's emotive regime to this day.

This chapter reveals that emotions also impact the work of scholars. U.S.-based scholars are part of an emotional community accustomed to navigating a multitude of emotional registers both inside and outside of the archives. Although scholars are required to appeal to institutions to gain entry into the archive, the letter of introduction does not necessarily guarantee access. Scholars encounter a broad array of characters, from the receptionist to the archivist, who act as the gatekeepers and emotional managers of scholars' experiences. Encounters with the managers of the emotive regime continue to have an effect on scholars, their work, and the evolution of Cuban Studies.

\footnotetext{
${ }^{93}$ In a personal blog collecting memories and experiences in Cuba, Eugenio Antonio Pedraza Ginori details his experience working in the ICR with Jorge Serguera. In the entry he describes Serguera as "presumptuous" and using the offices of the ICR as "a place to hang out watching movies, playing chess and flirting with women, if possible young." Pedraza was responding to the interviews of Serguera published in a book, where he described the ICR before his arrival as a place "lacking structure and organization" where men in power took advantage of young women. See El Blog de Pedrazaginori. On the Serguera interview, see Ernesto Juan Castellanos, John Lennon en La Habana: With a Little Help from My Friends (Ciudad de la Habana: Ediciones Unión, 2005).
} 
It is difficult to pinpoint the exact moment in which archive fever overwhelms a scholar. Once the fever sets in, symptoms include loss of sleep and an overactive imagination. Scholars interested in Cuba often suffer from a peculiar version of the illness: tropical archive fever. The heat of the island draws researchers in like a siren song. When travel to Cuba is feasible, the researcher begins to hallucinate about the contents of the archive. Without a clear path, the experience quickly rouses the emotions. The metaphorical heat that drew the scholar becomes a suffocating presence at every turn. It is not easy to deal with closed archives with the weather, and in a feverish daze, researchers can easily fall into questionable practices.

The symptoms of tropical archive fever are visible in the evolution of Cuban studies. The events leading up to the 1959 Cuban Revolution sparked much scholarly interest; the field of Cuban studies in the United States evolved alongside a rise in academic activity and the creation of centers for the study of Latin America during the 1960s. During the seventies, when U.S. scholars made it to the island in small numbers, their research stories infected others with curiosity. That curiosity is vital to the sustained growth of Cuban studies in the United States. Also notable is the growth of the Cuban American community in Miami, which has inspired scholars to write about the politics of exile but has also thwarted researchers' efforts to understand the Cuban experience outside and inside of the country.

The road to the archive is not easy for any scholar conducting field research outside of their home countries. We all must learn to adapt to different forms of bureaucratic procedures, not to mention the historical events and archival practices that 
have preserved important documents and created palpable silences as well. For scholars suffering from tropical archive fever, it is important to find comfort in that they are not alone. But we cannot get too comfortable with this knowledge; instead, we need to be more open about our symptoms and the ways we have remedied the bouts of tropical archive fever. Often, from within the silence and the dust of the archive, scholars are ceaselessly taking imaginative approaches in finding and writing about their sources. ${ }^{94}$

${ }^{94}$ In an article about the colonial archives in Latin America, María Elena Martínez describes the challenges of documents in the archive and the possibilities in approaching these from different angles. While Martínez focuses on the performative interpretation of the archive as a contrast to scholarly approaches, she makes a call for scholars to acknowledge "the role of the imagination in historical reconstruction." Imagination is present throughout the scholar's journey to creating a written piece. We imagine our topic, the sources, the archive, and the people who will read the final product. However, we do not credit our imagination for the final product in efforts to lend credibility to our work as serious and objective scholars. See María Elena Martínez, María Elena Martínez "Archives, Bodies, and Imagination: The Case of Juana Aguilar and Queer Approaches to History, Sexuality, and Politics," Radical History Review 1 (October 2014): 159-182. 


\section{CHAPTER II}

Manufacturing Joy:

The Return of Popular Festivals in 1970s Cuba

"I believe that the Revolution is a great celebration of the people. And if it is a genuine revolution, it will never lose its festive character: its joy, its enthusiasm, the collective spirit of the popular festivals. We know that because we have seen it in our people." -Armando Hart Dávalos in Cartas sobre la mesa (1984)

In 1983, Cuba's minister of culture, Armando Hart Dávalos, sat down for an interview with reporter Luis Báez. ${ }^{95}$ The interview was published as a book the following year by the Cuban editorial Letras Cubanas, titled Changing the Rules of the Game. According to the synopsis, the interview, conducted in the aftermath of Hart's European tour, outlined Cuba's cultural path with an emphasis on "the need to change the rules of the game so as not to fall into the trap of manipulators of consciences and professionals of frivolity."96 Báez and Hart's interview responded to criticism abroad regarding the Cuban government's treatment of artists and its effect on cultural development. ${ }^{97}$ The questions in the interview were straightforward and touched on controversial topics, such as the artistic exodus; however, the answers were not as upfront and lacked the selfcriticism insinuated in the synopsis. Questions regarding the treatment of intellectuals

${ }^{95}$ Luis Báez helped found he Cuban daily newspaper Granma.

${ }^{96}$ Luis Báez, Cartas sobre la mesa (Mexico, D.F.: Siglo Veintiuno Editores, 1984).

${ }^{97}$ In 1971, the Padilla Affair, an international scandal involving poet Heberto Padilla, divided intellectuals around the world as it exposed the Cuban government's repressive measures against artists. Publishing such an interview with Hart in 1983 attests to the long- lasting effects the Padilla Affair had on the country's international reputation. Padilla's name is never brought up in the interview; instead, when asked about dissident artists Hart chose to focus on those writers, poets, and musicians who stayed in Cuba and within the Revolution. 
served as an opportunity for Hart to redirect the reader's attention to the successes of the Cuban Revolution; he emphasized the festive character of the Revolution. According to Hart, "Cuba could not be more Caribbean." He described the character of the Revolution as "very serious," yet it was an endeavor carried out with joy. Hart associated the festive nature of Cubans and the work of the Revolution as one, emphasizing that "we have great popular festivals [...] where everything is joy and enthusiasm: there are parties in all the localities of the country, and all have a genuine Caribbean spirit." 98 The description of a serious but joyful revolution was more than a claim about Cuba's Caribbean character; it was also the result of an emotive shift in the aftermath of the failure of the Ten-MillionTon-Harvest.

The popular enthusiasm for the tenets espoused by the Revolution was visible in the early sixties. It influenced people's participation in mass rallies, public trials, and the voluntarism that aided the success of social welfare campaigns, such as the Cuban literacy campaign in $1961 .{ }^{99}$ Lillian Guerra concluded that one word encapsulated the revolutionary culture of the sixties: fidelismo. ${ }^{100}$ Fidelismo became the prevailing emotive current of the sixties within the Revolution's emotive regime. It helped to establish modes of expression as a cultural religion fashioned after the words and images of Fidel Castro. A unique component of the early years of fidelismo was the idea of

\footnotetext{
${ }^{98}$ Luis Báez, Cartas sobre la mesa, (Mexico, D.F.: Siglo veintiuno editores, 1984), 67.

${ }^{99}$ For more on the literacy campaign see Ana Serra, The "New Man" in Cuba: Culture and Identity in the Revolution (Gainesville: University Press of Florida, 2007), Chapter 1.

${ }^{100}$ Like Andrés Suárez's castrismo, which Damián Fernández uses to analyze the emotive currents of the Cuban Revolution's political culture. See Damián Fernández, Cuba and the Politics of Passion, 67.
} 
revolución con Pachanga/revolution with celebration. ${ }^{101}$ In the 1962 Carnival, the National Council of Culture used the "traditionally black environment" as a vehicle for advancing the vision of a racially inclusive society. However, as fidelismo developed a rigid rhetoric surrounding racial inclusion, the concept of revolución con pachanga as a distinctly Afro-Cuban expression became problematic and lost official favor. ${ }^{102}$

Traditional celebrations, such as carnival, continued to draw crowds to the streets in the sixties. However, the meaning of these celebrations would change as the nation prepared to complete its historic task of a record-breaking sugar harvest that, if accomplished, promised to boost Cuba's economy and, in turn, standards of living.

At the end of the first decade, officials depended on fidelismo to rally behind the ideals of the Revolutionary Offensive, a political campaign that scholars liken to China's Great Leap Forward. The Revolutionary Offensive was a vehicle for officials to socially engineer the New Man described by Che Guevara in his writings. It marked the beginning of the second decade and affected all aspects of society, including the nationalization of small businesses in 1968. The main goal of the offensive was the production of ten million tons of sugar. This task not only required the participation of all Cubans, but it also promised to "fight selfishness and individualism." ${ }^{103}$ Unbeknownst to

\footnotetext{
${ }^{101}$ Che Guevara expressed that the Revolution acquired a festive character in the 1960s. He used the word pachanga to describe the atmosphere, or "party ambiance" of those years. See Robin Moore, "¿Revolucion con Pachanga? Dance Music in Socialist Cuba," Canadian Journal of Latin American and Caribbean Studies / Revue Canadienne Des Études Latino-américaines et Caraïbes 26, no. 52 (2001): 151-77.

${ }^{102}$ See Chapter 1. Also see Lillian Guerra, Visions of Power, Chapter 4.

${ }^{103}$ See Yinghong Cheng, Creating the "New Man": From Enlightenment Ideals to Socialist Realities (Honolulu: University of Hawai'i Press, 2009).
} 
officials this campaign would set the tone for the second decade as a period of disillusionment.

Beginning in 1968 and following the rhetoric of the politics of passion, the Revolutionary Offensive required individual sacrifice or giving up individual interests. Between 1968 and 1970, the Revolution's emotive regime placed achieving production goals above everything. The harvest was the ultimate, collective sacrifice; the state mobilized all production sectors, recruited the labor of high school students, changed the workday to four hours, and imposed an eighteen-month calendar year. Despite heightened controls and surveillance, the effects of emotional suffering led to divergent behaviors in daily life. The promise of economic success did not erase the scarcity in state-owned stores. It also did not help that the campaign sought to eradicate street businesses that helped alleviate the effects of state shortages.

Although the Revolutionary Offensive intended to rid society of the lags of a bourgeois past, it had unintended consequences and it fueled the politics of disaffection. Interviews from the Oscar Lewis Collection reveal that by 1969 Cubans often engaged in a black market; illegal trades between neighbors of consumer goods such as condensed milk, cigarettes, and beer, became a practice of the politics of affect. ${ }^{104}$ Absenteeism began to rise as well; it complicated the achievement of production goals during and in the aftermath of the harvest. Two years into its second decade the Revolution faced mass

\footnotetext{
${ }^{104}$ See Chapter 4.
} 
disillusionment in the ideals of the late sixties, the "fraying" of fidelismo, and the proliferation of the politics of affection in everyday life. ${ }^{105}$

In this chapter I argue that officials used celebrations to ensure the endurance of the Revolution's emotive regime beyond 1970. State institutions and officials, like the National Council of Culture and the guides at international festivals, acted as the emotional managers of the regime by organizing events intended to evoke and portray joy. The return to large-scale celebrations at this juncture suggests that officials were aware of the emotional undercurrents that marked the harvest's failure. As the chapter will show, recreating joy was more than an attempt to give respite to Cubans who gave up carnival traditions in the name of the Revolutionary Offensive. It was also an opportunity to reverse course and eradicate the negative associations with revolutionary failure from the minds of Cubans and international audiences.

The chapter traces the organization and return of two popular celebrations in the seventies: Varadero's Music Festival and Carnival. Official documents, speeches, and newspapers show that behind the floats and carnival troupes, official managers deployed valuable resources to ensure that the Cuba Revolution retained its joyous character.

\footnotetext{
${ }^{105}$ Fidelismo and the politics of affection are separate; in this case fidelismo is an extension of the politics of passion. The politics of affection operate in the spaces outside of official purview, while fidelismo characterized official culture.
} 


\section{A FESTIVAL UNDER THE CUBAN SUN}

During the first two weeks of December 1967 Cuba hosted its first International Festival of Popular Music in Varadero (historically a resort town). ${ }^{106}$ The shift of the festival from national to international was preceded by the International Meeting of the Canción Protesta (protest song) in July of the same year. Estela Bravo, Haydeé Santa María, and Harold Gramatges invited songwriters to the social-cultural organization, Casa de las Américas. The reports from the meeting concluded that "song is a weapon at the service of the people, not a capitalist consumer product ... [T] he task of the workers of the protest song must be developed from a defined position taking beside their people, [and] facing the problem of the Society in which he lives." Protests songs required that artists commit to a political engagement to exalt social ideals. ${ }^{107}$ Songwriter and singer, Pablo Milanés, recalls how two months after the international meeting, Casa de las Américas' Center for Popular Music invited "young voices" of the genre to share their music. ${ }^{108}$ The popularity of the canción protesta in the sixties in Latin American countries inspired the theme of the first international gathering in Varadero.

In 1967, the festival welcomed artists from Latin American and European countries. The musicians represented eighteen countries (not including Cuba); the countries that made up the list included Mexico, Uruguay, Spain, and England. The

\footnotetext{
${ }^{106}$ In 1965, the first Popular Music Festival was celebrated at the national level, consisting of Cuban artists and titled "Festival de la canción; the festival was transformed into an international event in 1967. See Pedraza Ginori, "Vamonos al festival de Varadero,." El Blog de Pedraza Ginori (blog), November 27, 2015, http://elblogdepedrazaginori.blogspot.com/2015/11/vamonos-al-festival-de-varadero.html.

${ }^{107}$ See Robin Moore, “Transformations in Cuban Nueva Trova, 1965-95," Ethnomusicology 47, no. 1 (2003): 1-41; Jan Farley, Living Politics, Making Music (New York: Routledge, 2016).

${ }^{108}$ Pablo Milanés, Con luz propia (Navarra: Rave, 1994), 35-40.
} 
Eastern European bloc had the strongest presence at the festival, with seven countries sending musicians. Out of the thirty-six visiting acts set to perform throughout the festival, fifteen hailed from Soviet-aligned bloc countries. Cuba was also represented at the festival by nine artists, which included Bola de Nieve and Omara Portuondo. In total, the festival welcomed 101 musicians to perform on various stages for two weeks.

The Cuban state made funds available to the National Council of Culture that included payment for the artists and supporting event logistics. Internal invoices and receipts in the MINCULT archives show that a significant amount of money was transferred directly to the council for this purpose. A 1968 expense report from the council shows a breakdown of the festival budget that included lines for artists' salaries and a fixed diet, or daily meals, for technicians. The report also contained justifications for each line item, including \$5 spent on medicine for one of the international performers; details on the exact amounts spent on food outside of the fixed diet were not spelled out on the report, and invoices for air travel were redacted from the final budget. One of these invoices, for twelve airline tickets for the Bulgarian musicians, totaled $\$ 9,871.20{ }^{109}$ The numbers in Table 1 only account for a portion of the money spent on the 1967 festival. Monetary investment in this event indicates the importance of the occasion and the expectations that this meeting would lead to a new future for Cuban music and artists.

\footnotetext{
109 “Festival de Varadero," Box 357, MINCULT Archives.
} 
Table 1: Sample Expenses for Artists of the Varadero Music Festival in $1967{ }^{110}$

\begin{tabular}{|c|c|}
\hline Salaries (for performances)* & $38,000.00$ \\
\hline Consumption Receipts (Food and Travel) & $4,614.82$ \\
\hline Food (Technicians) & $23,523.00$ \\
\hline Medicines & 5.00 \\
\hline Receipts & 114.47 \\
\hline Services & $19,584.17$ \\
\hline & $85,841.46$ \\
\hline
\end{tabular}

Source: MINCULT Archives.

Artists not only performed on the main stage, but they also held performances in three Varadero cabarets and two night-clubs; these events were open to the public. The promotional plan had specific instructions to dedicate spaces on Cuban television programs to the festival. The publicity plan devised by the National Council of Culture included inserting the topic into sketches, giving away trips to Varadero during the dates of the festival, news reports from the event site, and pre-circulated quotes and interviews for the state press to include in their accounts. International artists praised the 1967 festival's non-competitive character, free admission, and conditions of the stage. The last show took place at Varadero's amphitheater, which reports boasted, could hold 10,000 audience members. According to these reports, the total number of attendees to all public performances during the festival totaled $112,117 .^{111}$

\footnotetext{
${ }^{110}$ Figures are reported in Cuban pesos. Official rules for the festival guaranteed artists a minimum of five performances and $\$ 100$ per performance. The CNC "guaranteed to pay hotel, food, and internal transport." Box 357, MINCULT Archives.

${ }^{111}$ Consejo Nacional de Cultura report, "Festival de la Canción Popular, Varadero 67," Festival de Varadero, Box 358, MINCULT Archives.
} 
Television and radio broadcast performances across Cuba, although it is not clear that all festival gatherings were shared via these mediums. After the festival, some concerts in Havana also commemorated the success of the event. The festival's official rules explicitly stated that artists were "free to accept any contract offered to them to act in theater, cabaret, radio or television." 112 The festival marked the winding down of 1967; music and international artists on stages in the nation's capital paved the way for a new year and the eventual declaration of the Revolutionary Offensive.

On January 2, 1968, Fidel Castro delivered a speech to commemorate the ninth anniversary of the Revolution that called for the rationing of oil. According to Castro, Cuba could not continue to look out for Soviet ships to solve their troubles. This was a response to the slowing shipments from the Soviet Union, as a result of conflicts between both governments over Cuba's foreign policy. ${ }^{113}$ Towards the end of his speech Fidel sent a message by declaring that Cuba would, "carry forward its internationalist policy without hesitation of any kind and in solidarity with the revolutionary movement throughout the world [...] our country will also maintain its signature ideology, its criterion, its most absolute independence, its own way, elaborated by our people and our experiences and according to our tasks." ${ }^{114}$ Within two days, and less than a month after

\footnotetext{
112 “Fotografías y Entrevistas,” Box 359, MINCULT Archives.

${ }^{113}$ For more on the economic ties between the Soviet Union and Cuba, see Carmelo Mesa- Lago, The Economy of Socialist Cuba: A Two Decade Appraisal (Albuquerque: University of New Mexico Press, 1981).

${ }^{114}$ Fidel Castro, "Discurso pronunciado al conmemorarse el IX Aniversario del Triunfo de la Revolución, en la Plaza de la Revolución, el 2 de enero de 1968," accessed January 20, 2019, http://www.cuba.cu/gobierno/discursos/1968/esp/f020168e.html.
} 
the first international music festival, Cuba gathered scholars from around the world, ranging from musicians to economists, for the Cultural Congress of Havana. ${ }^{115}$ The conferences focused on discussing the ideas of Revolution as a response to imperialism; the Congress sought to provide answers to Cuba's challenges. Although the name of the congress implied that at its core the discussion would be culture, it was a signal of an official detour from formal support of culture to state surveillance of artistic productions. Larger-than-life economic initiatives such as the Revolutionary Offensive dwarfed the Varadero festival and took center stage. When those initiatives fell short, the government sought a new course of action that placed a heavy emphasis on culture once again. Officials manufactured moments of joy to distract Cubans from dwelling in disillusionment. ${ }^{116}$

\footnotetext{
115 The Congress was important because it put forth an official perspective on the role of culture not only within Cuban society but also for revolutions in the third world. It gathered scholars from over 70 countries to discuss what it meant to be part of a revolution as an intellectual, the defense of Cuba and Vietnam, and the example of Che Guevara. It also addressed the subject of poverty not only as an economic problem but a cultural one as well. Participants questioned in which ways they could contribute to social changes within their communities. The answer was to perform works that accounted for the daily realities of the people, that is to abandon individualistic tendencies and think about the collective experience. This collective experience referred to that of Third World revolutions. The success of revolutionary movements, such as Cuba's, depended upon self-definition in resistance to imperialism. Thus, the fight for political control also contained cultural disputes which in the end required the subversion of intellectuals and society in order to succeed. For more on the Cultural Congress of Havana see Rebecca Gordon-Nesbitt, To Defend the Revolution Is to Defend Culture (Oakland: PM Press, 2015).

${ }^{116}$ Indicative of the success of the carnival was the immediate announcement of dates for the next year: 1524 of November.
} 


\section{PACHANGA FOR ALL: PROMISES OF CELEBRATION AND THE RETURN OF CARNIVAL}

When the Revolutionary Offensive turned into the state imperative Cubans were asked to sacrifice more than their time, and popular celebrations were postponed. According to Castro, people wasted time in the preparation and celebration of a carnival. Instead, the party could wait for after the harvest. In a 1969 speech, Castro declared that the pig, beans, and nougat would reappear in July, a symbolic month for the Revolutionary movement. The culmination of the harvest would be more than one celebration; the traditional staples of a Cuban Christmas menu could reappear in July, just in time to celebrate the 26th of July Movement's anniversary. Castro not only promised food to his audience but also "the Bacardí, the cognac, the beer and all the things that are necessary [for a celebration]. Then, we will have a party in Santiago and all the towns. And then, we will have carnivals, and we will have everything in July." ${ }^{117}$ The promise of future celebrations, including the return of coveted food and alcohol in the name of a carnival, marked the height of the Ten-Million-Ton Harvest. Cuba, at the time of this speech, had produced 126, 000 tons of sugar and had less than eight months to reach the ten million mark. The failure of the harvest signaled the end of 1960s idealism and the beginning of an era of re-assessment and re-structuring for the Cuban government. It also meant that officials needed to account for the emotive impacts of the harvest's failure on the stability of the Revolution's emotive regime.

\footnotetext{
${ }^{117}$ Fidel Castro, "Discurso pronunciado en el acto para dar inicio a la etapa masiva de la zafra de los 10 Millones de Toneladas, efectuado en el Teatro 'Chaplin', La Habana, el 27 de octubre de 1969," accessed October 12, 2019, http://www.cuba.cu/gobierno/discursos/1969/esp/f271069e.html.
} 
In 1970, the magazine Bohemia opened three consecutive issues with tantalizing descriptions of what was in store for July 26. In the first issue, the magazine declared that the Cuban people, "jubilant like never before," had worked to close the 1970 harvest with the highest effort. The article went on to explain how the date celebrated all the things that the Revolution "sowed" from the sacrifices of July 26, 1955; these included schools, hospitals, the liberated land, and the ability to become a dignified man. The Cuban people had "the full right to dress up and let its laughter run freely. Joy was [theirs]." Articles about carnival kindled a sense of anticipation previously lost to the masses while in the throes of the Revolutionary Offensive. The collective anticipation and disillusionment from the harvest made carnival a welcomed break from the daily routine. The carnival was a space for emotive performances and catharsis, from the official podium to the streets.

On July 26th, 1970, during a speech commemorating the anniversary of the assault on the Moncada Barracks, Fidel Castro dissected the failure of the harvest. He expressed how it was a collective (he used the pronoun 'we') "illusion" of achieving "utopia." In the speech, Castro recognized that the requirements to mobilize the masses towards the collection of Ten-Million-Tons of sugar had its faults and consequences. These faults included a lack of foresight in production sectors, a shortened workday, and moral incentives that could not do away with everyday problems. In the speech, Cuba's debts were blamed on the ironies and illusions Cubans created for themselves. Thus, Cubans were responsible for these debts and the failure to meet the needs of the Revolution. The needs of the Revolution referred to the transformation of Cubans into the image of the New Man. Castro noted that a re-assessment of administrative practices was 
necessary to achieve the Revolution's vision for Cuban society. Cubans had to try to achieve "universal consciousness" or awakening. The speech is an example of the revolutionary tradition of self-criticism practiced in schools and workplaces in the late sixties; it also coincided with the return of carnival to the street of Havana. One can imagine how carnival celebrations helped to dull the sting of Castro's assessment of the zafra as a collective failure. Although Castro's voice and mannerisms made the speech an emotive performance, it was anticipation built during the years of the offensive that drew the masses to the streets.

The return of carnival not only fulfilled promises of celebrations after the harvest, but it also created a space for emotional catharsis. The party extended across "kilometers of happiness;" organs of the state were responsible for building and operating food and beverage kiosks. ${ }^{118}$ Blogs from Cubans who experienced the revived carnival recall the occasion as a great party in which people flooded the streets of Vedado in Havana to celebrate the return of a historic cultural tradition. These accounts are laden with language that stresses the emotive character of the occasion. Carlos Rodríguez Búa, a young man at the time, describes the atmosphere leading up to the celebration as "downcast;" the country was "depressed by the obvious reality that, despite efforts and sacrifices, it was not always successful." The party extended to every corner of the island, with the government organizing and funding every aspect. Carlos's use of the expression "throwing the house out the window"119 in his recollection emphasizes how memorable

${ }^{118}$ Bohemia, July 3, 1970.

119 "Tirar la casa por la ventana" is an expression referring to a large celebration. 
the celebration was. Carnival had everything Fidel Castro promised in 1969. On sale were "food and drink that had long been lost;" together with the dancers, floats, and music, officials "created the right environment." ${ }^{20}$ Dancing, singing, and drinking were the orders of the day, and when people "threw pergas full of beer [...] the watchers turned a blind eye because the orders were for the people to have fun." ${ }^{121}$ Not all was beer and celebration, and officials had to break fights amongst carnival-goers:

"[L]ate at night the razors, the sticks, and hits from the police rained down [on the crowd]. At that time, a war brewed between tough guys and hipsters [...] And the police against everyone. The quarrels between tough guys and hipsters exploded for any reason or without one [...] The sides were well defined [by] the tough guys $[\ldots]$ with speckles, gold and platinum caps on their teeth, wide trousers, and Apache shoes. The hipsters [...] with manes and bell-bottom trousers. Some danced casino with Revé, and Los Van Van. The others contorted with rock; at that time, the ban [on rock music] had somewhat been lifted." 122123

\footnotetext{
${ }^{120}$ Carlos Rodríguez Búa ,"Carnavales de la Habana," Memorias de un Cubano (blog), March 27, 2014, http://memoriascubano.blogspot.com/2014/03/carnavales-de-la-habana.html.

${ }^{121}$ Pergas are large paper cups usually made of thick, waxed paper.

122 Carlos Rodríguez Búa ,"Carnavales de la Habana," Memorias de un Cubano (blog), March 27, 2014, http://memoriascubano.blogspot.com/2014/03/carnavales-de-la-habana.html.
}

${ }^{123}$ During the 1960s the government banned rock music, the Rolling Stones and the Beatles were the clandestine sound of youth parties, jeans and long hair were the symbols of cultural deviancy and antithetical to the Revolutionary morale. Los Revé and Los Van Van blended Cuban and 1960s rock sounds, creating their brand of popular music. Out of the two, Los Van Van would gain popularity throughout the 1970s. The name of the group was inspired by the famous phrase of the harvest, "los diez millones van." "Los diez millones van" was a popular phrase, or call to action, meaning that Cubans would reach the Ten-Million-Ton goal. 
Stories of public disruptions and violence during carnival season pre-date the Revolutionary period but Rodríguez Búa's description of the participants in the Havana carnival's brawls are symbolic of a shift in official attitudes at the beginning of the decade. ${ }^{124}$ Although rock music and long hair continued to be looked down upon, by the 1970s they were tolerated. ${ }^{125}$

While Los Van Van were popular, it was not their music that set the beat to the carnival celebration. One song became an anthem for the carnival crowds: "Perico no llores más" ("Parakeet don’t cry anymore"). In the song, the parakeet has made a mess and will not stop crying. The lyrics claim that he has placed himself in a jam, the singer does not know why the parakeet cries since everyone knows that he is at fault. The song had no political inclination, yet personal accounts reveal that the masses converted the lyrics to an allegory for the failure of the Revolutionary Offensive. Though in his speech Castro blamed the failure of the harvest on Cuban illusions, the widespread appropriation of the lyrics subverted the official rhetoric and ridiculed Castro. The song was played over and over. A popular interpretation portrayed the parakeet as Castro, and the mess was his attempt to mobilize Cubans in the march toward the Ten-Million-Tons of sugar. Today, Cubans continue to refer to the song as "the parakeet is crying" instead of its official name, a testament to its popular interpretation during the 1970 carnival season.

\footnotetext{
124 For more about carnival see Thomas F. Anderson, Carnival and National Identity in the Poetry of Afrocubanismo (Gainesville: University Press of Florida, 2011).

125 About rock music, the Beatles and socialist youth culture, see Anne Luke, "Listening to los Beatles: Being Young in 1960s Cuba," in The Socialist Sixties: Crossing Borders in the Second World (Bloomington: Indiana University Press, 2013), 287-303.
} 
Tápale la boca a ese perico que está gritando

Con la maraña que ha hecho está llorando

Cover that parakeet's mouth he is screaming

With the mess he's made he is crying

El se cree que con nosotros nena se está jugando

Pregúntale a Rafael, la culpa la tiene El

He thinks that with us baby is playing

Ask Rafael, the fault lies with him

Ay pero yo no sé por qué

él mismo se está embarcando

Oh but I do not know why

he is putting himself in a jam

Yo no sé porqué

el perico está llorando

I do not know why

the parakeet is crying

Neither the fights nor the songs made an appearance in press coverage of the carnival; still, these musical expressions and interpretations had an impact on the organization of future celebrations. The music of the carnival was a stark contrast to the 
protest song of 1967. Slow melodies and the idealistic rhetoric made protest songs appealing to younger audiences, although international music had a broader appeal. Shortly after the Havana Carnival celebrations ceased, the state adopted popular music to manage the international perceptions of the emotive regime through the 1970 Varadero Music Festival.

\section{THE REVOLUTION WELCOMES THE WORLD}

The Varadero Music Festival had its origins within the Revolution and presented some continuities in its form. Archival records also reveal the extent to which officials surveilled the emotions of foreign participants during the 1970 festival. At a time when the Cuban economy depended heavily on a limited number of countries for trade (mainly imports or economic aid), culture became a site for new diplomatic and economic possibilities; it was an investment in Cuba's future. Not only did the festival target the emotive community of Cuban youth, but it was also a tool to restore Cuba's festive image on the international imaginary. The plans for the Varadero Music Festival by the Council of National Culture (CNC) reveal that official management of the Revolution's emotive regime included efforts to project the Revolution and Cubans as joyful despite the recent failure of the ten-million-ton sugar campaign.

Just as Havana's Carnival made its return, the National Council of Culture prepared another comeback: the second International Festival of Popular Music or Varadero '70. Documents indicate that festival plans were in their initial stages the summer of that year, just as the carnival was making its raucous return to the streets. The Center for Musical Development, Programming, and Broadcasting received a request to 
submit names of international artists for consideration. ${ }^{126}$ The event's prospective guest list quickly evolved in caliber to include high-profile names, from foreign cultural ambassadors to record label representatives and European music festival directors. Before an invitation went out, individuals were organized according to the country of origin and assessed according to their popularity, political views, and affiliations. The list of potential French performers demonstrates the extent to which festival organizers controlled every detail to project the desired image at home and abroad. Thus, it is not surprising that long hair was a valid reason to be taken off the guest list. In the case of Sylvie Vartan, there was a potential that she could be "a bad example for the girls." Vartan was also married to Johnny Halladay, who was on the prospective guest list but was "not advised for Cuban youth;" part of the reason was a statement, in quotes: "considered, by us, an idol." "127 Officials were cautious of the feelings or ideas that seeing these performers on Cuban stages could inspire amongst the youth on the Island.

Both artists were symbolic of the rock and roll generation, which state officials publicly mocked and prosecuted in the late 1960s. ${ }^{128}$ Artists who made it onto the first official guest list held a "physical appearance and moral behavior [...] in accordance to the principles of the Revolution" and were sympathetic to or had an understanding of

\footnotetext{
126 The Center for Musical Development, Programming, and Broadcasting was established in 1968 to promote universal and Cuban music. For more details, see Paulo Cannabrava Cilho, En el ojo de la tormenta (Plaza y Valdés, 2000).

127 "Lista de artistas franceses," Festival de Varadero, Box 359, MINCULT Archives.

${ }^{128}$ As early as 1963, Castro paints a negative picture of the rock and roll youth and correlates it to a classist past. Fidel declared: "Muchos de esos pepillos vagos, hijos de burgueses, andan por ahí con unos pantaloncitos demasiado estrechos (risas); algunos de ellos con una guitarrita en actitudes "elvispreslianas." / "Many of those lazy youths, children of the bourgeoisie, go around with panths that are too narrow (laughs); some of them with a little guitar in 'Elvis Presley' attitudes."
} 
Cuba's socialist Revolution. ${ }^{129}$ The requirements for artists greatly reduced the guest list but did not deter organizers from inviting prominent, international officials and diplomatic attachés. Festival organizers did not scrutinize these foreign attachés according to the instructions developed for artists; they would not appear on stage or in front of the Cuban youth. International representatives invited to Varadero 70 not only held positions within cultural departments but also became potential partners for the development and circulation of Cuban culture abroad.

To-do lists developed in preparation for the festival addressed the aesthetic presence of Varadero's Hotel Internacional and the surrounding areas to ensure that festival guests were presented with the best Cuba had to offer; no expense was spared. Details that required attention included painting the pool and bar area, and the circulation of the national press. ${ }^{130}$ The official budget recorded for Varadero 70 appears to have doubled that of the money spent on the 1967 festival. One notable increase was the money allocated toward air travel $(\$ 147,225.07)$, but this is not surprising considering the increase in attendance. The 1970 festival counted with over 100 international artists, who also brought along their bands and, in some cases, spouses, cultural attachés, actors, and foreign press. According to festival records, over 200 guests stayed in Varadero hotels paid for by the National Council of Culture. A large portion of the festival budget was allocated toward food and hotel stay: $\$ 99,344.93$. Although the amount spent on hotel and food services for festival guests was not recorded in the final budget, copies of

\footnotetext{
129 "Festival de la Cancion Varadero 70: Instrucciones para cursar invitaciones," Notes on Jecek Dobierski, Festival de Varadero, Box 358, MINCULT Archives.

${ }^{130}$ Notes on Jecek Dobierski, Festival de Varadero, Box 359, MINCULT Archives.
} 
invoices for the 1970 festival indicate that this line item did not increase when compared to the 1967 expenses. Organization and details mark the difference between the budgets. The lists developed by organizers in 1970 not only accounted for preparation and set up of venues, but there were also itemized lists of zippers, buttons, fabric, and souvenirs; a food list accounted for every pound of butter, lobster, and meat necessary to feed guests. Officials were working towards making the fantasy and allure of the Caribbean island a reality by carefully planning each detail of the festival experience.

In 1967, the Romanian singer Margarita Bislaru summarized how Cuba appeared to many in the late sixties and early seventies:

This festival has a great significance for me [...] [Cuba] is a country of dreams, of stories, of the stories that my grandmother used to tell me when I was a child when she told me about an exceptionally beautiful country, imaginary. From the airplane [...] to me Cuba, seemed a beautiful painting, a beautiful painting. ${ }^{131}$

The image of Cuba in the international imaginary as a beautiful painting did not dissipate over the years. Many of the international guests were drawn to the festival because it presented an opportunity to see for themselves if the stories were true. ${ }^{132}$ This was an opening not afforded to many since Cuba's tourism industry would not become a state

\footnotetext{
${ }^{131}$ Festival de Varadero, Box 353, MINCULT Archives.

${ }^{132}$ In the case of the Soviet bloc, scholars have begun to explore the romantic ideal which Cuba represented in the socialist imaginary. In the 1960s, "the Cuban Revolution evoked the youthful excitement of the Russian Revolution. For some younger people, it offered a heady opportunity to finally participate, if at a distance, in a revolution of their own." See Anne E. Gorsuch, ““'Cuba, My Love”: The Romance of Revolutionary Cuba in the Soviet Sixties," The American Historical Review 120 , no. 2 (2015), 497-526.
} 
imperative until the 1980s. ${ }^{133}$ In the 1960s and 70s, foreigners did not have access to the island unless it was through a state-sponsored program. This fact and the physical distance from the Eastern European bloc made Cuba alluring as a remote destination where socialism thrived under the Caribbean sun. While artists had professional commitments with rehearsals and interviews throughout their visit, festival organizers invited artists to sites of historical and economic importance. Scheduled activities for guests included visits to nearby production centers in Matanzas, where guests were taken on guided tours of the facilities and met workers. When they were not taking part in factory tours, guests were treated to excursions at Guamá, the Bay of Pigs, and, in some cases, the Cuban capital. Festival guests enjoyed the miles of white, sandy beaches by their hotels.

The $\mathrm{CNC}$ assigned musical groups and distinguished guests Cuban guides to ensure that the international crowd at the festival had a good experience and saw how Cubans continued to progress in a joyous Revolution. These guides, provided by government agencies such as the Ministry of Foreign Affairs (MINREX for its Spanish initials), doubled as the eyes and ears of the state; each day, they wrote their observations. There were no paper forms for these reports; instead, they followed the same formula: an initial evaluation of the individual that noted his/her political and economic situation, accompanied by snippets of conversations and exchanges. Written reports on hotel letterhead and novelty, festival notepads were later transcribed via a typewriter at the

${ }^{133}$ See Philip Brenner, eds., A Contemporary Cuba Reader: Reinventing the Revolution (Lanham, MD: Rowman and Littlefield, 2008), and Rosalie Schwartz, Pleasure Island: Tourism and Temptation in Cuba (Lincoln: University of Nebraska Press, 1999). 
National Council of Culture. The stories in the reports give an insight into the day-to-day exchanges between guests; the voice of the translators read like side-line commentators to the behind-the-scenes activities in Varadero. The narrative of a complete report began with the initial meeting at the airport; translators described the attitude of the guest upon arrival, how they spoke of their first impressions of Cuba, and if these reflected a positive or negative undertone toward the Revolution. Once at the hotel, guides stayed by their assigned guest and observed their interactions with other festival guests, noting their comments about the quality of performers along with any feedback related to Cuba and its people. Reports were not only about political views; one guide included in his logs a note about his assigned guest arguing with their spouse.

While the observations documented an overall feeling of positivity toward the festival concept, one guest expressed his suspicions to his translator about the real purpose of these events. That guest was Jecek Dobierski, director of the Polish artistic agency PACART. While talking about the characteristics of the festival, Dobierski reminded his translator that he had forgotten one: the political character of the event. In this instance, he compared the festival to the Sopot International Song Festival. According to the notes, handwritten on hotel letterhead, Varadero 70, "like Sopot, always had a political underpinning well known to him." ${ }^{134}$ His insight into the political character of such events dated to his positions in Poland's Ministry of External Relations and Ministry of Culture. After spending some time with Dobierski, the translator not only noted his habit of skipping the cabaret bill at the end of the night but also that he had

\footnotetext{
${ }^{134}$ Notes on Jecek Dobierski, Festival de Varadero, Box 357, MINCULT Archives.
} 
dollars but did not exchange them. Instead, Jecek was given a stipend by festival organizers that he used during his time in Cuba.

Although he received a stipend and was considered a special guest, Dobierski's initial impressions did not change. On November 15, 1970, Jecek accompanied artists to a press conference. During the conversation, reporters spoke of Eva Pilarova, Czech singer, and her participation in the previous cane harvest. The anecdote was followed by a request from the Centenary Youth Columns' (CJC) representative for the Polish singer, Maryla Rodowicz, to send a message to the people in preparation for the next harvest. After the interview, the translator makes a note of Dobierski's words to Maylla: "the festival has turned too political." 135 Two days later, Dobierski traveled to the Polish embassy in Havana. After the visit, his translator commented that "one can see that the comrades from the Polish Embassy in Cuba have brought him up to date on the economic situation of our country, with great details." 136 This must have been a disappointing conclusion for the Cuban companion tasked with showing guests the successes of the Revolution.

Dobierski was not the only person to look beyond the white sands and palm trees of Varadero 70. Karel Gott had a high opinion of the Cuban public and their response to the music but criticized Italian singer Sergio Endrigo, for leaning on politics to impress the audience. The guide noted how "it made sense for him to sing to 'Che' but not in a

\footnotetext{
${ }^{135}$ Ibid.

${ }^{136}$ Ibid.
} 
festival for popular song." ${ }^{\prime 37}$ The notes go on to say that an explanation was provided but this, it seems, did not make it into the final report. Commentary from guests performing in the festival, like Gott, tended to take account of the character of the Cuban public as a receptive audience. In other cases, comments about the stage conditions tended to range from praise for the hard work of technicians to make do with limited equipment to the success of the festival despite lacking technical components. It is apparent that the artist's commentary was limited to these areas of the performance due to the interest of the guide in recording these specific comments, but one also has to take into account that not everyone shared their reflections as candidly as Dobierski. ${ }^{138}$

The control and surveillance of Varadero '70 had their successes and failures. Corrado Carradi, an Italian reporter, appears in two reports and received a positive evaluation from his guide. He was there to cover the festival and claimed to be one of the trustworthy reporters that would give the festival an unbiased coverage. The CNC obtained a copy of his article, published in the Italian magazine Sorrisi e Canzoni. The article, published in December of the same year, was titled "Hard Life, Everything is Missing, Except the Joy of Living.” In the article Carradi paints a picture of the scarcity and its effects on Cuba: "Fierce rationing, from clothing to food; electric power with a dropper; the prices of the restaurants rise to the stars, but people are happy to live because they understand that they are building a new society [...] At the restaurant a steak costs 5

\footnotetext{
${ }^{137}$ Notes on Karel Gott, Festival de Varadero, Box 359, MINCULT Archive.

138 These notes are filtered in three identifiable ways: 1) self-imposed filter, 2) the questions asked/the answers recorded, 3) the condensed final report which grouped notes on a group of eighteen, such as Gott's, to less than 20 pages.
} 
thousand liras, a bottle of whiskey 32 thousand liras. A meal costs 20 pesos-two thousand liras $[\ldots]$ The matches don't work, or the reaction is so delayed you end up burning your fingers while the razors with the slogan 'venceremos' don't shave, making the act a bloody pyrrhic battle." Here the author cites Fidel's self-criticism in the aftermath of the harvest and reflects the narrative of necessary sacrifice to achieve the Revolution. Although the state worked to create an image of stability and flourishing socialism, it could not undo the reality of scarcity and its effects on everyday life on the island. The tours and guides of the festival succeeded in portraying Cuba as a joyous nation. Just like in the festival, the article notes how in the face of scarcity, the tourist turns toward nature. Carradi described how foreigners gazed at the ocean and contemplated the unspoiled beauty of the palm trees. The message in the article seems to echo that of the Cuban government's larger narrative of a temporary scarcity, a necessary sacrifice that was but a bump on the path of socialism, and an unwavering sentiment of joy within the Revolution's progress. Despite the official's failure to convince festival guests like Jecek, they succeeded in projecting the Revolution as joyful.

\section{REVOLUTIONIZING CARNIVAL}

Letters sent out to music experts in 1972 reveal the level of control with which the National Council of Culture developed plans for future carnivals across the nation; the organization of Havana's carnival would set the example. These letters to experts went out a month in advance of the July celebrations. Each one was addressed to a comrade, informing them that they were chosen to become a member of the Havana Carnival's Music Commission due to their technical qualifications. The letter went on to describe the functions of the advisor and how it required the supervision of two components: the 
musical (musical trend, interpretive quality) and its revolutionary themes. ${ }^{139}$ These were not the only measures taken by the National Council of Culture officials to ensure that the carnival presented the correct image and message. The Council oversaw every detail, from participatory requirements to the rules for judging contests, down to the exact number of hours and minutes carnival processions lasted each day.

Guidelines developed in 1972 were (in part) a response to the popular interpretation of Tata Güines's 1970 song and a reflection of the ideas discussed in the 1971 National Congress of Education and Culture. This was the same congress in which Fidel Castro spoke to the "mafia of bourgeois intellectuals." ${ }^{140}$ If people were not going to forget the failures of the last decade with a large party, then the solution was more organization to embody the accomplishments of the Revolution. One document recounts the historical roots of the carnival and its transformation after the Revolution:

[with] the triumph of the Revolution, Carnival acquires another meaning, consumer products are no longer advertised, but floats serve as a symbolic element of the creative work of our people...the Revolution, watches, and worries about the carnival.

The text embodied the rhetoric of the state; it reveals a paternalistic attitude towards the development of carnival within the context of the Cuban Revolutionary government. The document outlined plans for the Carnival of Havana and all cultural offices. It stressed

\footnotetext{
${ }^{139}$ Letter, Tony Henríques, head of programming for the National Music Headquarters, to experts, June 10th, 1972, Festival de Varadero, Box 356, MINCULT Archives.

${ }^{140}$ Fidel Castro, "Discurso pronunciado en la clausura del Primer Congreso Nacional de Educación y Cultura, efectuado en el Teatro de la CTC, el 30 de abril de 1971," accessed September 10, 2018, http://www.cuba.cu/gobierno/discursos/1971/esp/f300471e.html.
} 
that "the National Council of Culture [...] is obliged to supervise, monitor, and guide all the manifestations that appear in the Carnival." Under more control carnival would become "a true exponent of the popular festivities" by not allowing "tawdry forms, deformed from good taste [...] forms of ideological penetration [...]for example foreign musical forms, politically confusing lyrics in the songs, choreography scenes or themes used in floats that are not following the orientations of our Revolution." The parameters within which carnival could operate were clearly defined along the lines of control and surveillance, although to the public carnival continued to stress joy. The efforts to control carnival celebrations indicates that official managers of the regime viewed carnival as a valuable vehicle for manufacturing emotion.

Havana Carnival schedules reflect the extent to which the carnival had become a celebration of ideology. ${ }^{141}$ In 1972 , the carnival program, specifically the parade of floats and dance troupes, lasted ten days from July 16 to July 25. Parades included the participation of thirty-two groups representing political associations, segments of production and service industries, as well as four segments representing the traditional aspects of carnival such as the muñecones (giant dolls), el alacrán (the scorpion), la jardinera (the flower girl), and the star of the carnival (which before the Revolution was called the queen of the carnival). During the first day of celebration, all the floats and troupes participated in the parade, totaling thirty-seven segments and lasting over six hours. The rest of the carnival days, parades were composed of twenty to twenty-two

\footnotetext{
${ }^{141}$ For more information on the $\mathrm{CNC}$ and its leadership, see Par Kumaraswami, "Cultural Policy and Cultural Politics in Revolutionary Cuba: Re-Reading the Palabras a los Intelectuales (Words to the Intellectuals)," Bulletin of Latin American Research 28, no. 4 (2009): 527-41.
} 
segments, in which three were traditional, and the rest were the groups mentioned earlier representing the state offices and political organizations. These parades lasted half the time, a little over three hours, and celebrating the laborers and their contribution toward the advancement of socialism. Only in the first and last days of the carnival did four segments of the carnival consist of the traditional elements. So, during the first day, 91 percent of the parade segments were tied to representations of Revolutionary Culture, with 9 percent of the parade displaying traditional elements dating back to the 1930s. During the ten days of carnival in 1972, 83 percent of the parade segments were made up of official components, and 13 percent traditional elements.

Traditional elements received a Revolutionary spin. In the case of the Star of the Carnival, it was not only her title which changed in the context of socialism. In the 1970s, the contest required participants to have "revolutionary integration." Integration in this instance meant that each woman aspiring to become the star of the carnival "must be a member of the Syndicate, or Mass, or Student Organization." ${ }^{142}$ Accordingly, judges received instructions to base their decisions solely on their beauty since all the compañeras possessed all the established requirements on competition day. The competition for the Star of the Carnival of Havana received national press coverage, including radio and television. Once crowned, the star of the carnival appeared on spreads in Bohemia along with the luceros (bright starts). These articles continually quoted the feelings of surprise and happiness amongst contestants after the competition. They also lauded the characteristics that made them stars: an active, young, individual

\footnotetext{
${ }^{142}$ Qualification guidelines for the Star of the Carnival, Box 353, MINCULT Archives.
} 
who, like anyone else, was engaged in activities related to the advancement of the Cuban Revolution. Whether it was her status as a university student or her active involvement in socialist organizations in their respective areas, many profiles included tales of voluntary participation in the fields cutting sugarcane.

Spreads in Bohemia were not only a platform for showcasing the young participant's revolutionary attributes, but they also emphasized how each detail represented Cuban socialism. In a 1971 article, the focus was on Cuban's innovation, dedication, and voluntarism in all aspects. Although the styles worn by the contestants were not unique in their design, they were Cuban made. A team of dressmakers from the store Fin de Siglo ${ }^{143}$ were joined by 180 volunteers that ranged from workers in several production sectors to homemakers identified as members of Committees for the Defense of the Revolution (CDRs). All the volunteers were women; they worked on the costumes for parade troupes and dancers in addition to the outfits for the televised competition. When asked to share designs for parade outfits, the volunteers told reporters that these were to stay a secret until the day of the carnival; the mystery added to the excitement of the day. Bohemia's article on the fashion of the contest is an early indicator of how material culture "accompanied and contributed to the consolidation of a state socialist bureaucracy." 144 Investing in the carnival and counting down to the event by showing preparations, including the fantasy of fashion in the hands of Cubans, portrayed an image

\footnotetext{
${ }^{143}$ Fin de Siglo was well known department store well known before the Revolution for their elegant fashions.

${ }^{144}$ María A. Cabrera Arús, "The Material Promise of Socialist Modernity: Fashion and Domestic Space in the 1970s," in The Revolution from Within, Lamber and Bustamante, ed., 189-217.
} 
of stability. If Cubans continued to volunteer their labor, the state would provide the materials to dress the future. The fashions of the carnival were also a concession toward a younger generation; they were accommodating to modern styles that were popular amongst younger Cubans but also ridiculed in the 1960s. One, in particular, the miniskirt, accentuated the contestant's legs as they lined up on stage. Photographs from the Havana Carnival competition in 1964 captured young women in long, white ball gowns, while the competitors in the 1970s displayed a more modern interpretation, keeping the white of the earlier dresses but shortening the skirts.

Although the state did not provide dresses for contestants in other provinces, they did fund the infrastructure of carnival across the island. In Matanzas, the rum and soda factories were given production goals for carnival. The provincial newspaper, Girón, promised drinks and food on the big day. The only obstacle standing in the way of meeting the production goals was the lack of glass bottles. Scarcity was an on-going issue, but there was a solution: volunteer efforts in recycling. The newspaper published daily reminders to matanceros to collect bottles for these factories. Led by the CDR's, neighborhoods collected enough glass bottles to ensure that beverages were available at carnival booths within local municipalities. Like in the articles about carnival fashion, volunteers played an essential role in making the festivity possible for the masses. After all, the issue was not presented as the nationalized factories' ability to produce the raw product, in this case, alcoholic beverage, but the scarcity that was a by-product of imperialism's chokehold on the Cuban economy. Thus, the press, reflecting official rhetoric, continually asked Cubans to find ways of resolving these issues by volunteering their time and efforts in activities that would benefit the community. These efforts were 
not limited to the collection of empty glass bottles, calls for street cleanups and festive decor were collective, neighborhood duties throughout the year.

In the context of socialism and economic scarcity, manufacturing moments of joy required the participation of all. Leading up to carnival, students, CDR members, and workers volunteered their time to the production of the carnival. At the same time, the competition for the Star of the Carnival generated excitement and entertainment for all. On the day of the competition, contestants walked the stage in their miniskirts, smiling confidently at the judges and audience. The contest became one of the most successful and anticipated events during the carnival. Havana's carnival competition stood out from those in the rest of the country due to its broadcast on national television. The production value of the competition in the capital generated a buzz around the chosen winners, for a moment becoming household names thanks to the coverage of state press (see image 2). In local stages, the contest did not have the same production level, and in various cases, contestants were chosen from the audience. One contestant, who ended up winning the main title, expressed how unprepared she was to compete when she had to borrow a dress before getting on stage. Youth organizations, syndicates, and municipalities within the provinces held contests as well; there was even a child's version: la estrellita del carnival. Figures show just how popular the contest became; in the 1970 Carnival of Havana, there were 120 contestants, which grew to 140 contestants the following year. In Matanzas alone, participation in the competition counted with 117 participants in 1973. 
And while roughly 15, 000 attended the contest in Havana, in Santiago de Cuba, an audience of 20, 000 filled a baseball stadium to watch each round of the competition. ${ }^{145}$

The Revolutionary format, with a new name and political integration requirements, did not take away from the contradictions that it presented in contrast to the rhetoric of the Revolution. Although the participants all had the attributes of revolutionary integration, they were judged on their looks. Once crowned the Star was required to dance, on stage, with a worker from one of the syndicates. This worker, according to the press, was chosen based on his work ethic but did not have to compete on any stage. More disquieting were the activities after the contest, unspoken in the press but whispered and discussed amongst the public. Havana winners traveled to Varadero beach resorts where they would mingle with officials, including generals and party leaders. A number of these women would become the girlfriends and, in some cases, wives of these men. Thus, while the contest was supposed to be in line with the Revolution's message of the liberation of women, by presenting their political participation and stories of voluntarism, behind the scenes, they were placed in un-even power situations. Surprisingly, this did not lead to the cancellation of the contest.

Instead, it was the inability to retain control over the disgruntled crowds that led officials to cancel the contest. In 1974, the candidate from the Syndicate of Civil Aviation, María Félix Castillo Lemus did not hold the favor of the public. Instead, Nancy, number 14 , was the favorite but was cut during the first round. When the judges announced Castillo Lemus as the winner, whistles and calls for the now infamous number

145 “Carnaval de Oriente: La Estrella de Santiago de Cuba," Bohemia (July 31, 1970): 74-5. 
14 drowned the host's voice. In the face of scandal, wherein people questioned the authenticity of the contest in choosing a star, the contest was canceled. ${ }^{146}$ The reaction of the crowds threatened official's efforts to manage the emotive regime. Their swift reaction indicates that despite four years of carnival celebrations and manufacturing joy, any sign of displeasure threatened the stability of the emotive regime.

\section{CONCLUSION}

Large scale celebrations erupted in the wake of the harvest's failure. At first glance it appears odd that officials would plan a celebration with copious amounts of beer as the country experienced a massive letdown and economic uncertainty. However, in the context of an a political regime that routinely relied on community emotional responses, officials manufactured joy in this instance, though festivals and merrymaking, to counteract an emotional backlash with the potential to undermine the power of the emotive regime. During both events, the National Council of Culture proved itself a successful emotional manager as its members worked to plan festivities that not only conveyed the desired emotion (joy), but also planted anticipation for future celebrations.

On December 7, 1970, Fidel Castro stood before an audience at the closing of Cuba's Basic Industry's national plenary. There, he spoke of the festive character of the people of Santiago de Cuba and the problems of being a sugar nation with European holidays. Cane cutting needed to happen during the cold months and taking a break to celebrate Christmas during December was problematic in reaching production goals.

\footnotetext{
${ }^{146}$ Leading up to its cancellation, the contest was questioned by Vilma Espin, who did not believe that the contest was representative of the values of the Revolution since it made women's bodies a spectacle, and did not highlight the new role of women within the Revolution beyond their physical beauty.
} 
Cuba was not beholden to European traditions and would trace its course, independent of these. Castro declared that all holidays would be celebrated in July, and almost everyone would have a month of vacation in July, parents and children included, "a month of rest...with its $24,26,28,30,6$, its everything. More parties even! If you want, double! Nobody is against the parties."147 Officials like Castro understood that celebrations were more than an event; they evoked anticipation that distracted people from monotony and disillusionment. Yet as managers of the regime, officials also needed to do more than plan popular celebrations. As the next chapters will show officials had a variety of tools at their disposal to manage the regime.

${ }^{147}$ Fidel Castro, "Discurso pronunciado por el Comandante en Jefe Fidel Castro Ruz en la clausura de la plenaria nacional de la industria básica, efectuado en el teatro de la CTC, el 7 de diciembre de 1970," accessed October 10, 2019, http://www.fidelcastro.cu/es/discursos/discurso-pronunciado-en-la-clausura-dela-plenaria-nacional-de-la-industria-basica. 


\section{CHAPTER III}

Managing the Emotive Regime:

Magazines and Everyday Life in Cuba

The January 1968 cover of the magazine Mujeres featured Cuban women's participation in agriculture. A young woman in a light blue button-down shirt and a scarf over her hair grasps branches heavy with citrus fruits. The word Mujeres at the top of the image gives the impression that she is looking beyond the fruit and toward the magazine title as she gazes up. The cover reiterated the emphasis on agriculture and economic development at the beginning of the 1970s in Cuba, and it alluded to the Havana Greenbelt campaign (el Cordón de La Habana). The campaign, like the Ten-Million-Ton Harvest, relied on volunteer labor to achieve an agricultural feat. Cuban men and women would plant crops on 10,000 hectares on the outskirts of Havana. Growing crops outside of the city would cut the cost of transporting these goods from other parts of the island. According to the first page of the magazine in April 1968, "although the assigned numbers of plants [...] may seem exaggerated to the pusillanimous [individual], the people of Havana will know how to comply ... with faith in the future." ${ }^{148}$ The efforts to move the masses to plant coffee and fruit trees appeared in print, film, and radio.

Media played an essential part in the promotion of the greenbelt campaign. A new radio station, Radio Cordón de la Habana (Havana Greenbelt Radio), and a daily bulletin, Noti-Cordón de la Habana (HavanaNews-Belt), accompanied the campaign's

\footnotetext{
148 “A la agricultura,” Mujeres, (April 1968):3
} 
launch on April 17, 1968. ${ }^{149}$ The Federation of Cuban Women (FMC, for its Spanish initials) encouraged their members to participate in the campaign through the mass organization's magazine, Mujeres. The magazine's articles and comic strips focused on women's experiences planting coffee.
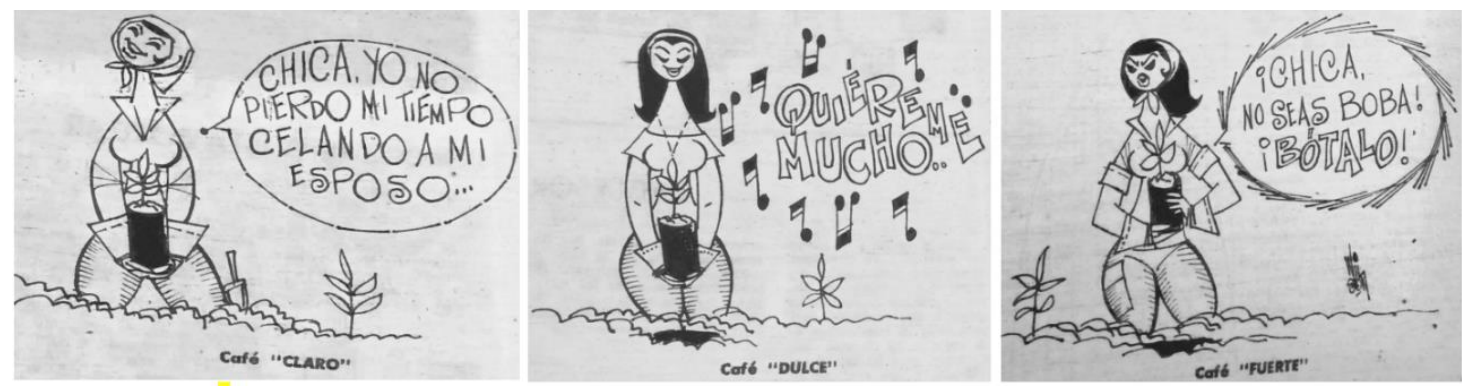

Figure 3.1. "Para tomarlo, hay que sembrarlo/To drink it, sow it." Mujeres (1968)

The caricatures of Cuban women, criollitas, displayed a positive disposition in the face of rain, mud, and heat. ${ }^{150}$ In the August 1968 issue of Mujeres, a description at the top of the comic strip explained to readers that "at the time of sowing [coffee], you should take care of your mood so that it does not affect your palate when it is time to savor [the coffee]." While "clear coffee" expressed that she did not have time to watch over her husband jealously, "sweet coffee" sang a love song; the woman planting "strong coffee" told her friend to "throw him out."151 The cartoon portrayed women's participation in the campaign; its humor targeted women's attitudes about work and love.

\footnotetext{
${ }^{149}$ Fidel Castro remarked that he read Noti-Cordón every morning, finding it interesting and suggesting an extension of the bulletin to Más allá del Cordón (Beyond the Belt). See Fidel Castro, "Discurso pronunciado en el acto conmemorativo del XI Aniversario de la Acción del 13 de marzo de 1957, efectuado en la escalinata de la Universidad de La Habana, el 13 de marzo de 1968," accessed January 9, 2017, http://www.cuba.cu/gobierno/discursos/1968/esp/f130368e.html.

${ }^{150}$ Criollitas refers to a series of cartoons about Cuban women by illustrator Luis Felipe Wilson Varela; these were a feature in the Cuban humor magazine Palante and were often published in the pages of Mujeres.

${ }^{151}$ Mujeres, (August 1968): 69.
} 
Although Mujeres was first and foremost a revolutionary publication, it was also a prescriptive text that showed Cuban women how they should engage in and feel about building socialism. The first issue of the magazine, published on November 15, 1961, materialized as a weapon against U.S. imperialism and as a tool to spread the ethos of the new government. The publication mirrored the rhetoric of the emotive regime in the early sixties and stoked anti-U.S. sentiments. ${ }^{152}$ But the magazine was more than antiimperialist rhetoric, it was also a space to discuss what it meant to be a revolutionary worker, mother, and wife in Cuba. The magazine's target audience were members of the FMC, the federadas. The editors also spoke to the Cuban housewives as readers with the potential to become active members of the organization. The magazine discussed a wide range of topics; it not only provided dress patterns, but also advised its readers on how to clean, behave in public, raise their children, and build a socialist family. Analyzing the content of the magazine as prescriptive adds meaning to the 1968 comic as more than a humorous take on planting coffee; it was also part of an emotional repertoire that modeled the emotions officials desired from women in their work and lives. ${ }^{153}$

In this chapter I argue that print culture, specifically magazines, helped officials manage the regime beyond the spaces for celebration. Magazines presented the emotive

\footnotetext{
152 Jana Lipman, Guantanamo: A Working-Class History between Empire and Revolution (Los Angeles: University of California Press, 2008), 172.

${ }^{153}$ In the sixties the Cuban government nationalized all the newspapers and magazines and founded the Cuban Institute for Cinematographic Arts and Industry (ICAIC for its Spanish initials) and the Cuban Institute for Radio (ICR for its Spanish initials). During these early years, newspapers acted as a medium for displaying the transparency of the new leadership; this included broadcasting and printing speeches and declarations. This extended to the magazines as well when they printed the speeches from the party. Although officials did not describe magazines as advice literature, the magazines' prescriptive role is evident in the development of the Revolution's print culture.
} 
repertoires of the regime to a broad audience and reached into the spaces of the everyday.

Article narratives and images inside the publications defined what it meant to be a

woman, neighbor, and worker inside the Revolution. Unlike speeches and newspaper

accounts, magazines provided a broader visual landscape to disseminate information

intended to transform Cubans' daily habits. The chapter highlights the role that

magazines played as instruments to communicate official emotional ideologies, and this

serve as primary sources for the study of emotions and everyday life inside the

Revolution.

Revolutionary magazines addressed the audiences officials considered essential to

building a modern Cuban society. Examples include Caiman Barbudo for the youth,

Mujeres for women, Con la Guardia en Alto for the Committees for the Defense of the

Revolution (CDRs), Verde Olivo for the military, and Coctel for service industry

workers. These magazines promoted mass participation in social, educational, and

economic campaigns. ${ }^{154}$ This chapter describes official discourses and representations of

\footnotetext{
${ }^{154}$ Like film, magazines endorsed the grand narrative of the state through images and discourses of revolutionary progress. Film presented an appealing medium to showcase the work in the fields as it integrated image and sound. ICAIC tasked filmmaker Nicolás Guillén Landrián with creating a short about the Greenbelt. The resulting film, Coffea Arábiga (1968), signaled Guillén Landrián's undoing. The film was "a labor of love" for Guillén Landrián that also contained his "propensity to doubt." During the first minutes, a voice drones a describing a step-by-step process of planting and defines technical terminology. The documentary short describes the steps to plant coffee, including definitions of technical terms such as pergolas. The film cuts to a woman walking around Havana; she is stopped and asked if she knows about the agricultural campaign. The woman describes the process of growing coffee in Bulgarian. Guillén Landrián intended to highlight the incorporation of women in labor outside of the home. Although it was intended as a praise of the Revolution's accomplishments, the failure of the greenbelt turned this scene "into an international critique of the Revolution's exploitation." Lillian Guerra presents the films by Nicolás Guillén Landrián as an example of the tensions between the hyper-real narratives of revolutionary progress and the real censorship of criticism of the Cuban Revolution and its leadership. According to Guerra ICAIC and the censorship of its artists reveals "imagery's importance to struggles over the grand narrative" of the Revolution. The evolution of production practices and censorship within ICAIC reveal how repressive cultural measures impacted artistic productions and representations of affect. Michael Bustamante describes how director "Humberto Solás's Un día de noviembre (One Day in November) featured characters struggling to reckon with their histories amid their safely socialist yet somehow
} 
revolutionary everyday life during the second decade of the Cuban Revolution through three magazines: Mujeres, Con la guardia en alto, and Coctel. The first two magazines, edited and distributed by the FMC and CDR respectively, addressed how to lead a Revolutionary life inside homes and neighborhoods. The magazines recorded the waning of mass enthusiasm that marked the Revolution's early years and the official response to recover popular support. They also capture how mass organizations transformed mass participation into a requisite of everyday life for Cubans. The third publication, Coctel, was the magazine for workers of the National Institute for the Tourism Industry (INIT, for its Spanish initials). All three, while attending to diverse groups, shared an audience in one sector of the population: women. Throughout the chapter, I show how officials intervened in women's everyday experiences and how housewives became a figure of the emotive regime and the face of a state campaign that promised to please all Cubans.

\section{IMAGINING THE FUTURE}

The FMC followed the Revolution's ethos regarding gender, and it focused on making political participation not only a right but a duty. The challenge for the editors of Mujeres, as the sole magazine for women, was its role in advancing the political integration of women while also attending to other interests such as fashion and homemaking. During the early sixties, the magazine politicized fashion and beauty to emphasize the transformative power of economic and political integration for women. In December 1961, Castro declared himself a Marxist-Leninist "until the end of my life,"

ambivalent lives.” See Lillian Guerra, "The Reel, Real, and Hyper-Real Revolution.” in Scripting Revolution: A Historical Approach to the Comparative Study of Revolutions, Dan Edelstein and Keith Michael Baker, eds., (Stanford: Stanford University Press, 2015), 267-286; on film and dissatisfaction, see Michael Bustamante, “Anniversary Overload?” in The Revolution from Within, 232. 
the revolutionary movement as scientific socialism, and Cuban politics as communist. ${ }^{155}$ A piece on Hungarian fashion in Mujeres coincided with the declaration. It noted that "one of the things that attract the most attention in the Hungarian capital of Budapest is the elegance of its women, of all ages and all types." The secret behind the fashionable reputation of Budapest's women were neighborhood fashion houses that "satisfy [the] major interest of looking good at all times." These fashion houses depended on women working from home; they would receive the cut of fabric and sew the dress. According to the report, not only did these homes keep women fashionable, they also provided them with jobs that had "all kinds of social protection" and paid 1000 to 1,200 florins. If the women used the sewing machines they owned at home, they would earn an additional amount. The magazine presented the Hungarian women's job opportunity at home as the ideal situation: these women were integrated into production "without abandoning their homes."156 The use of the word "abandonment" mirrored prevalent traditional attitudes within Cuban households that made it difficult for women to transition into the workplace. $^{157}$

In the fashion article, the Hungarian example not only coincided with Castro's announcement, but it also helped to promote the idea that women could take a skill they used at home and apply it toward helping society stay fashionable. That same year

\footnotetext{
${ }^{155}$ Fidel Castro, Fidel Castro speaks on Marxism-Leninism. Dec. 2, 1961, (New York: Fair Play for Cuba Committee, 1961).

${ }^{156}$ O.A., "Elegancia en la moda húngara," Mujeres (December 1961): 72-74.

${ }^{157}$ See Lois M. Smith and Alfred Padula, Sex and Revolution: Women in Socialist Cuba (New York: Oxford University Press, 1996).
} 
(1961), the revolutionary government founded Las Escuelas de Ana Betancourt. The Ana Betancourt Schools taught over 100,000 Cuban women from rural areas how to sew. The vocational school also taught them about revolutionary ideology and stressed the importance of formal education to its students. The article about fashion houses had an audience within the readership of Mujeres and aligned with the state's effort to show women the possibilities of economic integration. ${ }^{158}$ Georgina Duvallon, a founding journalist of the magazine, described the need for the magazine as "want[ing] to completely change the conception of this magazine, from one that simply gathered inconsequential material into one that captured Cuban women at their peak, with grand perspectives on the realization of their part in the process of Revolution that, by then, was in full swing." 159 The magazine embraced the idea of equality between men and women in politics and the workplace. It espoused the departure of women from the household. Thus, Mujeres mirrored the call of the FMC to defend the Revolution; it sought to draw the attention of the reader away from conventional, gendered roles at home.

Mujeres blended political rhetoric and traditional standards of femininity for its readers. In a 1962 article, "Socialism Is a Source of Beauty," the editors not only equate civic education with beauty but also happiness:

\footnotetext{
${ }^{158}$ See Denise F. Blum, Cuban Youth and Revolutionary Values: Educating the New Socialist Citizen (Austin: University of Texas Press, 2011), Chapter 2.

${ }^{159}$ María del Carmen Mestas, Gladys Eques, and Mercedes Verdeses, “Cubanas en Revolución,” Mujeres (November 16, 2001).
} 
There cannot be a beautiful woman without culture and economic independence, $[\ldots]$ the Cuban woman whom the Revolution has given all rights, can live happily thinking about the smiling future that awaits her children...[She] has a chance to enjoy as never before these truly beautiful things that brighten their existence. Everything that we do in favor of beauty inside or outside the home, in our workplace, or for the benefit of our people, will help us all feel happier, [and will help] the Cuba reborn with the January Revolution be more prosperous. ${ }^{160}$

The magazine's association of feminine beauty and socialism mirrored FMC leaders' view that the organization was "feminine, not feminist." 161 Thus, because the Revolution granted women equality, feminist issues such as sexual violence and lesbianism were never included in the discussions of the FMC or its magazine. ${ }^{162}$ Instead, Mujeres's early publications focused on women in production sectors, education, child care, and projections of Cuba's socialist future. During the sixties a large portion of magazine issues contained a section on the first page titled "Women in Production." The magazine used this section to feature production sectors and the federadas who worked in them. The FMC encouraged women to take advantage of the new opportunities the new Cuban government provided and volunteer their time in social welfare campaigns. Throughout

\footnotetext{
160 "El socialismo es fuente de belleza," Mujeres (March 1962).

161 Vilma Espín clarified that the FMC was not feminist in a 1974 interview with a foreign correspondent. See Lois M. Smith and Alfred Padula, Sex and Revolution: Women in Socialist Cuba, 182.

162 On lesbianism and feminist groups in Cuba see Myriam J.A. Chancy, From Sugar to Revolution: Women's Visions of Haiti (Ontario: Wilfrid Laurier University Press, 2012).
} 
the decade, the government set out to achieve free, universal education and healthcare, housing, and full employment for all. While the members of the FMC worked to organize the provincial groups of the organization, they also labored to complete the tasks set by the Cuban government. Young women made up more than half of the 700,000 Cubans who learned to read and write by December 22, 1961. As part of the second phase of the literacy campaign, the FMC joined the Battle for the Sixth Grade in 1962. Federadas focused on reaching the housewives; they recruited women into the program in door-todoor sweeps. ${ }^{163}$

While Mujeres showed the impact of women's participation through its pages, it also portrayed the vision of a society on the cusp of transformation. However, there were competing visions for what that future would look like. On one page, the magazine presented the ideal of Revolutionary housing projects in the countryside; on the other, it promised a modern, urban future through travel literature about the Eastern Bloc. Scholars note that in the sixties, the Revolution promoted an anti-urban movement of people from the cities to the countryside. ${ }^{164}$ The Havana Greenbelt was part of the antiurban efforts of the Revolution after 1959. In January 1968, Castro delivered a speech to commemorate the completion of 120 homes on the land designated for the Havana greenbelt. ${ }^{165}$ During the speech, he noted that "the countryside will have priority [in

\footnotetext{
${ }^{163}$ Smith and Padula, Sex and Revolution, 85. For more on the Battle for the Sixth Grade; Jaime Canfux and John A. Mateja, "A Brief Description of the 'Battle for the Sixth Grade," Journal of Reading 25, no. 3 (1981).

${ }^{164}$ See Joseph L. Scarpaci, Roberto Segre, and Mario Coyula, Havana: Two Faces of the Antillean Metropolis (Chapel Hill: University of North Carolina Press, 2002).

165 "The climax of this deurbanization process was reached when the giant mobilizations of the sugarcane cutting campaign ensued in the late 1960s." Joseph L. Scarpaci, Roberto Segre, and Mario Coyula,
} 
housing] over the city." ${ }^{" 166}$ Cuban magazines depicted life in the countryside as idyllic after the government built apartment complexes that included public services and entertainment spaces, including child care and movie theaters.

The narratives of Soviet modernity in Mujeres idealized urban life contrasted with the new buildings in the countryside. The magazine portrayed a familiarity between Cuba and Eastern European Bloc countries. Articles took readers on a tour of socialist countries and states of the USSR. The arrival of Soviet films in Cuba led to the establishment of cultural weeks dedicated to showcasing the productions of Soviet states. In 1965 a report from the magazine stated that the USSR was "a mirror of our own future." The report urged readers not to despair when they felt desperation at not having "this or the other." Instead, Cuban women needed to "look in the big and beautiful mirror." The report described the mirror as radiating a luminous future and the image of a friendly nation: the Soviet Union. The pictures that accompanied the story portrayed a thriving city, where children played in parks, and women shopped. A photo of two women looking at a store window adorned with shoes corresponded to a caption with promises of the future: "the Soviet women, also had to endure sacrifice during the first years of their revolution, today they harvest the fruits of their efforts." 167 The magazine encouraged readers to imagine the future of Cuban women through morality tales of Soviet prosperity and modernity.

Havana: Two Faces of the Antillean Metropolis (Chapel Hill: University of North Carolina Press, 2002),141.

\footnotetext{
${ }^{166}$ See Fidel Castro, "Discurso en la inauguración de un pueblo de 120 casas, parte de un plan de más de 600 casas, construidas en 1967, en el Cordón de La Habana, autopista del mediodía, el 6 de enero de 1968," accessed May 2, 2020, http://www.fidelcastro.cu/es/discursos/discurso-en-la-inauguracion-de-un-pueblode-120-casas-parte-de-un-plan-de-mas-de-600-casas.

167 “URSS, Espejo de Nuestro Propio Porvenir,” Mujeres (June 1965): 80-83.
} 
Yet the reality remained, especially in the aftermath of the 1970 harvest, that the Cuban housing problem was far from over and magazines reprinted the stories of the new life Cuban's were forging in their pre-fabricated apartments in the countryside.

Unlike the stories published in the sixties, tales of Cuba's socialist housing projects during the seventies conveyed modernity through descriptions of material culture. Mujeres published articles about housing districts in the countryside, including La Yaya, Birán, and Triunvirato. These were the fruits of Cuban socialism that not only gave those in need housing but also brought Cuban's out of obscurity and into modernity. What did modernity look like inside these homes? Household appliances and electronics lessened the housework and remedied any symptoms of illness for a housewife. In 1974, the magazine announced the new plan for workers to purchase "an article of great utility" for chores: the Aurica 70. The article began as an interview with the washing machine. Readers would learn about the new machine through the conversation and how to use the machine. A household already familiar with the device shared their experience. The wife, Sofia, provided most of the information, while her husband informed the interviewer that he purchased the machine because his wife was sick. Sofia described the device as fast and economical. She recommended the washing machine for any woman who worked, especially those with kids. The article saved the last question for the Aurica: "what do you think of your future job?" The machine replied that it would continue to cooperate with working women so that they could go about their workday with fewer worries and more efficiency. The article about home appliances was unique to Mujeres; no other magazine discussed the use and maintenance of home appliances. The magazine's 
coverage of the washing machine's arrival into the home indicated that modernity, in the form of Soviet home appliances, would improve the lives of women.

The articles profiling Cuban rural housing projects included two specific appliances that distinguished them as modern homes: the refrigerator and the television. An article about a housing district in Triunvirato, Matanzas, described the joy families in rural areas experienced when they received their new apartments. The community, built by workers in the livestock industry, was described as having "modern edifices, magnificent primary school, market, and green areas." Each apartment was assigned a plot of land which families would tend to. The crops from these plots would be distributed amongst all the residents in the future. The magazine stated that this was an example of "a new rural notion where the collectivist sense of the community prevails." The women interviewed in the article recall the struggles they faced in their day-to-day lives before 1959. One of them exclaims that she broke into song and dance when she found out that her new apartment was under construction. Like the other women interviewed for the piece, María González, talked about her new home: "[it] has a television, refrigerator, and if you saw the living room set, beautiful! The boy really likes, apart from the television, his furnished bedroom."168 Likewise, in a piece about La Yaya, the husband excitedly welcomed interviewers inside his home, "come see the television work. Wow, what a beautiful thing! All the houses have a television and a refrigerator."169 While in El Tablón, located in the Escambray Mountains, Rafael Díaz

\footnotetext{
168 “Triunvirato," Mujeres (July 1974): 57-9

${ }^{169}$ Sara González, “La Yaya,” Mujeres (August 1972): 44-7.
} 
described his joy and explained that his wife's fever was cured at the sight of a fully furnished house, "with a television and a refrigerator." 170 The inclusion of electrical appliances in the housing articles corresponded to the adoption of material incentives to motivate Cuban workers after the failure of the Ten-Million-Ton harvest. Previously, the state adopted "moral incentives" to recognize exemplary workers; moral incentives included certificates of recognition, but no material rewards.

Images and descriptions of an ideal home and community in Mujeres were divided between rural ideals and urban visions from the Eastern European Bloc throughout the first two decades. While both portrayals of home assumed a harmonious life, the reality of new living arrangements in the country and the city were a source of daily displeasures. The magazine indicates a constant preoccupation with manners which grew to encompass neighborhood and family dynamics by the second decade. At first, the language regarding manners and behavior did not differ from one decade to another. The articles and advice columns about manners were recycled by the editors of Mujeres repeatedly. This repetition indicates that these were persistent concerns not only to officials but also for Cuban's learning to adapt to new everyday dynamics within the home and in their neighborhoods. In the 1970s, the column "Advice from Grandmother" became "Grandmother Says...," a section that reminded readers that good manners were just as important as learning how to maintain your clothes looking like new. Discussions of good manners ranged from how to behave at a dinner table, to answering the phone, and how to be a good neighbor. The columns on how to behave in private and public

${ }^{170}$ Sara González, “Vida nueva en las montañas,” Mujeres (June 1975): 12-3. 
places outlined the types of behavior officials considered acceptable. For example, the magazine expressed that, "a hello, a smile, [and ] goodwill should be constant norms in our lives as good neighbors." $" 171$ This piece of advice corresponded to a rise in communal living as mass housing complexes provided a mass solution to the housing issues that plagued the country.

Castro recognized the challenges of building apartments in a 1964 speech and explained that families in the countryside did not like the idea of living so close to each other. According to Castro, the idea of living in the apartments left husbands concerned about the women not getting along. Castro admitted that an underdeveloped economy meant that architects needed to think of new ways to find a solution, always keeping in mind that houses had to meet three requirements: be functional, economic, and pleasant. By the late sixties, in the throes of the Revolutionary offensive, construction also slowed, but new construction campaigns in the seventies replaced this.

In 1971 a housing project in East Havana, Alamar, presented Cubans with a new model to obtain a modern, functional, and pleasant home that was also economical for the state. Volunteer construction groups, often assembled by industry and workplace, also known as micro-brigades, helped to speed up the construction of apartment buildings across the island. The agreement amongst co-workers entailed a volunteer group that would dedicate their time to build homes using the materials provided by the state. At the same time, the employees who stayed at the workplace would make up for the absence of

171 “Las Buenas Maneras: Relaciones con los Vecinos,” Mujeres (October 1972). 
the volunteers. Once construction was completed, the homes would be allocated amongst all employees from the workplace (this included those who volunteered and those who stayed at their posts). The vision for Alamar consisted of mass housing for roughly 85,000 families, five movie theaters, twenty-eight child-care centers, eighteen primary schools, and four secondary schools. ${ }^{172}$

\section{SURVEILLING EVERYDAY LIFE}

In 1969, neighbors participating in the Oscar Lewis study explained the social aspects of everyday life for women living in an apartment building. Tomasa Torrente Llanes moved to an apartment building after 1959. At first, her neighbors consisted of people from her previous neighborhood; most of them moved to the same building when the Revolution gave new homes to people living in shantytowns. Torrente Llanes complained about the prefabricated walls that did not block the noises from next door, like the old homes in Havana. She complained about her neighbors, a younger couple, and how their move to the building "completely spoiled everything." Not only were they noisy at all hours of the night, when she complained they were not pleased about her interjection. Torrente Llanes, a federada, knew all about the ins-and-outs of her noisy neighbors, including their illegal trades to buy beer in the black market and the wive's adventures with a young lover when the husband went to away for work. Her complaints extended to the families that moved in at the same time as her. For example, she complained that one of her neighbors is so bad that "she does not say anything; if she

\footnotetext{
${ }^{172}$ Evangelina Chio, "Ellas en la Microbrigadas,” Mujeres (April 1972).
} 
sees a robbery or something bad, she does not say anything because her children are worse." ${ }^{173}$ Not only was her neighbor's son involved with the wrong crowds, but the daughter also offended Torrente Llanes when she did not knock before entering. Stories from other women living in Torrente Llanes's neighborhood reveal that women were primary participants in the surveillance of everyday behaviors.

The closeness between neighbors went beyond the proximity of their homes as the Committee's for the Defense of the Revolution recruited neighbors to complete collective clean up, political study groups, and surveillance. While the FMC dedicated their efforts to expand women's roles in society, the Committees for the Defense of the Revolution (CDR) counted on all members of the Cuban family to defend the revolution. On September 28, 1960, Fidel Castro made a call to action and backed the creation of the Committees for the Defense of the Revolution. The CDRs were initially a response to bombing attacks and the menace of a U.S. backed invasion on Cuban shores. In every neighborhood (one block radius) and workplace, a CDR called upon the masses to take on national defense duties. These duties included surveillance in the form of neighborhood and workplace night watches, the ideological education of neighbors and workers, and the mass participation in production activities outside of the workplace. The CDR's official slogan ("In every neighborhood, revolution!”) conveyed that the protection and defense of the revolution was a part of the neighborhood, and in turn, everyday life.

${ }^{173}$ Oscar and Ruth Lewis Papers (1944-76), Box 180, University of Illinois Archives. 
The organization's magazine, Con la Guardia en Alto, recognized the labor of the neighborhood organizations and helped to mobilize the masses. In 1963, in response to the economic crisis during the first four-year plan, CDRs were tasked with recruiting neighbors to create savings accounts. The Popular Savings Campaign in the CDRs "represent[ed] an enthusiastic backing of the Revolutionary Government's plans." According to the magazine, these savings, once placed in the trusted hands of Cuba's National Banks, would be used to build new factories. In turn, this would create jobs and "increase the country's riches." ${ }^{174}$ CDRs regulated and distributed consumer goods during the sixties in addition to their support of government campaigns. Clothing items, including underwear, were distributed during CDR meetings.

In 1969 the magazine launched a page with letters from its readers and replies from the editorial staff. These letters ranged from general questions to news about accomplishments (individual and group) and requests. In its first response page, editors reminded readers that the magazine was limited to 60,000 copies, which made it challenging to deliver a copy to each household. Editors explained to readers that each CDR president would receive a copy meant to be circulated amongst cederistas in the neighborhood; this was the solution often cited to the challenge of limited circulation. If the president did not have the magazine, it was because it was delivered to "the comrade in charge of the ideological front." ${ }^{175}$ The editor's page was many things at once. Throughout the 1970s, it evolved into a literary forum, where editors gave feedback on

\footnotetext{
174 “Opiniones: A los Comités de Defensa de la Revolución,” Con la Guardia en Alto (1963): 113-4.

175 "Esta es tu página," Con la Guardia en Alto, (December 1969): 11.
} 
stories and poems, as well as a special request section, where requests included artist photographs, music lyrics, and music records. Poems, stories, and songs submitted to the editors were not published on this page. Instead, editors used the page to acknowledge receipt, commend the author, and make evaluations about submissions. Letters in this section indicate a broad readership, from school-aged children to adults.

While the magazine created a space for their audiences to engage with the editorial staff, CDR members also joined census-like activities gathering personal information (names, sex, ages, and license plate, if the family had a car) to help in the distribution of ration cards. This information was used for more than rationing, as active CDR members also assisted in surveillance activities by the Department of State Security. Eulalia Fontanes, the wife of a former CDR president and member of the FMC, recounts how one day a woman came to her house and asked her to help the Department. At first, Fontanes said no because she had children and could not work with the Department of State. The woman insisted: “No, you're not going to come out of your house, they'll go to your house to see you, nothing else. Notice everything that happens in the block. You have to have the census of the full block." With this information, she kept tabs on her neighbors. Fontanes claimed that this activity was outside of the CDR. She also described how the Department of State reached her: a piece of paper arrived with instructions to "attend to this comrade" and "the paper bares the stamp of the CDR of the zone; not from the block." ${ }^{176}$ The CDRs were a pool of surveillance agents that

\footnotetext{
${ }^{176}$ Oscar and Ruth Lewis Papers (1944-76), Box 181, University of Illinois Archives.
} 
authorities could activate at any time. Often these neighbors turned agents were the housewives and FMC federistas, like Tomasa Torrente Llanes and Eulelia Fontanes.

Although the vision for CDRs was of an inclusive experience, individuals in leadership positions could also exclude their neighbors through their jurisdiction to grant and take away organization identification cards. Before a national identification card was established in 1971, neighbors received a carnet from the CDRs. These CDR identification cards proved an individual's everyday participation in defense of the Revolution through activities such as nighttime neighborhood watches; job application's required proof of vigilance and political integration. ${ }^{177}$ The magazine shared a script from an interview with the leadership of the CDR, including national vice coordinator, Omelio Valdés, and provincial coordinators. The purpose of the discussion, previously broadcast on national television, was the new structures and schedules proposed for nightly neighborhood watches. One question from the audiences asked about the repercussions for those "comrades that, using any pretext, always refuse to fulfill their vigilance duties." Omelio Valdés answered that the "correct treatment" for those individuals was to establish "a battle to incorporate them into revolutionary vigilance," and explain the importance of their participation by discussing their duties to protect their locality from enemy intrusions, and the political and economic significance of their participation. When Valdés asked the member of the audience what he thought of the answer, the individual replied, "that is to say, a political treatment." Valdés, agreeing with the reply, also spoke about how CDRs should not behave in the face of a neighbor that did not

${ }^{177}$ Eudelio Pérez, Cuba, ayer y hoy (California: International Windmills Edition, 2011), 78. 
participate: "the identification card should not be taken away from an individual...taking away the identification card would be repressive measure." Valdés qualified that CDR identification cards were not the same as Vigilance Identification Cards and could not serve as proof of completed guard duties; thus, taking away an identification card also meant lowering the membership of the CDR. Recruitment efforts for mass organizations, especially the FMC and CDR, was a duty. Both organizations were tasked with growing their memberships during the second decade as the government required Cubans to volunteer their time and labor in the fields for the Revolutionary Offensive.

Women were important to growing the membership of both organizations. While the FMC focused on women's political and economic integration, CDRs valued the Cuban housewives that stayed at home. In the televised interview Rene Pérez, the provincial coordinator for Pinar del Rio, expressed that "the incorporation of women to vigilance is, without a doubt, of transcendental importance." However, women could not participate fully, and childcare responsibilities were an obstacle for their participation in nighttime watches. Despite these difficulties, Pérez reaffirmed that women could play a decisive role in vigilance activities "from her porch, where she attends to her child and also attends to her duties of revolutionary vigilance." ${ }^{" 178}$ Gradually, the image of a woman, Fefita Comité, personified neighborhood vigilance. One Cuban blogger describes the evening animation:

Every night shortly before $11 \mathrm{pm}$, Cuban Television broadcast an animated short. She was an old lady, fat and nice, like Mrs. Marple. It was called "Fefita Comité,"

178 "El Pueblo Pregunta," Con la Guardia en Alto (July 1969): 20-29. 
[she] organized the guard. She ended [the short] with a tip: "And with your eyes wide open...eh? [...] Over time, people got tired and we began to "miss" the Committee's guard. I remember the story of a bodega robbery. The thieves left a poster: Fefita, you fell asleep. ${ }^{179}$

The women interviewed in the late sixties had an in-depth knowledge of the ins-and-outs of their neighbors and their intimate lives. The fact that the short used the image of an older woman implies that women gained a reputation as the eyes of the CDR.

\section{SOCIAL WELFARE}

Con la Guardia en Alto celebrated the involvement of every member of the family in the everyday activities of the neighborhood and inside homes. These activities not only included neighborhood cleanups, but they also entailed participation in health campaigns. The magazine's cartoon strip featured a young, eager member of the CDR and the activities he completed in salute to the Revolution in his neighborhood. The cederista cleaned the streets, visited a new mom who expressed that she washed her hands frequently, and urged women to complete a cytological test.

In 1971, the magazine published a prize-winning story from one of their writing competitions in salute of the CDR's eleventh anniversary. The story captured how increased interest from officials in sexual health influenced everyday practices and conversations. The story describes the conversations between neighbors as they wait for a meeting to begin. One group of neighbors made up of five women, discussed children, and the conversation evolved into a discussion of the modern contraceptive methods.

\footnotetext{
179 "La guardia del Comité: Con los ojos bien abiertos," Memorias de Cuba (April 23, 2020), Accessed
} May 5, 2020, https://memoriasdecuba.blog/la-guardia-del-comite-con-los-ojos-bien-abiertos/. 
When one of the women claimed that she had a [contraceptive] ring, her daughter interrupted: "What a liar you are, mommy, you always say you have a ring, and I have never seen it!" The author described the adults laughing; this prompted another woman in the group to tell a story about her son. When his classmate asked why he missed the morning's lessons, the boy answered that he accompanied his mom to the local clinic "because she went to put on a ring." 180 The story was part of a growing trend during the seventies to make sexual health a topic of public discussion and education; it also indicated how state control expanded to the control of bodies and reproductive practices.

The FMC made sexual education a priority for their members in the early sixties. However, these discussions were often limited to reproductive education. This meant that the first issues of Mujeres did not discuss sex explicitly. Instead, the editors focused on informing their readers about reproductive organs and the developmental cycle of the fetus. Before sex manuals were printed in the country, the FMC and its publication led the campaigns for sexual education and the legalization of abortion. ${ }^{181}$ By the late sixties, the CDRs joined the FMC's efforts to increase social welfare markers in the country. CDRs led the cytological testing campaign that made women's bodies a public concern and responsibility of her neighbors. The CDR's magazine kept to contraception and cytological tests, but Mujeres expanded its sexual education materials and began to discuss venereal diseases and the psychological effects of intimacy.

\footnotetext{
180 "De esquina a esquina," Con la Guardia en Alto (December 1971): 16-7.

${ }^{181}$ See Emily J. Kirk, "Cuba's National Sexual Education Program: Origins and Evolution,” Cuban Studies 49 (2020): 289-309.
} 
While the social welfare campaigns coincided with the global population control discussion in the seventies, the magazines also discussed a lack of sexual relations as an emotional torment for women. ${ }^{182}$ A 1973 article claimed that "the couples that obtain mutual satisfaction in the sexual act achieve more stable and harmonious interpersonal relationships." The article about frigidity and impotence noted the different factors that impacted sexual appetite in men and women. While it said that frigidity in women stemmed from psychological traumas, it also presented a threat to women's mental/emotional state. According to the piece, "many of the women that do not reach normal sexual enjoyment become neurotic, present pre-menstrual tension and symptoms in menopause." In the case of men, "psychological impotence is specific, not absolute." The article did not mention neurosis as a symptom in the case of men but did advise both sexes to seek psychological counseling and medical advice. ${ }^{183}$

Developments in the education system also made the sexual education articles relevant for mothers sending their children to live and study at the schools in the countryside (ESBECs for its Spanish initials). At the start of the seventies, officials announced a new mass education program that required adolescents to live at their schools in rural areas and away from their families. The schools were a continuation of official's anti-urban attitudes, a source of volunteer labor for agricultural campaigns, and a space where every hour of the day was dedicated to the ideological formation of the new man. Cuba's film industry produced a documentary to showcase the marvels of the

\footnotetext{
${ }^{182}$ See The Unesco Courier (July-August 1974).

183 “Material para los debates de salud f.m.c," Mujeres (February 1973): 94-5.
} 
new schools; the schools counted with laboratories, classrooms, communal lunchroom, basketball courts, pool, and dorm rooms. ${ }^{184}$ But officials could not control everything that happened at the schools and "they needed monks and nuns as professors and students who were converted or about to take up the habits." 185 The articles regarding sexual education in Mujeres concluded with a note about how important it was to share this information, including venereal diseases and contraceptives, with young men and women. ${ }^{186}$ Before the printing of sexual education manuals in the mid-seventies, the FMC's magazine was the only resource, outside of the doctor, for women to learn about sex and all that it entailed. The CDRs continued to track women's visits to the doctor for cytological tests, but it did not include health education in their study circles, that was a job for the FMC and Mujeres.

\section{LEADING BY EXAMPLE}

The CDR and FMC created and promoted campaigns for the beautification of neighborhoods and homes. The CDR focused on gardens with the slogan, "Make Cuba a garden." If a neighborhood CDR wish to receive the title of CDR Garden, all the houses in the neighborhood had to be recognized as gardens. Also, CDR members had to maintain the neighborhood block clean (including the backyards), and turn any space not

\footnotetext{
${ }^{184}$ La nueva escuela (1973), directed by Jorge Fraga.

185 Waldo Acebo Meireles, “Las escuelas en el campo: una continuación,” Cubaencuentro (July 22, 2017), https://www.cubaencuentro.com/cuba/articulos/las-escuelas-en-el-campo-una-continuacion-330090.

${ }^{186}$ Cuban bloggers refer to the German specialist and founder of the National Center for Sexual Education (CENESEX, for its Spanish initials), Mónika Krausset, as the "queen of the condom." She is remembered for saying that girls and boys in the schools "mated like animals." See Carlos Manuel Estefanía, "Sobre las escuelas en el campo de Cuba," El hombre de Cuba nuestra (July 22, 2017), https://cubanuestra1.wordpress.com/2017/07/22/sobre-las-escuelas-en-el-campo-de-cuba/.
} 
under construction into "gardens, micro-parks, areas for children to play, etc."187 Similarly, the FMC created their campaign for the beautification and maintenance of homes three years before the CDR. Like in the CDR campaign, the FMC's Mi casa alegre y bonita/My cheerful and beautiful house, recognized residents for having homes that with a garden and a painted and tidy appearance. Unlike the FMCs campaign, the CDR dedicated their efforts to the first congress of the communist party; the CDR garden campaign would reappear throughout the decade as a drive for noteworthy dates (such as the anniversary of the mass organization). ${ }^{188}$ Popular celebrations were also under the supervision of neighborhood CDRs on historical dates, such as the 26th of July.

In the face of scarcity, the magazines urged their readers to resolver (make-do). In Con la Guardia en Alto, editors shared the experiences of committee members and suggested that neighbors pool their resources. For example, to maintain public spaces and the CDR mural, Adela Martínez detailed how her neighbors borrowed from each other. In conversation with the reporter, Martínez explained that in her neighborhood, they had developed "conciencia" that "we have to find resources ourselves."189 Mujeres also taught women how to make do with resources, but these discussions were framed as economic strategies. The column, "Nuestra Cocina," used economize and make-do interchangeably. Nutritionist and television chef, Nitza Villapol, guided women to create a revolutionary menu with recipes in the magazine. The column not only taught women

\footnotetext{
187 Con la Guardia en Alto (July 1974).

${ }^{188}$ Con la Guardia en Alto (September 1977).

189 “La cuestion es resolver," Con la guardia en alto (November 1973): 12.
} 
how to substitute ingredients, it also influenced Cuban diets and palettes to include more fish and eat with less grease. Both changes, while conveying concern for health, were a reaction to the scarcity of meats and lard. Cuban women applied the advice of mass organizations and made do daily. Yet, where did women, and Cubans, go when they wanted a break from the routine and how did officials seek to control Cuban's experiences of leisure? Once again, mass organizations led the campaigns to provide better service and leisure activities for the population.

The magazine Coctel, published for employees of the National Institute for the Tourism Industry (INIT), indicates that by 1973 the service industry was in decline. Factors that led to the fall included the rise of absenteeism and a lack of qualified service personnel. The same year, during the syndicate's second national congress, INIT declared that all resources would be allocated to the improvement of services to the public. The list of deficiencies shows how discontent and a lack of enthusiasm seeped into experiences at restaurants, cafes, and snack counters:

Bad service and bad treatment.

Stopping services to change shifts.

Serving in "batches."

Not placing all the stock on sale.

Worker's bad personal presence. 
Not keeping the open and close times listed.

Product's sold as packages (requiring customers to buy all or none).

Making users makes different lines.

Slow service.

Low technical education.

Lack of hygiene at units.

Presenting the check to the user before they have finished.

As the inaugural issue noted, "the task of the technical and cultural training of the workers has been ranked [highly] by our government." Thus, the editors identified the need for education in the service industry. Critical to this endeavor, the article noted, were the efforts of "political and mass organizations." Editors also acknowledged that, while these efforts promised to succeed in ridding the industry of bad manners and lousy customer service, "antagonistically, bad work habits that undermine quality arise and spread very quickly." ${ }^{\prime 90}$ Coctel's publication also signaled a renewed effort by officials to control how Cuban's chose to spend their time but also to appease growing discontent. ${ }^{191}$ Cederistas and federadas volunteered in INIT's campaign to improve services: $M i$ trabajo es usted (You are my job). Onelia Méndez, an employee at a Havana Mar-INIT

190 “Existen escuelas de mal servicio?” Coctel (October 1973): 6-8.

191 See Chapter 4. 
dining room, became the girl on the posters. Coctel's editors described Méndez as a hard worker with a "clean appearance and ample smile." The authors of the article mention that as she welcomes them, she hides something in her hands, a sign of her discretion.

In the article, Méndez's every word and action are celebrated as exemplary of the attitude service employees should emulate. Her duties to her home are never mentioned as an issue. However, the magazine later explained that one of the reasons that new efforts were needed in the industry was a lack of understanding of women's positions. Coctel reported that when there was a shortage of service employees at restaurants in the sixties, the FMC brought "a mass influx of women." The editors recognized that this was a failure because there was no formal training program. What was worse than the lousy treatment towards customers? "The inadequate treatment of this new labor force...[and] not taking into account that many times they had to juggle their domestic and labor obligations." 192 INIT worked alongside the FMC to create a training program. They featured women and articles from Mujeres in their magazine; these features often showed women serving tables and smiling. Others showed their skills in baking and the arts. None of the volumes of Coctel housed at the National Library today show women in administrative positions at INIT during the seventies. In 1970 Jorge Risquet, minister of labor, stated that "[women] have to take care of the house, raise the children, and do other tasks along these lines, and this is not easy. From the political point of view, our people would not understand it if we were to treat women and men alike." 193 The words were an

\footnotetext{
192 “Unidades de iniciación y adaptación gastronómica,” Coctel (January-February 1974):14-18.

193 Jorge Dominguez, Cuba: Order and Revolution (Cambridge: Harvard University Press, 1978), 268.
} 
echo of the traditional attitudes but also acceptable in a feminine organization like the FMC's.

\section{CONCLUSION}

Cuban magazines did not linger on the failure of the harvest, and mass organizations, as editors of the emotive repertoire, doubled their efforts to shape everyday experiences. The management of the emotive regime required daily participation, and mass organizations were a vital part of achieving this goal. However, when officials recruited neighbors to spy on one another, it also fostered distrust and unease. Caridad Lastra's feelings in 1969 about life reveal how official management could make daily life feel unbearable: "This place is hell, there is no peace. When you think that you have the best neighbor, he is betraying you. The comite is always fighting in the meetings because they want to set order, and others talk back, but the comité always fights for order."194 These feelings accumulated as the Revolution's emotive regime acquired a strict character throughout the second decade.

Magazines were one of the most effective tools for officials and mass organizations to manage the communal emotions. Their pages reflected a commitment to address women citizens through emotional language and imagery and to educate the masses using the emotional registers of the Revolution. Unbeknownst to the women looking out their window, when they reported their neighbors' activities, they were also acting as emotional managers on behalf of the regime. Overtime surveillance created a

${ }^{194}$ Oscar and Ruth Lewis Papers (1944-76), Box 176, University of Illinois Archives. 
sense of unease and anxiety that officials exploited to suppress actions and feelings threatening the stability of the Revolution. 


\section{CHAPTER IV}

\section{Creating Satisfaction:}

\section{The Contours of Rational Consumption in Cuba}

In 1970, Gloria Morillo described an incident at a Mar-Init cafe in Havana, Cuba:

“One day a young man said, 'I am eating a socialist lunch;' it was a frita and a glass of guarapo. A moreno punched him for what he said, and the street filled up, and the arguing started. Then the young man said, 'You are an extremist, because if you have something to eat it is because you take it (steal it) from someplace...no one has rations here that last until the end of the month.' What he was saying is the reality, but the street was filling up...they took him in the patrol car."195

Gloria was a participant in the Oscar Lewis study about the impact of the Revolution in Cuban society a decade after its triumph. When Gloria explained her perception of modern-day Cuban society, she told it through two stories. The first story, set before 1959, was about a parrot who ended up with a "sewed ass" for speaking too much against Machado. The other was the incident at Mar-Init. According to Gloria, the reactions to the parrot and the young man's words were the same in degree: extreme. She concluded that because of the response to the young man at Mar-Init the current government was a

\footnotetext{
${ }^{195}$ A frita is similar to hamburger; the patty is made up of a mixture of chorizo and ground meat. Guarapo is sugarcane juice. Moreno refers to an individual with dark complexion. Oscar and Ruth Lewis Papers (1944-76), Box 182, University of Illinois Archives.
} 
replica of Machado, "when no one could stand in a corner to say 'Long live Fidel Castro!' It is the same thing because here, he who stands in a corner and says, 'Long live imperialism!' knows he is going down because any extremist shoots him down." Through these examples, she explained why she believed the Revolution did good things but also bad things. Gloria's interview revealed how the tensions between the promises of the revolutionary government and the reality of everyday life birthed skepticism and discord at the beginning of the Revolution's second decade.

While Oscar Lewis's work in Cuban neighborhoods was about more than experiences of consumption, it hints at the central role that consumer culture would play on the island after 1970. The Lewis papers cover a wide range of topics, from life histories to interviews about neighborhood relations. In some interviews, the subjects avoid talking about politics altogether and maintain a positive tone toward any question dealing with the Revolution. In others, such as Gloria's, the participants' perceptions of the state was tinged with cynicism; people were unsure of official's ability to meet people's needs. Consumer goods and experiences were the common denominators that sparked skepticism in these interviews. Discontent and annoyance materialized over rationing, lines at stores, and the desire for consumer goods. Despite these sources of frustration and the consequent skepticism toward the future of consumer culture, people held on to the belief that in 1970 things would change. According to Gloria, by 1970, rice would be sold freely without a ration card: "I have heard that Fidel says it, I have heard people say so." The disastrous state of Cuban consumer culture, coupled with the failure of the 1970 harvest, strengthened the toll that disillusionment would take across production sectors in the seventies. 
Cuba's pre-1959 consumer culture posed a challenge to the Revolution's emotive regime early on. While the state aimed to make Cubans consumers of national products, people's familiarity and preference for American products, along with the economic challenges of the early sixties, did not make it easy. According to historian Michelle Chase, in the first years, the state appealed to women's consumer identities to encourage revolutionary integration. These consumer identities became problematic as Cuba faced new economic challenges. Chase explains that the revolutionary government's positive attitudes toward consumption quickly transformed and labeled the Cuban housewife a threat to the Revolution's progress. Thus, the state defined consumer identity in gendered terms. During the sixties, the state press promoted an image of the problematic Cuban consumer as a middle-aged woman with unrestrained material desires: the housewife. The opposite of the frivolous female consumer of the past was the Revolution's new woman: a young, modest consumer. However, it was difficult to create a modest consumer in the face of shortages. Despite establishing sanctions against hoarding to promote modest consumption in 1960, by 1962, people took to the streets with pots and pans to protest the lack of food in stores. In Cárdenas and Matanzas, women's demands for food reached a fever pitch within months of the state's implementation of a new rationing card system in 1962. After several days, the protests came to a halt when officials sent in military troops and tanks. This sequence of events established consumer complaints as intolerable in the march toward a new Cuban society that required certain sacrifices. The violent reaction to the young man's allegations at Mar-Init was acceptable as it replicated official attitudes toward consumption and mirrored the extreme response to the Matanzas protests. 
In this chapter I argue that the practices of consumption gained particular importance during the Revolution's second decade as an emotive tool that officials could study and employ to create a sense of satisfaction amongst Cubans. Once again, the resources deployed by officials underscore their effective management of the emotive regime. Unlike the expenses of celebrations at the beginning of the decade to create a moment of joy, the efforts to study consumer demand reflect the fact that there was an official emphasis on creating and maintaining a sense of satisfaction. This was not an easy task since consumers also acted as an emotive community that co-existed, adopted, and challenged the emotive repertoires of the regime.

An examination of consumption in the second decade exposes how everyday experiences chipped away at the Revolution's emotive regime. The Oscar Lewis interviews give us an insight into the state of consumer emotions at the beginning of the second decade. Efforts to collect population information also show that the state had similar interests to Lewis in understanding the material culture of the home. Through the scientific development fostered through ties to the Soviet Union, the state recognized the importance of consumer culture and, in turn, the management of affect. The creation of Cuban Institute for Research and Orientation for Internal Demand's (ICIODI, for its Spanish initials) cemented this effort. Despite the work of ICIODI, Cuban consumer experiences did not improve, and people adopted new strategies to voice their dissatisfaction. Letters and phone calls from readers published in the Matanzas newspaper, Girón, embodied the emotive regime's discourse and revealed how frustrations continued to grow despite official efforts to shape demand. This chapter focuses on the Cuban consumer as more than the gendered identity embodied by the 
Cuban housewife, but also as a member of an emotional community whose experiences undermined the Revolution's message of progress. The entries in Girón reveal how the emotive discourses of the regime became the language of complaint; consumer experiences, or lack thereof, cemented Cuba's consumers as a community defined by affect.

\section{OSCAR LEWIS AND THE REVOLUTION'S BLACK MARKET}

In 1968, Fidel Castro invited Oscar Lewis to conduct an anthropological study in Cuba related to his work on the culture of poverty. According to Ruth Lewis, "Castro told her husband that he admired The Children of Sanchez ... saying that it was a revolutionary book "worth more than 50,000 political pamphlets.", 196 In the book, Lewis delves into the markers of urban poverty through the experiences of a family living in Mexican slums. Welcoming Lewis to Cuba was an opportunity to show the positive impact of the Revolution through the work of a respected U.S. anthropologist. Lewis's work created a buzz within his field and attracted the attention of the Cuban revolutionary leader. In an ideal scenario, Lewis would conclude that the Revolution eradicated Cuba's culture of poverty through state-led efforts such as the literacy campaign. In addition, the study would show the erasure of economic inequalities, which implied access to consumer goods and a rise in Cuban's standard of living. The team included Cuban anthropology students at Castro's request. Lewis's team set out to interview urban residents of neighborhoods in Havana. The residents of these neighborhoods were former slum

\footnotetext{
${ }^{196}$ Edwin McDowell, "Did Castro Double-Cross Oscar Lewis?,” New York Times (October 26, 1981), https://www.nytimes.com/1981/10/26/books/did-castro-double-cross-oscar-lewis.html.
} 
dwellers who benefitted from the new housing opportunities and public projects during the 1960s.

Unfortunately, Lewis's study came to an abrupt halt in June 1970 when Cuban authorities confiscated his papers and ordered Lewis, his wife, and a team of U.S. anthropologists to leave the country. ${ }^{197}$ Rumors regarding the real reason behind his expulsion include a dislike for Lewis amongst Castro's advisors, as well as fears that the study was not disproving Lewis's thesis on poverty and instead showed that a culture of poverty remained despite the triumph of the Revolution. It is not clear if Lewis's study was influential in Cuba since his results were not shared with the island's public. However, both Lewis and Cuba's 1970 census surveyed participants about their economic integration, education, and material culture along with questions about housing conditions. ${ }^{198}$ Cuba's census questions echoed those used by Lewis and his team.

The members of Oscar Lewis's team recorded everything that made up the Cuban household, from the family members to the number of socks and forks in their drawers. The object of studying material culture was to understand how the family developed through their "direct knowledge of material objects."199 On July 25, 1969, Paulina

\footnotetext{
${ }^{197}$ Oscar Lewis was able to get field interviews and notes outside of Cuba by mailing them through the Israeli consulate in Cuba. The collection is not complete, but what survived is housed the Special Collections archive at the University of Illinois, Urbana- Champaign. I consulted the Oscar Lewis Collection in May 2018.

${ }^{198}$ Other housing censuses outside of Cuba gathered similar information; it is possible that the JUCEPLAN used the same format. For example, the housing and population census in the United States also tracked the housing conditions (including sewage). However, the U.S. census did not collect information about home appliances.

${ }^{199}$ Oscar and Ruth Lewis Papers (1944-76), Box 183, University of Illinois Archives.
} 
Rodríguez González was asked what she aspired to by one of Lewis's team members. The nineteen-year-old mother began to answer by saying that she liked to go out and have fun, she quickly followed this information by saying that her ultimate aspiration was for her son, herself, and her husband to "estar bien/be well." For Paulina estar bien meant, "vaya, that I do not need anything, to have, when I open my closet, a presentable dress to go to a party, or an aunts house...not go in an old dress like this one." While Paulina made clear that above all she wanted for her son not to need anything, she assured the researcher that her son had clothes and shoes. After her contradictory statement, Paulina reaffirmed that she and her husband still needed clothes. She stressed a personal need for clothing, but behind her account was apprehension about an uncertain future where she might not be able to meet her child's needs. ${ }^{200}$

Although Paulina did not say how she had secured clothes for her child in a market of scarcity, other families revealed that they participated in an active black market that met needs outside of state purview in their interviews. In a material culture report, the investigator recorded his observations of a conversation with Marina Pérez Alonso. Marina tried to explain or excuse why she resorted to black-market activities for her family. The investigator noted that the members of Marina's household who manifested their desire for clothing the most were the two women in the home. Despite this desire, what they frequently complained about was the scarcity of food and the lines that they had to make to acquire goods. Marina expressed that her daughter in law was very familiar with the black market: "anything that she is offered, having the money she will

\footnotetext{
${ }^{200}$ Ibid.
} 
buy it." Thus, the report noted that there were items in the inventory with an elevated price (see table 4.1). The investigator's observations went on to state that, "due to the scarcity in the country for reasons already known, in [Marina's] home, not only do they buy clothes 'por la libre' at a higher price, they also buy food. On one occasion, they paid 39 pesos for four pounds of pork meat, on another forty pesos for ten pounds of cornmeal, and 30 pesos for four pounds of black beans." In 1970, the household of five had a monthly income of 345 to 350 pesos. Almost every month, they employed a substantial sum of money to purchases extra articles in the illegal market. Despite unmet consumer expectations, individuals in the study often expressed gratitude for what the Revolution had achieved and how it had improved their housing situation. ${ }^{201}$ The insights into Cuba's black market from participants in Oscar Lewis's study show that the politics of affection were a daily practice that undermined the politics of passion. Interviews suggest that while Cubans expressed a sense of gratitude for the work of the revolutionary government, they also recognized the need to provide for their families. ${ }^{202}$ At the time, they did not conceive of their purchases as self-consciously ideological. ${ }^{203}$

\footnotetext{
${ }^{201}$ Most subjects in Oscar Lewis's study were members of families residing in new housing developments. 202 Oscar and Ruth Lewis Papers (1944-76), Box 182, University of Illinois Archives.

${ }^{203}$ By the nineties this would change, due to the emotive shifts associated with the Special Period and the proliferation of black-market activities. Anthropologists reveal how everyday Cubans articulate their illicit behavior as separate from their identity. See Hanna Garth, Food in Cuba (Redwood City: Stanford University Press, 2020).
} 
Table 4.1. Information from the Clothing Inventory of Marina's Family

\begin{tabular}{|l|l|}
\hline \multicolumn{1}{|c|}{ Items Purchased in the Black Market } & \multicolumn{1}{|c|}{ Source and Cost } \\
\hline A pair of plastic slippers & $\begin{array}{l}\text { A female neighbor received is as a gift } \\
\text { from her workplace and sold it for 25 } \\
\text { pesos. }\end{array}$ \\
\hline A pair of socks & $\begin{array}{l}\text { Bought from a female neighbor for 20 } \\
\text { pesos. }\end{array}$ \\
\hline A second-hand bicycle & $\begin{array}{l}\text { No provenance; spent 70 pesos. Three } \\
\text { Kings Day gift for child. }\end{array}$ \\
\hline Two coin purses & No provenance; bought for 30 pesos. \\
\hline A baby bottle & $\begin{array}{l}\text { No provenance; bought for 10 pesos. At } \\
\text { the state-owned pharmacy these were } \\
\text { priced at ten cents. }\end{array}$ \\
\hline
\end{tabular}

Source: Oscar Lewis Collection.

Static supply also created cyclical periods of scarcity that pushed the inflation of prices in the black market. In the case of Marina's family, they were willing to buy a baby bottle for the youngest member of the family at an inflated price. Exemplary employees also engaged in the black-market; Marina purchased a pair of slippers from her neighbor that were a token of recognition from the neighbor's workplace (Table 4.1). The black market allowed families to earn an extra income through activities such as selling sweets made from cans of condensed milk. These cans were distributed through the ration cards; the size of the household determined the number of cans. Cans of condensed milk were not the only popular "currency"; sugar, rice, and cigarettes were also bought through the ration card and exchanged between neighbors. The stories collected in the study reveal how the black market helped ease some of the frustrations 
from the static supply, as well as hint at how illicit practices challenged the Revolution's claims that it could meet people's basic needs.

Records expose a pattern of conflict between consumption needs and official discourse at the start of the second decade. In 1970, one household participating in the Lewis project reported that it had been over a year since the last time they had seen butter, rum, or pork in stores (Table 4.2). The dates on which some of these items were purchased are important for understanding how consumer goods, such as butter, could become luxuries and a tool for social control. While some adjusted their diets to exclude butter, others purchased the item through the black market; the static supply made it a luxury. Additionally, the availability of items not considered part of the essential diet on the ration card, such as rum and pork, coincided with important dates on the official agenda. The sale of rum and sweets during October 1968 coincided with the centennial of Cuba's struggle for independence; the sale of pork that December also coincided with the tenth anniversary of the Revolution. Similarly, at the 1970 Havana Carnival, when Castro declared that the efforts to complete the harvest were not enough, beer, an item rationed by the state, flowed freely. There was a pattern in which the state made coveted consumer goods available around commemorative dates. 
Table 4.2 Goods Purchased at State- Owned Stores, 1968 - 9169

\begin{tabular}{|l|l|}
\hline \multicolumn{1}{|c|}{ Items Purchased in State Store } & \multicolumn{1}{c|}{ Last Date Available at State Store } \\
\hline Butter & August 1968 \\
\hline Soap and Detergent & April and May 1969 \\
\hline Rum & October 1968 \\
\hline Floor mop & October 1968 \\
\hline Sweets & October 1968 \\
\hline Guava bars & April 1969 \\
\hline Pork & December 1968 (expected again in July, 1970) \\
\hline
\end{tabular}

Source: Information from an interview in Oscar Lewis Collection (Box 182), dated February 23, 1970. The year 1968 not only marked the beginning of the Revolutionary Offensive that culminated with the failure of the 1970 harvest, it was also the tenth anniversary of the Revolution and the Centennial of Cuba's struggle for independence.

State officials promised Cubans that the sacrifices made in the name of the Revolutionary Offensive would be rewarded; participants in the Oscar Lewis study shared a belief that after 1970 the availability of consumer goods could only improve. Unfortunately, Lewis was not able to record the reactions to the failed harvest from the participants in the study. Despite not being present for the aftermath of the Ten-MillionTon harvest, Lewis captured the emotional turmoil Cuban's experienced at the beginning of the Revolution's second decade. The failure of the harvest exacerbated tensions between the promises of Revolution and the realities of everyday life.

\section{CUBA’S FIRST REVOLUTIONARY CENSUS}

The first state-planned, scientific endeavor to collect information on Cuba's population after 1959 began a decade before ICIODI's founding. The Central Planning Board (JUCEPLAN, for its Spanish initials) was founded in 1960, under law 757, to assist in the development of a Cuban economic path that aligned with the objectives of the new government. According to the official decree, JUCEPLAN would "set, guide, 
supervise and coordinate the economic policy of the different organs of the state and autonomous entities." 204 To carry out its functions, the Central Planning Board counted on a technical secretariat department that would gather and supply the administrative leaders with the necessary information. This information consisted of statistical reports, including information that would dictate not only state economic initiatives but also the cultural and social life within Cuba. The board became fully operational with the aid of Czechoslovakian experts and, by 1961, began to conduct experimental data collection activities. $^{205}$

Throughout the first decade of the Revolution, JUCEPLAN would play a central role in developing the first four-year plan (1962 to 1965). The plan emphasized investing in the industrial sector, especially heavy industry. The plan for rapid industrialization remained an unfulfilled vision, and Cuba entered an economic crisis by 1963 . Che Guevara, then president of the national bank and minister of industries, acknowledged "some of the errors" including "[finding] out later that [many industrial plant's] technological efficiency, in international comparative terms, was low, and their net effect on import substitution was limited since the raw materials needed also had to be imported." ${ }^{206}$ Despite the unsuccessful four-year plan, state organs and officials

\footnotetext{
${ }^{204}$ José Bell Lara, Tania Caram León, and Delia Luisa López, Documentos de la Revolución Cubana, 1960 (La Habana: Editorial De Ciencias Sociales, 2008).

205 "National Experience in the Formulation and Implementation of Population Policy, 1959-1976," United Nations Department of Economic and Social Affairs (1977).

${ }^{206}$ Some scholarship has focused on the environmental impact of socialism in Cuba. See, Sergio DíazBriquets and Jorge F. Pérez-López, Conquering Nature: The Environmental Legacy of Socialism in Cuba (Pittsburgh: University of Pittsburgh Press, 2000), 41.
} 
continued to rely on the work of the Central Planning Board. In 1963, as a reaction to the shortages of cooking lard and oil, the JUCEPLAN carried out a census-like survey to count the household units in regions of the country. This survey was used to develop a rationing system for consumer goods that included rationing cards for Cuban households. $^{207}$

Although JUCEPLAN was established with the purpose of collecting and disseminating demographic data, it took over eight years for the planning board to tackle a large-scale data collection activity: a population census. In 1963 the office worked on trials gathering population information in three Havana neighborhoods. From these experiences, the plans to conduct a national census were postponed due to a lack of personnel with adequate training. ${ }^{208}$ It would take an additional four years before JUCEPLAN began establishing the necessary conditions for collecting population and demographic information across the country. In 1967, after a seven-month course titled "Census Formation", the census personnel carried out a trial run in the municipality of San Antonio de los Baños. This trial run resulted in adjustments to the methodology and was followed by a second trial in Pinar del Río in $1969 .{ }^{209}$

Like the Ten-Million-Ton harvest, the mobilization relied on volunteers and called upon Cubans to participate in reaching yet another benchmark for the Revolution.

\footnotetext{
${ }^{208}$ Carlos Villarroal Sandoval and Ernesto Chávez Álvarez, Las estadísticas demograficas cubanas (Havana: Editorial de Ciencias Sociales, 1975).

${ }^{209}$ After the first trial, JUCEPLAN noted that it was necessary to register housing and their occupants to divide zones into sectors.
} 
Following the second trial, JUCEPLAN conducted a two-month seminar for regional delegates. The delegates were chosen based on their "level of education, experience in an administrative position, and good health." ${ }^{210}$ Municipal delegates traveled to Havana for a fifteen-day course during February 1970. Around 2,000 university students participated in the municipal course; they would act as sub-delegates at the municipal level.

Supervisors were trained at the municipal level during a three-day seminar. Some provinces offered a one-day seminar for enumerators, while television and radio served as educational tools to reach a broader audience of volunteers. The prologue to the final census report noted, "the importance of this seminar by radio and television since it maintained the uniformity of criteria in the explanation to the base because the technicalcensus personnel of JUCEPLAN dictated it." ${ }^{211}$ Three major groups made up the volunteers: teachers, students, and workers. Most of the supervisors were teachers, while the enumerators consisted of students and workers. The week before volunteers would take to the streets for the first Revolutionary census broadcasts of the enumerator seminar were repeated over four days, during the morning, noon, and evening. ${ }^{212}$

On September 6, 1970, just over a month after Carnival's return and before Varadero's music festival, the Cuban government immobilized the masses. The census required collaboration from the entire Cuban population; thus, the census's success relied on the intervention of the state. In urban areas, transportation services were suspended

\footnotetext{
210 Junta Central de Planificación, Censo de Población y Viviendas, 1970 (Havana: Obre, 1975).

211 Junta Central de Planificación, Censo de Población y Viviendas, 1970 (Havana: Obre, 1975).

212 Along with the census, participants were given a temporary number which would eventually become the standardize form of identification in the country: carnet de identidad.
} 
from 8 a.m to 4 p.m. to ensure that people stayed at home on census day. Transportation was not the only service suspended in the immobilization efforts, shops and markets were closed, and the distribution of milk and bread was limited to Saturday. The only services which would remain open on the day of the census were pharmacies, funeral homes, and cemeteries. ${ }^{213}$ Volunteers had one day to collect information in urban areas and three days in rural areas. The census activities echoed the mass mobilization of the TenMillion-Ton harvest.

Official press coverage of the event portrayed the census as a momentous occasion that required a heightened sense of moral duty. With phrases such as "quality answer... Quality census!" the national and local state press brought to their reader's attention the importance of their cooperation and what to expect when the enumerators visited their homes. ${ }^{214}$ The Cuban media published instructional material about the census, and why the information was important, how it compared to previous statistics and how it would be different. According to one magazine spread, this would be the first census carried out by Cuban technicians in the history of the country, following the 1940 constitution's decree that censuses would be carried out every ten years. ${ }^{215}$ The article detailed the roles of enumerators and household members and how people should behave

\footnotetext{
${ }^{213}$ Store and market closures were mandatory except in special cases in which they would open from $5 \mathrm{a} . \mathrm{m}$ to 7 a.m. on September 6. In the case of bread and milk, only if necessary, they would be distributed on Sunday until 7:00 a.m. "En Cuba: La Marcha Organizativa del Censo," Bohemia (September 4, 1970): 64.

214 “6 de Septiembre Censo de Población y Viviendas,” Bohemia, (September 4, 1970): 50-57.

${ }^{215}$ Also noted in the article is the reason why censuses should be conducted in years that end in zero, based on the historical origins of the census in ancient China and Rome. "Bohemia Económica: Algunas preguntas y otros datos, que beneficios rendira el proximo censo?," Bohemia (August 7, 1970): 28-33.
} 
in each instance to answer the questions on the form. Cubans were asked to open their doors to the enumerators "without the slightest reservation." 216 In case of resistance or difficulty, enumerators were instructed to "exhaust all persuasive resources." 217 The day of the census, thousands of volunteers took to the streets for the first population census in Cuba since 1953 (Table 4.4).

After the census, the state news agency, Prensa Latina, reported on the experiences from Havana's "480 minutes of solitude." The title referred to the mass mobilization through the eyes of a reporter following the enumerators and walking through empty streets of Havana; the article was published in the national magazine, Bohemia, the week after the census mobilization was completed. ${ }^{218}$ The narrative began with likening the sight of Havana to a deserted town in an old Western movie on the morning of Sunday, September 6, 1970:

"The city dawned deserted...on the doorsteps of all the houses, the silhouettes of Havana residents: they waited for their enumerator...there was everything: "relax" and solemnity, small intimate dramas and tragicomic incidents. This is the balance: an immobilization that implied, paradoxically, an intense and incessant popular mobilization. The activity was carried out with the precision of a military maneuver."219

\footnotetext{
216 “6 de Septiembre Censo de Población y Viviendas,” Bohemia (September 4, 1970): 51.

217 “En Cuba: La Marcha Organizativa del Censo,” Bohemia (September 4, 1970): 64.

${ }^{218}$ Prensa Latina was established in 1959 as the official press agency of Cuba. The agency was/is responsible for reporting on all government activities, including speeches.

219 “480 Minutes of Solitude,” Bohemia (September 11, 1970): 88-89
} 
The quiet of the streets described in the introductory paragraph was broken by the presence of a young man asking an older woman to open her door at her house. The character of the woman modeled the expected behavior of citizens as she yelled down that she had been waiting for him. In another moment from Havana's "minutes of solitude," the journalist describes the enumerator, a young volunteer. The enumerator "could be black or white (almost always a youth less than twenty-five years of age)...[He is] ready to fight the battle of the census ... in hand, besides the required weapons (forms, cards, pencils, and pens) a small, but well assorted, plastic backpack: his campaign diet." ${ }^{220}$ In another snapshot, the article described how the census accounted for people from all backgrounds, emphasizing that there was no class difference. The last snapshots emphasized the importance of the duty to complete a revolutionary task. A man's emotional appeal did not dissuade the volunteer from following the orders of the day. When the volunteer encountered a man crying about his housing situation, separated from his wife he was caught wondering the empty streets of Prado without the correct permit. The volunteer apologized ("I'm sorry as a man") and detained the crying male, "in the gentlest and fraternal manner you can imagine." The piece concluded with the story from the maternity ward where a woman delivered a 5-pound baby boy. Still, the father was not present because he was fulfilling his volunteer obligations for the census. These stories were the ideals of exemplary Cuban participation in the momentous mobilization toward the census. From the enumerator "armed" with the essentials to the woman delivering a baby in the absence of her enumerator husband, the stories celebrated the

220 “480 Minutes of Solitude,” Bohemia, September 11, 1970. 88-89 
collaboration and dedication of Cubans. The message embedded in these snapshots presented that nothing was more meaningful in meeting a Revolutionary task than mass compliance and participation.

Table 4.4. Volunteers Engaged in Collecting Census Data on September 6, 1970

\begin{tabular}{|l|c|c|c|r|}
\hline \multicolumn{1}{|c|}{ Province } & Supervisors & Enumerators & Other & \multicolumn{1}{c|}{ TOTAL } \\
\hline CUBA & $\mathbf{2 1 , 5 4 5}$ & $\mathbf{1 4 3 , 6 0 3}$ & $\mathbf{1 7 , 2 0 8}$ & $\mathbf{1 8 2 , 3 5 6}$ \\
\hline Pinar del Rio & 1,152 & 6,729 & 945 & 8,826 \\
\hline Havana & 6,178 & 52,472 & 5,183 & 63,833 \\
\hline Matanzas & 1,373 & 9,699 & 1,738 & 12,810 \\
\hline Las Villas & 3,605 & 21,699 & 2,391 & 27,695 \\
\hline Camagüey & 2,734 & 14,755 & 1,898 & 19,387 \\
\hline Oriente & 6,503 & 38,249 & 5,053 & 49,805 \\
\hline
\end{tabular}

Source: Censo de poblacion y viviendas, 1970 (1975).

Although the census was about mass immobilization, a lack of enthusiasm continued to affect the population, and calls for volunteers did not arouse the same mobilization as previous causes. The absenteeism thatplagued Castro's speeches during the harvest continued; there was a palpable decline in the Revolutionary zeal that mobilized the masses in the past. The numbers reported in the state press and the official census report were contradictory. While Bohemia estimated that around 300,000 volunteers helped to record the information, the national newspaper, Granma, reported that it took 286,430 volunteers to complete the census. In the 1970 census's final report, the number of volunteers totaled 182,356 . The press reported a higher number, rendering the image of robust and large-scale participation. The last number of volunteers in the 
census indicates that although a mass-immobilization and volunteer task were accomplished, this did not mean that people were moved to participate in large numbers to advance the goals of the Revolution.

\section{THE STATE OF CUBA MATERIAL IN 1970}

Notwithstanding the different participation numbers, the census was a historic occasion for the development of a planned economy. Not only did the census identify the demographic markers of Cuba, it also took stock of the socio-economic conditions of Cuban households, including their source of water and light, and the state of kitchens and bathrooms. However, what made this census stand out from prior Cuban censuses were the questions regarding home appliances. From televisions to sewing machines, the census recorded if the equipment was in working order or broken, and the number of family nuclei and individuals with access to these (see Table 4.5).

The information on housing was important because it was not only an issue that pre-dated the triumph of the Revolution but also one that would continually place into question the Revolution's progress. In the sixties, efforts to build housing stalled due to experimenting with different construction methods; by the seventies, the state attempted new construction strategies, including construction micro-brigades. ${ }^{221}$ Information collected not only confirmed that the Revolution had fulfilled some of its initial promises, such as raising the literacy rate, but it also highlighted areas lacking progress, such as housing and women's incorporation into the nation's labor force (see Table 4.6). The

\footnotetext{
${ }^{221}$ See Manuel Cuadra, Aspiraciones y espacios de una Revolución: Arquitectura y urbanismo en Cuba 1959-2018 (Germany: Kassel University Press, 2019).
} 
final census results reflected some of the material and social realities that, along with housing, would continually challenge the Revolution's message of progress. ${ }^{222}$ Women made up 22 percent of Cuba's economically active population and 71 percent of the economically inactive population. There were more housewives than employed women; this was an issue for production goals. The report echoed the situation during the early sixties, where a gendered understanding of consumer culture prompted the revolutionary government to embrace the role of the housewife as the consumer for the family. As mentioned earlier in the chapter, this positive attitude quickly turned to suspicion.

Table 4.5 - Cuban Population and Housing Census, 1970

\begin{tabular}{|c|c|c|c|}
\hline \multicolumn{2}{|r|}{ Equipment } & Census Nuclei & Persons \\
\hline \multirow{5}{*}{ 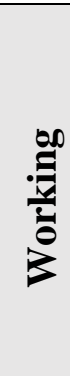 } & Radio & 867,891 & 3866,469 \\
\hline & Television & 166,521 & 700,066 \\
\hline & Ice Box & 31,938 & 63,659 \\
\hline & Refrigerator & 404,651 & $1,649,707$ \\
\hline & Sewing Machine & 685,102 & $3,244,933$ \\
\hline \multirow{2}{*}{$\begin{array}{l}0 \\
\frac{0}{0} \\
0\end{array}$} & Radio & 298,617 & $1,405,578$ \\
\hline & Television & 154,179 & 624,576 \\
\hline
\end{tabular}

\footnotetext{
${ }^{222}$ The results from the 1970 census do not often appear in recent scholarship. It is true that these numbers must be treated with skepticism due to several factors, including the roles of human error and the pressure to meet data collection goals. The census required a second round in which enumerators collected the data to account for errors in the first mobilization. The results were left unpublished until 1975. Although one must take caution when it comes to production amounts, the population census contains valuable data. While people might lie about their birthplace, or country of provenance, the questions about the conditions of the home and the electronic devices did not have official incentives (such as moral or material) or detractors (such as political or criminal penalties) that would influence people to claim better or worse conditions (for example reporting a higher number of electronics in good condition versus those in disrepair). This does not mean that people were not compelled to lie in hopes of a material reward. Personal accounts mention that at the time some assumed that the reason for reporting domestic appliances was related to a state plan to distribute home appliances in the future. Despite these assumptions, there were no official announcements linking census activities with material incentives.
} 


\begin{tabular}{|l|l|r|r|}
\hline \multirow{2}{*}{ Ice Box } & 131,86 & 52,243 \\
\cline { 2 - 3 } & Refrigerator & 47,341 & 208,611 \\
\cline { 2 - 4 } & Sewing Machine & 75,591 & 388,903 \\
\hline Not declared & 368,536 & $1,611,800$ \\
\hline
\end{tabular}

Table 4.6 Cuban Population Not Economically Active by Category

\begin{tabular}{|c|r|r|r|r|r|}
\hline \multirow{2}{*}{ Census Categories } & \multicolumn{2}{|c|}{ Gender } & \multicolumn{2}{c|}{ Region } & \multirow{2}{*}{ Cuba } \\
\cline { 2 - 5 } & Female & Male & Urban & Rural & \\
\hline Housewife & $1,513,933$ & 33,131 & 937,426 & 579,820 & $1,517,246$ \\
\hline Student & 518,166 & 578,194 & 647,035 & 449,325 & $1,096,360$ \\
\hline $\begin{array}{c}\text { Other Housework } \\
\text { Domestic service and } \\
\text { related services }\end{array}$ & 356,433 & 5,402 & 197,669 & 164,166 & 361,835 \\
\hline $\begin{array}{c}\text { Retired/Pensioner } \\
\text { Physically disabled }\end{array}$ & 65,086 & 213,619 & 198,148 & 80,557 & 278,705 \\
\hline $\begin{array}{c}\text { Over labor age and in } \\
\text { asylums }\end{array}$ & 46,194 & 114,919 & 105,649 & 55,464 & 161,113 \\
\hline Other Situation & 12,861 & 54,029 & 46,164 & 20,726 & 66,890 \\
\hline
\end{tabular}

Source: Censo de poblacion y viviendas, 1970 (1975).

In the case of the economically inactive population, the numbers show that 41 percent of the total population were not considered economically active; this number included students, housewives, elderly, and disabled persons. The 1970 census results 
reflected a larger concentration of people in urban areas; in the country, the most significant number of inhabitants were children (under one to 14 years old), youth and young adults (15- 24 years old), and adults under the age of forty-five. A little over 30 percent of the population was economically active, meaning that they worked outside of the home. Between men and women, men made up the majority of the economically active population.

Official reports, such as the 1970 Population Census, are not reliable, but they are useful. Bohemia's coverage of the census and the different numbers of volunteers showcase the unreliability of official figures and how these could easily be adjusted to portray an ideal vision of the state. However, the census remains a valuable form of information, perhaps not for its numbers but because of what the data collected suggests regarding official interest. The portion of the census that focused on the state of appliances and domestic goods suggests that part of the emotive shift in the second decade required officials to take stock of the material culture of everyday life.

\section{LOS SOVIETS, ICIODI, AND RATIONAL CONSUMPTION}

Official efforts to collect data about the population included more than the planning and execution of the 1970 Population and Housing Census. The failure of the 1970 harvest also coincided with a growing interest within JUCEPLAN to collect a broader set of data to measure and understand the development of Cuban society. In April 1971, JUCEPLAN gathered experts from the social sciences and tasked them with studying the characteristics and challenges of identifying and analyzing demand in Cuba. Leaders of the Cuban Institute for Research and Orientation for Internal and Demand's (ICIODI, for 
its Spanish initials) envisioned the center as an intermediary, working "to shape rational consumers and make peoples consumption more scientific.” By 1970, Cuban housewives continued to constitute the majority within consumer groups. Still, unlike the previous decade, the work of ICIODI shifted the focus from gender to include a scientific perspective (that would evolve into studies on the economy of time). Researchers conducted surveys, from hours spent doing house shores to fashion, to understand the science behind Cuban consumer practices. Eugenio R. Balari, president of ICIODI, described that "the fundamental object of the socialist society is related to the satisfaction of the population's material and cultural needs, from there is where these investigations gain their importance for revolutionaries and communists." ${ }^{223}$ Thus, the revolutionary government relied on ICIODI's studies to support the advancement of socialist goals.

During its early years, ICIODI's experts counted on their counterparts from the Eastern bloc to set the course of their work. While ICIODI sent specialists to western European nations, they relied primarily on the guidance of Soviet technicians and their experiences. The Eastern bloc had a strong presence at the center; the USSR sent two economists and four staff members from Hungary's Institute of Market Research led conferences on the market and predicting demand. While ICIODI delegates traveled to Paris and England for conferences and technical courses, about a dozen of the institute's staff completed courses in the USSR. The institute also sent delegations to Eastern Bloc countries "to get to know more homologous institutions."224 Travel itineraries from 1973

\footnotetext{
${ }^{223}$ ICIODI, Investigaciones cientifícas de la demanda en Cuba (1979), 16.

${ }^{224}$ Ibid., 13.
} 
to 1975 included visits to Hungary, Poland, RDA, Bulgaria, Romania, Czechoslovakia, and the USSR. During their travels through the Eastern bloc countries, ICIODI delegations visited their institutional counterparts to study their functions and establish collaborations. By 1974, the center had a presence in two meetings of the European Society for Opinion and Marketing Research (ESOMAR) and the World Conference on Industrial Design held in Moscow.

In June 1975, a year after joining the Council for Mutual Economic Assistance (COMECON), Cuba hosted the International Seminar on Market Demand. ${ }^{225}$ The majority of the countries visited by the Cuban institute's delegations sent representatives to the seminar. Balari recognized the influence of the All-Union Scientific Research Institute for Studying Demand for Consumer Goods and the State of Trade (VNIIKS). VNIIKS played a central role in the development of Soviet consumer culture. According to Soviet historian, Natalya Chernyshova, "the purpose of VNIIKS was to oversee and consolidate the gathering of information on consumer demand across the country and to advise both trade and industry." 226 Thus, VNIIKS was a model for ICIODI.

\footnotetext{
${ }^{225}$ In 1972, Cuba formally entered the Council for Mutual Economic Assistance (COMECON) and by 1976 the country declared its first five-year plan. Census information was important to the state building projects throughout the decade, especially the first five years. In 1971, a year after the census, Cuba would begin the practice of adopting the Soviet economic model predating Gorbachov, dubbed the System of the Direction and Planning of the Economy (SDPE). The Sistema de Dirección de la Economia (SDPE) was the economic program adopted by Cuba from 1976 to1985. See Sergio G. Roca. "State Enterprises in Cuba Under the New System of Planning and Management (SDPE)" (Cuban Studies 16, 1986): 153-79; Carmelo Mesa-Lago, Market, Socialist, and Mixed Economies: Comparative Policy and Performance: Chile, Cuba and Costa Rica (2000).

${ }^{226}$ VNIIKS was founded in 1965 under the direction of the State Committee for Trade. See Natalya Chernyshova, Soviet Consumer Culture in the Brezhnev Era (New York: Routledge, 2013).
} 
The Soviet institute not only welcomed ICIODI to its offices in the Soviet Union, but it was also crucial in guiding and supporting the development of the Cuban institute's activities. In Balari's opening remarks at the center's first International Seminar on the Scientific Research of Demand, the president recognized Soviet technical aid. The seminar showcased and celebrated five years of work completed by the institute's experts. The presence of both Soviet and Eastern bloc experts was central to the development of the institute during those five years. Balari credited the work of comrades G. Korovkin and Nicolai Kuznetsov, both doctoral candidates in economics at the time, in identifying viable methods for studying demand in Cuba, given the country's "socioeconomic peculiarities." 227 Seminar papers repeatedly cited the work and seminar interventions by the Soviet doctor in Economics, Ian Lindberg. When the ICIODI published conclusions from the seminar in 1979, the bibliographies confirmed the influence of Soviet scholars and research; this included Lingerg's recommendations for Cuban short- and long-term distribution norms.

The Cuban experts, like their Soviet counterparts at VNIIKS, were interested in understanding the relationships among demand and production, distribution, and consumption. ICIODI's team identified six subject areas for studies from 1971 to 1976: rationing, products and services, consumption habits, wages and expenses, gastronomy, and nutrition. Each area had a goal to inform and guide the work of the institute and its experts (Table 4.7). Research projects under each subject area integrated a variety of

\footnotetext{
${ }^{227}$ Natalya Cheryshova, Soviet Consumer Culture in the Brezhnev Era, 7.
} 
methods, but the most popular resource were surveys developed as part of social psychological investigations.

Table 4.7 Areas of Interest Outlined by ICIODI (1971-1976)

\begin{tabular}{|c|c|}
\hline Subject Areas & Goals \\
\hline Rationing & $\begin{array}{l}\text { Study rationing systems in other countries } \\
\text { to achieve "flexibility in the distribution } \\
\text { of products and the provision of services } \\
\text { to the population." }\end{array}$ \\
\hline Products and Services & $\begin{array}{l}\text { Studies ranged from furniture to time. The } \\
\text { goal of studying these was to reach a } \\
\text { better understanding of people's needs and } \\
\text { how these fit into "the realities of our } \\
\text { economy." }\end{array}$ \\
\hline Consumer Habits & $\begin{array}{l}\text { Study use of goods and consumer } \\
\text { preferences, so they are taken into } \\
\text { consideration in the future production } \\
\text { plans of the consumer goods industry. }\end{array}$ \\
\hline Wages and Expenses & $\begin{array}{l}\text { Study the wages, expenses, and } \\
\text { employment of free time in the Alamar } \\
\text { community to develop long and short- } \\
\text { term production plans. }\end{array}$ \\
\hline Gastronomy & $\begin{array}{l}\text { Study the community dining halls in } \\
\text { workplaces and schools and the design of } \\
\text { gastronomic units to increase knowledge } \\
\text { of the different service sectors that "tend } \\
\text { to improve the social consumption of the } \\
\text { population." }\end{array}$ \\
\hline Nutrition & $\begin{array}{l}\text { Study nutrition habits to plan orientation } \\
\text { campaigns. }\end{array}$ \\
\hline
\end{tabular}


Although the institute claimed six focus areas, a seventh area evolved to include "complementary studies." These complementary studies focused on the histories of consumer goods and the population. Of specific interest for the institute was the evolution of clothing, dining sets, and kitchens. Some studies quickly became part of social welfare campaigns. For example, studies on gastronomy were used to develop a food culture campaign. The campaign would "educate" people on which foods to purchase based on their nutritional value. Ultimately, it would "promote the modification of some traditional habits of consumption." In this case, taste for pre-revolution foods was not the issue; instead, ICIODI experts defined the problem as "prejudices resulting from underdevelopment." ${ }^{228}$ One example of these prejudices used by the experts was the popular opinion amongst Cubans that pork meat harmed sickly people. The food culture campaign aimed to erase these prejudices; it also attempted to increase the amount of fish in the Cuban diet. On the other hand, experts labeled Cuban's concern with clothing as part of cultural neocolonialism in which the national culture fought not to fall into the American way of life. In the analysis, clothing became an irrational habit of ostentatious consumption. Experts concluded that ideas about dress were rooted in the years of the mediated republic. Lastly, they explained that clothing problems were more severe than nutrition because of the social weight implied by dress and the "classist seal of international fashion." ${ }^{229}$ The complementary studies developed to inform the main

\footnotetext{
${ }^{228}$ ICIODI, Investigaciones Cientificas de la demanda en Cuba (1979).

${ }^{229}$ ICIODI, Investigaciones científicas de la demanda en Cuba (1979).
} 
subject areas as part of the institute's drive to use a variety of approaches, from history to anthropology, to understand consumption.

\section{THE EMOTIVE REGIME'S RATIONAL CONSUMER}

While ICIODI staff were encouraged to explore methodologies used in the social sciences, the institute was part of a higher goal to advance Cuba's socialist progress. Seminar participants quoted Engels, Marx, and Fidel Castro interchangeably to define and support their research. The words of Cuban leaders, such as Fidel and Raúl Castro, reiterated the importance of ICIODI's work about official ideology. Fidel Castro's address at the First Congress of the Communist Party of Cuba in 1975 became a mantra at the ICIODI seminar the following year:

"We must never stimulate the spirit of waste, the selfishness of possessing what we do not rationally need, the vanity of luxury, and the insatiability of desires. Never fall into the vulgar mentality and stupid vanities of capitalist consumer societies, which are ruining the world."

Our duty is to concentrate our energies and our limited means...ensure the progressive improvement of the material and cultural base of our people, and that will also allow us to think, act and fulfill our duties as citizens of a new world. ${ }^{230}$

ICIODI experts used the words of Karl Marx and Frederic Engels in their proposal for Cuban's to practice rational consumption. Both wrote about the relationship between production and need. According to Marx, for something to be a rational need, it

\footnotetext{
${ }^{230}$ First Congress of the Communist Party of Cuba, Central Report, (Havana: Department of Revolutionary Orientation of the Central Committee of the Communist Party of Cuba, 1975): 94-95.
} 
must benefit the majority; therefore, rational consumption required that consumers ignore individual desires.

Cuba's new man and woman of the Revolution were familiar with the ideals of the politics of passion and sacrifice, but how would this translate to their consumer experience in the seventies? Experts cited Engels to reinforce the idea that a planned economy would lead to "the satisfaction of all of [society's] rational needs." ${ }^{231}$ The emotive regime endorsed rational consumption practices. Rational consumption took control away from the consumer, as these needs no longer defined demand. Instead, scientific norms would determine the productions of goods and services within a planned economy if Cubans became rational consumers, the scientific work of ICIODI guaranteed satisfaction. Although it implied satisfaction, rational consumption did not ensure that officials could meet the needs scientifically identified by ICIODI.

\section{"ESPERO UNA SOLUCIÓN NO UNA JUSTIFICACIÓN”}

In 1972, a Cuban delegation, including Fidel Castro, traveled to Bulgaria. During the visit, the delegation toured production centers and met with Bulgarian leaders. Notes from the Bulgarian officials assessed Cuba's socialist progress:

"Since comrade T. Zhivkov's visit to Cuba the positive process continues but the problems remain the same. The tempos of the economic development on the main indices and in the basic branches are very low- about 2-3\% growth. And it seems that there is no real planning. It is said that it would be done but it is carried out

${ }^{231}$ ICIODI, Investigaciones científicas de la demanda en Cuba (1979), 59. 
slowly and it is not felt like something very important in the construction of socialism. Similar things can be pointed out about the leading role of the party, about the bodies of the proletarian dictatorship, about the material interest and others." 232

While ICIODI established relationships with its Soviet counterpart and conducted small-scale surveys in Alamar within the first five years of its creation, Cubans' consumer experiences followed the patterns created in the sixties. Long lines, rationing, and shortages were a part of daily life, especially for Cuban housewives. However, unlike the housewives of the early sixties and those interviewed by Oscar Lewis, by 1974 , Cubans turned the Revolution's words into demands.

On December 24, 1974, Matanzas's provincial newspaper, Girón, revealed to its readers a new section: Apartado 133. The newspaper called upon their readers to send their "criticism, suggestions, initiatives, and comments on the work of the province in general." Matanzas launched the pilot Poder Popular (Organs of Peoples Power, OPP) eight months earlier. Creating a public space for its readers fit into the culture of OPP. Institutionalization required people's participation in all aspects of administration. It also required that everyone hold each other accountable for their role in achieving the goals set forth by the revolutionary government. Therefore, when Girón editors asked the residents of Matanzas to share their thoughts on the work of the province, this included the work of stores, employees, managers, and the OPP. Within two days of Girón's

232 "Report on Fidel Castro's Visit to Bulgaria and Bulgarian-Cuban relations," May, 1972, History and Public Policy Program Digital Archive, Central State Archive of Bulgaria (TsDA), Sofia, Fond 1-B, Opis 35, a.e. 3182; translated by Julia Cherneva, edited by Jordan Baev. Obtained by the Bulgarian Cold War Research Group. https://digitalarchive.wilsoncenter.org/document/116453. 
announcement, Juan Jose complained about the state of monuments around the city and suggested that "maybe the new Poder Popular has the answer."233 Signing off “revolucionariamente," Juan's letter was part of a pattern, not only in format but also in its subtle critique of the inefficiencies of the state.

The first complaints published by the newspaper pointed to not only issues with the state of monuments and sidewalks, but also the lack of organization. Although the province organized construction brigades, the amount of work continued to mount. Brigades replied to the local Committee for the Defense of the Revolution (CDR) member's questions regarding the slowing or sudden stop of work in their sidewalks; they explained that a lack of equipment was a factor. However, Apartado 133 entries exposed that there was more to the issue than the lack of equipment. In an anonymous complaint, a member of CDR number two asked that the persons responsible for the abandoned equipment at the Camilo Cienfuegos suburb. Workers were told to speed up their work because the scaffold was needed for another project. The cederista confirmed that the machine was not picked up, and it was beginning to rust. With an incredulous tone, the author asked if anyone had noticed the missing equipment and adopted the rhetoric of the revolutionary government to demand action:

"These are irresponsibilities that must be rigorously punished by law since it is our working people who create with the fruit of their labor all the material wealth

233 “Apartado 133,” Girón (December 26, 1974). 
of this country. We demand an answer, not a justification, and, if appropriate, a sanction from our courts." 234

The rusting scaffold became the subject of additional complaints, but this was not the only forgotten equipment. In a January 1975 complaint a resident described the abandoned machine:“An important equipment ... It is a compressor of Czechoslovak origin, apparently in good condition." The letter goes on to explain that it is not clear which organ it belongs to; it was abandoned in an old factory yard with low tires. Not only was the equipment "very useful and beneficial," the letter emphasized it was necessary at that moment because of the "grand plan" to restore the streets. However, despite emphasizing how these abandoned tools could help in the plans to restore public spaces (a plan under the supervision of the OPP), abandoned equipment continued to pop up in different areas of the city. No one claimed ownership; sometimes, the equipment was abandoned for so long no one remembered why it was left behind in the first place.

Complaints about the mishandling of equipment were only a small portion of the topics covered in the section. Consumer experiences, from rationing to customer service and cleanliness, appeared at least once in the daily issues. An anonymous complaint bemoaned the troubles of making a line at Coppelia, the national brand of ice cream stores across the country:

"The queue does not advance, the reason for this is that more than half of the people (especially schoolchildren at certain hours) arrive, walk to the service window, and ask the person next in line to buy their ice cream. I think this should

234 “Apartado 133,” Girón, December 29, 1974. 
not be allowed anymore, and the girls who dispatch should be guided not to serve anyone unless there is an organized queue."

The reader went further and included that a sign should be placed where everyone could read, "to discipline and educate people ... so that school children know how to have order and discipline." ${ }^{235}$ The issue of long, disorganized lines at stores was not new, but Girón allowed its readers to offer a suggestion. Readers were aware of the public forum, and the fact that the Apartado welcomed proposals implied that administrative organs were paying attention.

People wrapped their dissatisfaction in the rhetoric of the revolutionary government. While in the equipment complaint the plans of the OPP were used as a reason for action, in the second it evoked the revolutionary government's emphasis on the education of the masses. These did not receive a reply, but others caught the attention of administrative organs. Jesús made sure that his demand would catch someone's attention. He began his letter by stating his "rights as a citizen of this province, want an explanation for a situation presented by us, the users, about the bad treatment of the general public... at the same time [I] propose that the guidelines established by the central organizations and, especially the interprovincial [bus] terminal of Matanzas." Jesús's wrote to the newspaper after he was denied a seat on a 4 AM bus and told to board the next bus. Not only did Jesus sign off "revolutionarily," he included the Revolution's slogan (Patria o

235 “Apartado 133,” Girón (January 7, 1975). 
Muerte, venceremos) and that of the OPP: "the power of the people, that is real power." 236

Although Jesús received a reply, the "Apartado" also became a space for the administration to fire back at its critics. In the opening sentence of Edilio's response, the administrator at the terminal corrected Jesús's recollection by saying that he listed the wrong number. Edilio identified the bus route and the bus driver that denied Jesús a seat as "Juan Sardiñas, currently a fellow in active service in the revolutionary armed forces and who is on a commission of service in our terminal." The administrator not only painted Jesús's memory as unreliable, but he also listed the service of the driver, Juan, to convey him as an honorable man. But highlighting the error in Jesus's account was not enough, and Juan, the military man fulfilling his service for the nation, placed Jesís' character into question by saying that Jesus's "attitude was not the most correct because he did not express himself properly."${ }^{237}$ With those words, Edilio signed off "revolutionarily" and repeated the Revolution's slogan but not the OPPs. In another instance, the administrator questioned the identity of individuals submitting complaints to the newspaper. Because of the nature of the section, he believed that people were not using their real names; thus, these complaints were likely made up or instigated to make the organ look bad.

Despite the comments regarding the identities behind the complaints, the newspaper continued to publish these for years. The complaints gathered within the first

\footnotetext{
236 “Apartado 133,” Girón (February 6, 1975).

237 “Apartado 133,” Girón (February 11, 1975).
} 
six months of "Apartado 133" showed how the frustrations tied to Cubans consumer experiences were becoming routine and placing into question messages of progress central to the Revolution's emotive regime. These complaints did not fit into the early gendered image of consumption from the sixties. Matanzas's women, men, and youth actively contributed to the section. However, each consumer group had specific interests. While Cuban youths often wrote to the editors to ask about entertainment, including movies, musical performances, as well as the lack of spaces for recreation, adults were concerned about public services and consumer goods. While male consumer complaints centered around public services and gastronomy, women's complaints illustrated the continuities of rationing issues.

\section{PLEASURE: THINKING BEYOND SATISFACTION}

In his central report to the First Congress of the Cuban Communist Party (PCC), Fidel Castro defined a goal:

"In the formation of our communist conscience, the elevation of the level of material life is and must be a noble and just objective of our people to reach their dedicated work in the natural environment where we live. But at the same time, we must be aware that this medium is limited, that every gram of wealth must be taken from nature based on effort, that material goods are created to meet real and reasonable needs of the human being; that the superfluous must be discarded and that our society cannot be guided by the concepts, habits and absurd deviations 
with which the decaying system of capitalist production has infected the world." 238

The influence of Marx and Engels in the rhetoric surrounding material culture and consumption were symbolic of Cuba's march toward a planned economy and institutionalization. Not only would Cuba become a member of COMECON and enter new trade deals with the Eastern bloc, in 1974, but the Organs of Peoples Power (OPP) also marked the institutionalization of Cuba's administrative bodies. The figures of Lenin, Marx, and Engels presided over the first meeting of the experimental Organs of Peoples Power in Matanzas. The three figures did not look out at the audience; instead, their gaze was focused on Che Guevara, who looked up to the Soviet icons. ${ }^{239}$ But before their images appeared in the OPP ceremonies, their words inspired the work of ICIODI. While scholars debated the extent of Cuba's Sovietization in the seventies, the photos from Matanzas and the work of ICIODI illustrate how the Soviet presence went beyond the political and defined the contours of rational consumption for Cubans.

\footnotetext{
238 “Informe central al Primer Congreso de PCC," Bohemia (December 1975).

239 This image is ironic as it implies that Che Guevara looked up to the Soviet ideologues. During a conversation with Héctor Rodríguez Llompart, he expressed to me that Guevara appreciated the Soviet Union but did not trust or like them. Guevara did not want Soviet intervention in Cuban affairs, especially its economy.
} 


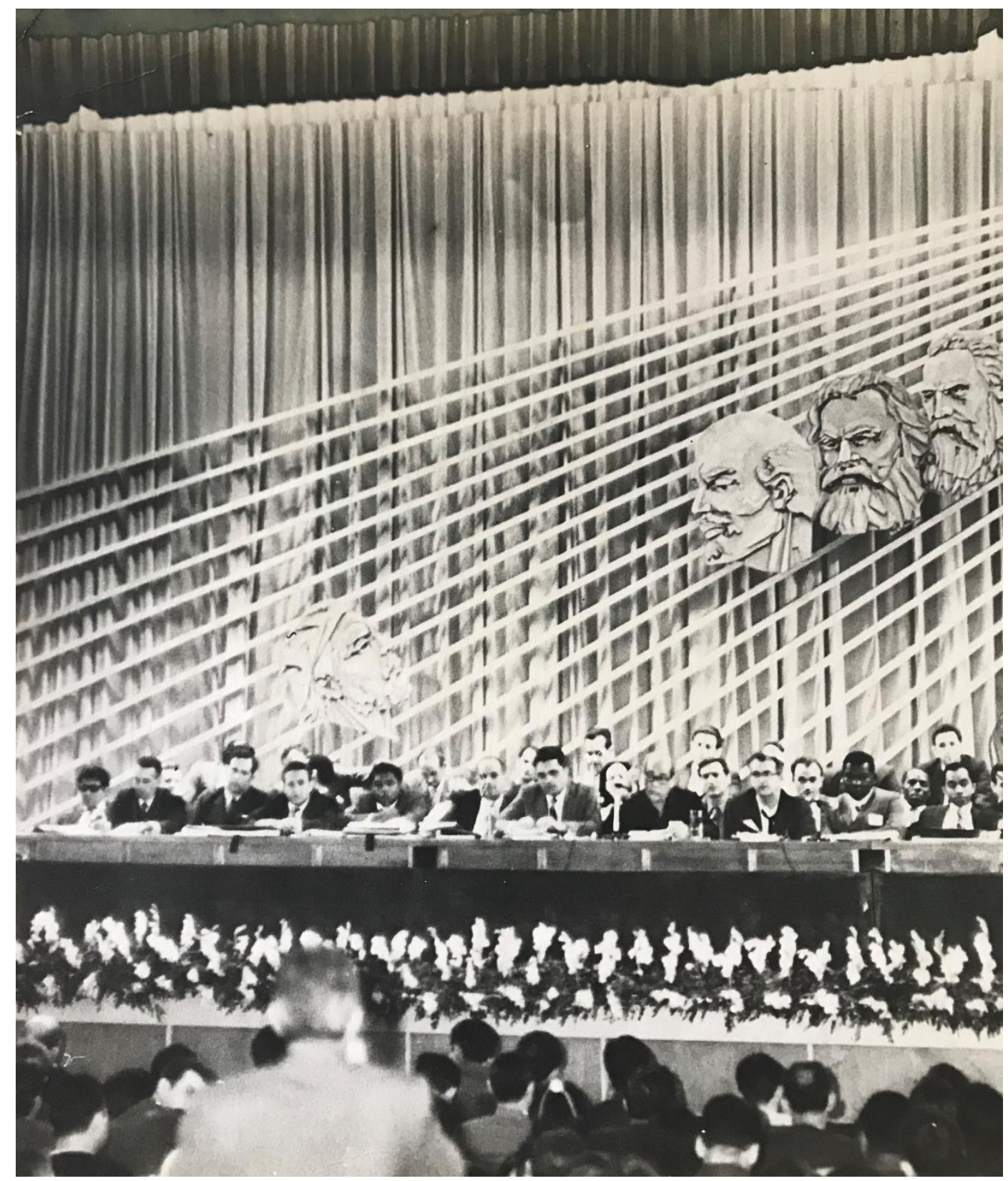

Figure 4.1. 1974: Inaugural meeting of the first Organs of Peoples Power, Matanzas, Cuba. Location: Teatro Sauto, Matanzas.

Notwithstanding the influence of Marx and Engels, ICIODI could not control the consumer experiences that troubled Cubans. Although by the late sixties participants in the Lewis study expressed their frustrations with the consumer culture of rationing, they thanked the Revolution for improving their living conditions. The failure of the 1970 
harvest marked a shift, and although carnival and festival culture fulfilled the promise of celebrations, its effects were temporary, and Cubans had expected a change in 1970. The data collection efforts for the 1970 census reveals that the revolutionary government was struggling to rally the masses. The inclusion of material culture in the census and the founding of ICIODI were part of the official reaction to the weakening of the Revolution's emotive regime. Despite official management of Cuban affects, including celebrations and the scientific approach to manufacturing satisfaction, the emotive regime could not control how emotive communities, such as consumers, would react. Not only did people lose the feeling of euphoria that marked the early sixties, they now experienced a daily reminder of the Revolution's fault when they went to the market, theater, restaurant, or looked outside their windows at the abandoned equipment. Creating a sense of satisfaction solidified into an emotional challenge for the revolutionary government that seeped into public spaces, including local newspapers.

Still, it is important to highlight how some experienced pleasure and indulged in consumer goods and leisure activities, such as wine and hotel vacations, even as scarcity and infrastructure issues marked Cubans' daily lives during the second decade. In the seventies, an emerging group of Cuban technical experts benefitted from the return of material incentives in workplaces that included electronic home appliances, reservations at restaurants, and vacations at Cuban hotels. Studies about time and leisure by the ICIODI coincided with a rise in travel and leisure activities in the seventies as well. ${ }^{240}$

\footnotetext{
${ }^{240}$ JUCEPLAN figures and reports indicate a growth in the spaces for leisure toward the end of the seventies.
} 
One Cuban blogger, Carlos Rodríguez Búa, recalled his vacation with his wife in 1974: "Finita and I went on vacation and we were surprised, we were practically alone in the hotel ... we ate, we drank industrial quantities of Chilean wine, abundant in Cuba then, and we ate a lot of fish, seafood, and especially Caguama (sea turtle) that we had not tried and that looked more like beef." ${ }^{241}$ His memories of food, drink, and travel contrasts the everyday emotions that surface in this study (disillusionment and dissatisfaction) as a challenge to the Revolution's emotive regime. They show that there were spaces for joy and satisfaction outside of the carnival scene. However, his memory of an empty hotel indicates that these spaces were not accessible to all Cubans.

A discussion of satisfaction and pleasure must include a description of the realm of illicit consumption and the extra-official exchanges that often destabilized the emotive regime. Opportunities for illicit pleasures expanded as the emotive regime adopted more restrictive measures of control in all spaces of Cuban life. For example, listening to the Beatles was a moment of illicit pleasure at times that official managers (for example, Jorge Serguera) deemed their music subversive to the Revolution's emotive regime. Consumption practices also expanded to the realm of illicit pleasures; throughout the seventies, an undeterred black market included everything, from cigarettes to meat and refrigerators.

${ }^{241}$ Carlos Rodríguez Búa, "La playa," Memorias de un cubano (blog), April 3, 2014, https://memoriascubano.blogspot.com/2014/04/una-playita-cualquiera-en-cuba.html. 


\section{CONCLUSION}

This chapter detailed the work of officials, who worked to create a sense of widespread satisfaction among Cuban consumers as a way to oversee and manipulate the feelings and reactions of the community. These attempts, of course, coexisted with the reactions of consumers themselves. While ICIODI became an established institute to identify tactics to manage the regime, consumers also found ways to voice their frustrations. Officials could not anticipate that consumers would frame their feelings using the emotional registers of the regime. Despite the frustration, officials continued to support the work of ICIODI and invested in studies of time and leisure. These studies continued into the third decade of the Revolution. The growth of the institute during the second decade indicates that creating and maintaining satisfaction transformed into an important aspect for the successful management of the Revolution' emotive regime.

Future studies of consumption in Cuba must take into account that identifying sources of pleasure can also help us understand the trends of memory and nostalgia amongst generations of Cubans inside and outside of the island. Soviet scholars note that it is possible to locate places, objects, and moments of pleasure in the everyday. Studies about everyday pleasures in the Eastern bloc question to what extent officials defined legitimate forms of pleasure and the agency of groups and individuals in producing pleasure. ${ }^{242}$ Throughout the seventies, the Soviet presence was felt beyond the political and administrative trajectory, and the influx of Soviet material goods and visual culture made the second decade stand out from the first ten years of the Revolution. In the early

\footnotetext{
${ }^{242}$ See Susan E. Reid and David Crowley, eds., Pleasures in Socialism (Chicago: Northwestern University Press, 2012).
} 
2000s, signs of nostalgia for Soviet culture that permeated everyday life materialized in the work of literary scholars and the consumer goods sold in Cuban streets and Miami stores. ${ }^{243}$ In an edited volume, editors Jacqueline Loss and José Prieto gathered scholars to reflect on the impact of los Soviets in modern-day cultural and artistic interpretations. More importantly, they identified one group bound by their consumer experiences and nostalgia for Eastern bloc cartoons: the muñequitos rusos generation. ${ }^{244}$ The children that grew up watching Soviet cartoons on national television during the seventies and eighties created virtual spaces, like blogs and social media groups, to reminisce. But the nostalgia went beyond the virtual spaces, shirts with the faces of the cartoon characters were also sold in Cuba, and in 2013 a restaurant, Nazdarovie, welcomed visitors to step into a Soviet time capsule with a view of el Malecón. ${ }^{245}$ While Cubans on the island sought to recreate aspects of their childhood memories, stores in Miami catering to Cuban palettes also made room on their shelves for the Russian canned meats and perfumes that became an integral part of Cuban consumer culture in the seventies. Rodríguez Búa's memories of leisure, the muñequitos Rusos generation, and the subculture of Cuban Soviet nostalgia suggests that the formal structures that defined everyday experiences also had the potential to provide pleasures.

\footnotetext{
${ }^{243}$ See Jacqueline Loss, "Vintage Soviets in post-Cold War Cuba," Mandorla: Nueva Escritura de las Américas 7 (2003): 79-84.

${ }^{244}$ Aurora Jácome, “The Muñequitos Rusos Generation” in Caviar with Rum, 27-30.

${ }^{245}$ On the commercialization of socialist nostalgia in Russia, see Serguei Alex Oushakine, "We're Nostalgic but We're Not Crazy”: Retrofitting the past in Russia," The Russian Review 66, no. 3 (2007): 451-82.
} 


\section{CONCLUSION}

My childhood memories of carnival are vague, but I can still recall the excitement in the air, and the families walking to the designated parade route. Carnival felt foreign compared to the monotony that permeated everyday life for a child growing up during Cuba's Special Period in the 1990s. During my teens, I returned to Cuba in the summers, and it is those carnival experiences that stand out. Summer became fun, loud, and, for once, grandparents overlooked curfew. When I returned to conduct research in Cuba in the summer of 2018, I did not experience carnival; instead, I searched for it in the archive and found it in everyday conversations. During the second leg of the trip, carnival became all I heard of. It was July, and I was back in Matanzas, reconnecting with family and friends in-between long, hot days in the archives. By week two, I could not believe what was happening: dengue began to spread. One after another, stories over cafecito reminded me that I packed everything but mosquito repellent. Yet, as I sat in living rooms, balconies, and porches, hearing about this neighbor or that good friend lying in a secluded wing of the hospital, people did not linger on the possibility that they might be the next to feel the fevers of the disease. Most barely questioned the delayed reaction from officials in raising the alarm of a possible epidemic, or that it took two full hospital wings to prompt daily, national television advisories about proper water storage and garbage disposal. The big question in everyone's mouth was "vamos a tener

carnaval/are we going to have carnival?" By the end of the month, I did not bat an eye at the mention of dengue; instead, I joined in asking and wondering what would happen to carnival that summer. The clash between the initial shock of dengue and my eventual assimilation into the mass obsession with carnival left me bewildered. 
Anthropologist Hannah Garth explains that the obsession with carnivals for Cubans is located at the intersection of traditions, time, and consumption. This dissertation coincides with Garth's conclusion that celebrations are temporal breaks from the routine that also have a revitalizing effect on individuals and groups. While Garth explains that carnival regained importance for Cubans in the nineties, "a period of scarcity, constant change, and uncertainty," I find that these inferences could describe any period of the Cuban Revolution. ${ }^{246}$ This is the case of chapter one, when carnival returned at a time of state-imposed rationing, economic failure, and the waning enthusiasm for mass participation. The promise of carnival during the Revolution's second decade established the cycles of celebrations that continue to give Cubans something to look forward to every year. Carnival disappeared and re-appeared throughout the decades. Each time carnival made a grand return, it was in response to significant shifts in the emotive regime. In 2016, the anticipation for carnival not only coincided with a dengue outbreak, it was also the summer in which ratifications to the Cuban constitution were announced, but a law recognizing gay marriage scandalized portions of the population and rumors of a new currency spread.

As this study has shown, placing the Cuban Revolution within an emotive framework indicates that emotional management was vital to the endurance of the Revolution. The print culture represented the emotive repertoires of the regime; they were contradictory yet useful for officials. Mass organizations also bolstered surveillance of daily life through their magazines. Their publications framed everyday tasks, from a

\footnotetext{
${ }^{246}$ Hannah Garth, "Consumption, Temporality, and Celebration in Contemporary Santiago de Cuba," American Anthropologist 121, no. 4 (2019): 801-14.
} 
woman's cytological evaluation to painting a fence, as political participation, and support for the Revolution. Officials and organizations charged with improving Cuban society continually adopted and adapted strategies to manage the emotive shifts. While officials collected population data and transitioned into a period of institutionalization in the seventies, the information they gathered was more than the number of families per home. The state also employed resources to study what Cubans wanted and needed. Despite these efforts, the rational Cuban consumer remained an elusive ideal due to everyday experiences such as scarcity and a deficient infrastructure.

Locating the sources of discontent and pleasure will enable us to capture the histories of the Revolution from within. A study of emotions also creates a space for interdisciplinary approaches, conversations amongst Cuban scholars, and contributes to studies of gender, identity, and culture. As this dissertation has shown, a history of emotions is essential to expanding our understanding of the Cuban Revolution's second decade beyond the shade of gray often associated with the period. Studying the Revolution through its emotive shifts and legacies exposes a kaleidoscope of feelings and possibilities for writing about the Cuban Revolution. I conclude by proposing an exploration of emotions as starting point for histories of the Cuban Revolution from within.

\section{EMOTIVE PERIODS}

Lastly, this dissertation offers a new periodization of the Cuban Revolution through a history of emotions. It shifts periods back from events to the swelling feelings that often precede or linger beyond events. While Cubans' sense of disappointment and dissatisfaction swirl together in our present-day characterizations of the Special Period, 
we can trace these to distinct emotive periods. As these feelings accumulated over the decades, they also became the sediment of current ways that Cubans emotionally engage the Revolution.

The September 1980 issue of the Cuban magazine Mujeres shared a letter through the "Conversation" section that the editors titled "Repudiation letter from a mother to her traitorous daughter, [traitorous] to her homeland." In the open letter to her daughter, Rufina Matos Barrios began by recognizing the "deep indignation" that moved her to write words "from the depths of the Heart of a Revolutionary Mother." Repeating the terms used by Fidel Castro in speeches, Matos Barrios branded her daughter a worm, trash, and a social scourge for choosing to leave the country during the Mariel exodus. ${ }^{247}$ The events that unfolded on April 1, 1980, preceded the exodus of over 125,000 Cubans through the port of Mariel. ${ }^{248}$ That day, five Cubans crashed a bus into the Peruvian embassy in Havana and asked for asylum. Thousands flooded the embassy within days seeking diplomatic protection. Fidel Castro declared that the port of Mariel would be the gateway for a mass exodus of Cuba's 'escoria/ social scourge'. In the days leading up to the opening of the port, Castro called upon mass organizations and the armed forces to organize a grand march supporting the Revolution. Castro identified two types of wars, conventional and popular, and declared that Cuba was ready. The mass gathering planned

247 “Conversemos,” Mujeres (September 1980): 9.

${ }^{248}$ For more about the Mariel exodus see Victor Andres Triay, The Mariel Boatlift: A Cuban-American Journey (Gainesville: University Press of Florida, 2019); Kathleen Dupes Hawk, Ron Villella, Adolfo Leyva de Varona, and Kristen Cifers, Florida and the Mariel Boatlift of 1980: The First Twenty Days (Tuscaloosa: The University of Alabama Press, 2014). 
for May 17, 1980, would be a show of forces, and it would demonstrate that in the battlefield of popular opinion, the Cuban Revolution continued to be a "popular revolution."

Matos Barrios' letter echoed the tensions that threatened to destabilize the Revolutionary government's control; it also exemplified the state's emotive management, specifically through anger. Participation in acts of repudiation required coworkers, neighbors, and classmates to shame individuals and families leaving the country publicly. Neighborhood Committees in Defense of the Revolution helped organize groups in front of the homes of people identified as deserters; the crowds included children and adults who chanted and threw rocks and eggs. Acts of repudiation dated back to the early years of the Revolution, but it was in the early eighties that they became a primary vehicle for the Revolution's message of popular support. Not only were these acts performances of power, but they also signaled a shift in how officials managed the Revolution's emotive regime in the previous decade. When Cubans living in exile trickled into the island at the end of the seventies, the influx of material goods from relatives residing in capitalist nations underlined what Cubans on the island so desperately lacked; it also strengthened a sense of dissatisfaction with the Revolution's consumer options. The accumulation of these emotions prompted thousands of Cubans to crash into the Peruvian embassy and ask for refuge. Love, enthusiasm, joy, disillusionment, and frustration preceded the anger characteristic of acts of repudiation during the beginning of the Revolution's third decade (1978-1988). 


\section{BIBLIOGRAPHY}

\section{ARCHIVES AND ARCHIVAL SOURCES}

Cuban Heritage Collection, University of Miami Libraries

Cuban Ministry of Culture Archive

Latin American and Caribbean Collection, University of Florida Libraries

Oficina Nacional de Estadística e Información Archive, Matanzas

Oscar and Ruth Lewis Papers (1944-76), University of Illinois Archives

Periodicals and Magazines

Bohemia

Coctel

Con la Guardia en Alto

Girón

Granma

Mujeres

Fidel Castro Speeches

"Discurso en la inauguración de un pueblo de 120 casas, parte de un plan de más de 600 casas, construidas en 1967, en el Cordón de La Habana, autopista del mediodía, el 6 de enero de 1968."

"Discurso pronunciado al conmemorarse el IX Aniversario del Triunfo de la Revolución, en la Plaza de la Revolución, el 2 de enero de 1968."

"Discurso pronunciado en el acto conmemorativo del XI Aniversario de la Acción del 13 de marzo de 1957, efectuado en la escalinata de la Universidad de La Habana, el 13 de marzo de 1968."

"Discurso pronunciado en el acto para dar inicio a la etapa masiva de la zafra de los 10 Millones de Toneladas, efectuado en el Teatro "Chaplin", La Habana, el 27 de octubre de 1969." 
"Discurso pronunciado por el Comandante en Jefe Fidel Castro Ruz en la clausura de la plenaria nacional de la industria básica, efectuado en el teatro de la CTC, el 7 de diciembre de 1970."

"Discurso pronunciado en la clausura del Primer Congreso Nacional de Educación y Cultura, efectuado en el Teatro de la CTC, el 30 de abril de 1971,"

$\mathrm{B} \log s$

Asociación Pro Libertad de Prensa

Rodríguez Búa, Carlos. Memorias de un cubano

El hombre de Cuba nuestra

Memorias de Cuba

Pedraza Ginori. El Blog de Pedraza Ginori

Publications

ICIODI. Investigaciones científicas de la demanda en Cuba. Havana: Editorial Ciencias Sociales, 1979.

Junta Central de Planificación. Censo de Población y Viviendas, 1970. Havana: Obre, 1975.

Las Estadisticas Demograficas Cubanas. Havana: Editorial de Ciencias Sociales, 1975.

First Congress of the Communist Party of Cuba. Central Report. Havana: Department of Revolutionary Orientation of the Central Committee of the Communist Party of Cuba, 1975.

OTHER

FACULTY SENATE OF FLORIDA INTERN. UNIV. v. ROBERTS. Case No. 0621513-CIV.

News from the Center 7. Washington, D.C.: Library of Congress, 1970.

“Report on Fidel Castro's Visit to Bulgaria and Bulgarian-Cuban relations," May, 1972, History and Public Policy Program Digital Archive, Central State Archive of Bulgaria (TsDA), Sofia, Fond 1-B, Opis 35, a.e. 3182 


\section{SECONDARY}

Abel, Christopher. "Reviewed Work: Cuba: Between Reform and Revolution by Louis A. Pérez Jr.” Bulletin of Latin American Research 9 no. 1 (1990): 143-4.

Anderson, Thomas F. Carnival and National Identity in the Poetry of Afrocubanismo. Gainesville: University Press of Florida, 2011.

Arús, María A. Cabrera. "The Material Promise of Socialist Modernity: Fashion and Domestic Space in the 1970s." In The Revolution from Within Cuba 1959-1980, edited by Michael Bustamante and Jennifer Lambe.189-217.Durham: Duke University Press, 2019.

Báez, Luis. Cartas sobre la mesa. Mexico City: Siglo Veintiuno Editores, 1984.

Banner, Lois W. "Review of An Emotional History of the United States." Journal of Interdisciplinary History 30, no. 3 (1999): 546-547.

Bell Lara, José, Tania Caram León, and Delia Luisa López. Documentos de La Revolución Cubana, 1960. Havana: Editorial De Ciencias Sociales, 2008.

Blum, Denise F. Cuban Youth and Revolutionary Values. Austin: University of Texas Press, 2011.

Brandenberger, David. Propaganda State in Crisis: Soviet Ideology, Indoctrination, and Terror under Stalin, 1927-1941. New Haven: Yale University Press, 2014.

Brenner, Philip, et al., eds. A Contemporary Cuba Reader: Reinventing the Revolution. Lanham, MD: Rowman and Littlefield, 2008.

Bustamante, Michael. "Historiar la Revolución desde los Estados Unidos.” Temas (2017): 4-5.

Bustamante, Michael, and Jennifer Lambe, eds. The Revolution from Within: Cuba, 1959-1980. Durham: Duke University Press, 2019.

Bustamante, Michael. “Anniversary Overload? Memory Fatigue at Cuba's Socialist Apex" In The Revolution from Within, 1959-1980 edited by Michael Bustamante, and Jennifer Lambe. 218-243.Durham: Duke University Press, 2019.

Canfux, Jaime, and John A. Mateja. "A Brief Description of the 'Battle for the Sixth Grade." Journal of Reading 25, no. 3 (1981).

Cannabrava Cilho, Paulo. En el ojo de la tormenta. Madrid:Plaza y Valdés, 2000. 
Casavantes Bradford, Anita. The Revolution Is for the Children: The Politics of Childhood in Havana and Miami, 1959-1962. Chapel Hill: University of North Carolina Press, 2014.

Castellanos, Ernesto Juan. John Lennon en La Habana: With a Little Help from My

Friends.Havana: Ediciones Unión, 2005.

Chancy, Myriam J.A. From Sugar to Revolution: Women's Visions of Haiti, Cuba, and the Dominican Republic. Ontario: Wilfrid Laurier University Press, 2012.

Chase, Michelle. Revolution Within the Revolution: Women and Gender Politics in Cuba, 195-1962. Durham: Duke University Press, 2015.

Chatterjee, Choi, David L. Ransel, and Mary Cavender, eds. Everyday Life in Russia Past and Present. Bloomington: University of Indiana Press, 2015.

Cheng, Yinghong. Creating the 'New Man: From Enlightenment Ideals to Socialist Realities. Honolulu: University of Hawai'i Press, 2009.

Chernyshova, Natalya. Soviet Consumer Culture in the Brezhnev Era. New York: Routledge, 2013.

Corral, Oscar, and Noah Bierman. "Schools Face Ban on Trips to Cuba." Miami Herald (February 28, 2006): B1.

Corral, Oscar. "Lawmakers Put Focus on Castro.” Miami Herald (February 23, 2004): B1.

Cuadra, Manuel. Aspiraciones y espacios de una Revolución: Arquitectura y urbanismo en Cuba 1959-2018. Germany: Kassel University Press, 2019.

Derrida, Jacques. Archive Fever: A Freudian Impression. Chicago: University of Chicago Press, 1998.

Domínguez, Jorge I. “Twenty-Five Years of Cuban Studies.” Cuban Studies 25 (1995): 3-26.

Erisman, H. Michael, and John M. Kirk. Cuban Foreign Policy Confronts a New International Order. Boulder, CO: Lynne Rienner Publishers, 1991.

Farber, Samuel. "Reviewed Work: The Cuban Revolution into the 1990s. Cuban Perspectives by Centro de Estudios sobre América." Cuban Studies 25 (1995): 264-66. 
Fernández, Damián J. Cuba and the Politics of Passion. Austin: University of Texas Press, 2000.

Fernández, Damián J., ed. Cuban Studies since the Revolution. Gainesville: University Press of Florida, 1992.

Díaz-Briquets, Sergio, and Jorge F. Pérez-López. Conquering Nature: The Environmental Legacy of Socialism in Cuba. Pittsburgh: University of Pittsburgh Press, 2000.

Dominguez, Jorge. Cuba: Order and Revolution. Cambridge: Harvard University Press, 1978.

Dupes Hawk, Kathleen, Ron Villella, Adolfo Leyva de Varona, and Kristen Cifers. Florida and the Mariel Boatlift of 1980: The First Twenty Days. Tuscaloosa: The University of Alabama Press, 2014.

Farley, Jan. Living Politics, Making Music: The Writings of Jan Fairley. New York: Routledge, 2016.

Fitzpatrick, Sheila. "Revisionism in Retrospect: A Personal View." Slavic Review 67, no. 3 (2008): 691.

Fitzpatrick, Sheila. "Revisionism in Soviet History." History and Theory 46, no. 4 (2007): 77-91.

Fitzpatrick, Sheila. A Spy in the Archives. New York: Palgrave Macmillan, 2013.

Fornet, Jorge. El 71: Anatomía de una crisis. Havana: Letras Cubanas, 2013.

Garth, Hanna. "Consumption, Temporality, and Celebration in Contemporary Santiago de Cuba.” American Anthropologist 121, no. 4 (2019): 801-14.

Garth, Hanna. Food in Cuba: The Pursuit of a Decent Meal. Redwood City: Stanford University Press, 2020.

Gordon-Nesbitt, Rebecca. To Defend the Revolution Is to Defend Culture. Oakland: PM Press, 2015.

Goprsuch, Anne E. “'Cuba, My Love': The Romance of Revolutionary Cuba in the Soviet Sixties." The American Historical Review 120, no. 2 (2015): 497-526. 
Green, James. "Interview of Margaret Crahan: "We Cannot Remain Silent." We Cannot Remain Silent, Brown University Library, accessed October 12, 2019, https://library.brown.edu/wecannotremainsilent/megan-crahan/.

Grenier, Guillermo, and Alex Stepick, eds. Miami Now! Immigration, Ethnicity, and Social Change. Gainesville: University Press of Florida, 1992.

Grenier, Guillermo. "The 1991 FIU Cuba Poll: Views on Policy Options toward Cuba Held by Cuban-American Residents of Dade County, Florida.” FIU Digital Commons (Florida International University)

https://digitalcommons.fiu.edu/cgi/viewcontent.cgi?article=1005\&context=cuba_poll. Accessed October 13, 2019.

Guerra, Lillian. Visions of Power in Cuba Revolution, Redemption, and Resistance, 1959-1971. Chapel Hill: University of North Carolina Press 2012.

Guerra, Lillian. "The Reel, Real, and Hyper-Real Revolution.” In Scripting Revolution: A Historical Approach to the Comparative Study of Revolutions, edited by Dan Edelstein and Keith Michael Baker. 267-286.Stanford: Stanford University Press, 2015.

Helbsky, Sandor, and John M. Kirk, eds. Cuba in Transition: Crisis and Transformation. Boulder: Westview Press, 1992.

Hoffmann, David L. Stalinist Values: The Cultural Norms of Soviet Modernity, 19171941. Ithaca: Cornell University Press, 2003.

Igmen, Ali. Speaking Soviet with an Accent: Culture and Power in Kyrgyzstan. Pittsburgh: University of Pittsburgh Press, 2012.

Jácome, Aurora. “The Muñequitos Rusos Generation.” In Caviar with Rum: Cuba-URSS and the Post-Soviet Experience, edited by Jacqueline Loss and José Prieto. 27-35. New York: Palgrave Macmillan, 2012.

Johnson, Peter. "Toward the Rectification of Shortfalls and Production Constraints Affecting Cuban Research: Bibliography for the Year 2000." In Cuban Studies Since the Revolution, edited by Damián J. Fernández. 284-290. Gainesville: University Press of Florida, 1992.

Kirk, Emily J. "Cuba's National Sexual Education Program: Origins and Evolution." Cuban Studies 49 (2020): 289-309.

Kumaraswami, Par. "Cultural Policy and Cultural Politics in Revolutionary Cuba: ReReading the Palabras a Los Intelectuales (Words to the Intellectuals)." Bulletin of Latin American Research 28, no. 4 (2009): 527-41. 
LeoGrande, William M., and Peter Kornbluh. Back Channel to Cuba Cuba: The Hidden History of Negotiations Between Washington and Havana. Durham: Duke University Press, 2015.

Lewis, Oscar M., Ruth M. Lewis, and Susan M. Rigdon. Four Men: Living the Revolution, An Oral History of Contemporary Cuba. Urbana: University of Illinois Press, 1977.

Lewis, Oscar M., Ruth M. Lewis, and Susan M. Rigdon. Four Women: Living the Revolution, An Oral History of Contemporary Cuba. Urbana: University of Illinois Press, 1977.

Linger, Eloise. "Reviewed Work: Historia de la Revolución Cubana by Nicolás Garófalo Fernández." Cuban Studies 27 (1998): 300-2.

Lipman, Jana. Guantanamo: A Working-Class History between Empire and Revolution. Los Angeles: University of California Press, 2008.

Loss, Jacqueline. Dreaming in Russian: The Cuban Soviet Imaginary. Austin: University of Texas Press, 2015.

Loss, Jacqueline."Vintage Soviets in Post-Cold War Cuba." Mandorla: Nueva Escritura de las Américas 7 (2003): 79-84.

Loss, Jacqueline, and José Manuel Prieto. Caviar with Rum: Cuba-USSR and the PostSoviet Experience. New York: Palgrave Macmillan, 2012.

Luke, Anne. "Listening to los Beatles: Being Young in 1960s Cuba." In The Socialist Sixties, edited by Anne E. Gorsuch and Diane P. Koenker. 287-303 Bloomington: Indiana University Press, 2013.

Martínez, María Elena. "Archives, Bodies, and Imagination: The Case of Juana Aguilar and Queer Approaches to History, Sexuality, and Politics." Radical History Review 1 (October 2014): 159-182.

McDowell, Edwin. "Did Castro Double-Cross Oscar Lewis?" New York Times (October 26, 1981). https://www.nytimes.com/1981/10/26/books/did-castro-double-crossoscarlewis.html. Accessed September 1, 2019.

Meireles, Waldo Acebo. "Las escuelas en el campo: una continuación." Cubaencuentro (July 22, 2017), https://www.cubaencuentro.com/cuba/articulos/las-escuelas-enelcampo-una-continuacion-330090. Accessed May 2, 2020. 
Mesa-Lago, Carmelo. "Availability and Reliability of Statistics in Socialist Cuba (Part One)." Latin American Research Review 4, no. 1 (1969): 53-91.

Mesa-Lago, Carmelo. Market, Socialist, and Mixed Economies: Comparative Policy and Performance: Chile, Cuba, and Costa Rica. Baltimore: The Johns Hopkins University Press, 2000.

Mesa-Lago, Carmelo. The Economy of Socialist Cuba. Albuquerque: University of New Mexico Press, 1981.

Mestas, María del Carmen, Gladys Eques, and Mercedes Verdeses. "Cubanas en Revolución." Mujeres (November 16, 2001).

Milanés, Pablo. Con luz propia. Navarra: Rave, 1994.

Moore, Robin. “¿Revolución con Pachanga? Dance Music in Socialist Cuba.” Canadian Journal of Latin American and Caribbean Studies / Revue Canadienne Des Études Latino-américaines Et Caraïbes 26, no. 52 (2001): 151-77.

Moore, Robin. "Transformations in Cuban Nueva Trova, 1965-95." Ethnomusicology 47, no. 1 (2003): 1-41.

Oushakine, Serguei Alex. "We're Nostalgic but We're Not Crazy": Retrofitting the Past in Russia." The Russian Review 66, no. 3 (2007): 451-82.

Pariseau, Earl, ed. Cuban Acquisitions and Bibliography. Washington, D.C.: Library of Congress, 1970.

Pérz, Eudelio. Cuba, ayer y hoy. California: International Windmills Edition, 2011.

Pérez, Louis. "Toward a New Future, From a New Past: The Enterprise of History in Socialist Cuba." Cuban Studies 15, no. 1 (1985), 1-15.

Pérez, Louis A. Cuba: Between Reform and Revolution. Fifth ed. New York: Oxford University Press, 2015.

Pérez, Louis A. The Structure of Cuban History. Chapel Hill: University of North Carolina Press, 2013.

Petrone, Karen. Life Has Become More Joyous, Comrades. Bloomington: Indiana University Press, 2000.

Plamper, Jan, William Reddy, Barbara Rosenwein, and Peter Stearns. "The History of Emotions: An Interview with William Reddy, Barbara Rosenwein, and Peter Stearns." History and Theory 49, no. 2 (2010): 237-65. 
Portes, Alejandro, and Alex Stepick. City on the Edge: The Transformation of Miami. Berkeley and Los Angeles: University of California Press, 1993.

Reddy, William. The Navigation of Feeling. New York: Cambridge University Press, 2001.

Reddy, William. The Making of Romantic Love: Longing and Sexuality in Europe, South Asia, and Japan. Chicago: University of Chicago Press, 2012.

Reid, Susan E., and David Crowley, ed. Pleasures in Socialism. Chicago: Northwestern University Press, 2012.

Roca, Sergio G. "State Enterprises in Cuba Under the New System of Planning and Management (SDPE)." Cuban Studies 16 (1986): 153-79.

Rojas, Rafael. "The New Text of the Revolution." In The Revolution from Within, 19591980, edited by Michael Bustamante and Jennifer Lambe, 33-46.Durham: Duke University Press, 2019.

Rolfe, Malte. Soviet Mass Festivals, 1917-1991. Pittsburgh: University of Pittsburgh Press, 2013.

Santí, Enrico Mario. “José Martí and the Cuban Revolution.” Cuban Studies 16 (1986): 139-150.

Santí, Enrico Mario. "Preface.” Cuban Studies 28 (1999): xi.

Scarpaci, Joseph L., Roberto Segre, and Mario Coyula. Havana: Two Faces of the Antillean Metropolis. Chapel Hill: University of North Carolina Press, 2002.

School of International and Public Affairs, Florida International University. Hemisphere: A Magazine of the Americas 27 (Winter 2018).

School of International and Public Affairs, Florida International University. 2018 FIU Cuba Poll. https://cri.fiu.edu/research/cuba-poll/2018-fiu-cuba-poll.pdf.

Schwartz, Rosalie. Pleasure Island: Tourism and Temptation in Cuba. Lincoln: University of Nebraska Press, 1999.

Serra, Ana. The "New Man" in Cuba: Culture and Identity in the Revolution. Gainesville: University Press of Florida, 2007.

Smith, Lois M., and Alfred Padula. Sex and Revolution: Women in Socialist Cuba. New York: Oxford University Press, 1996. 
Smith, Robert C. "The Hispanic Foundation in the Library of Congress." The Hispanic American Historical Review 19, no. 4 (1939): 564-71.

Stearns, Peter N. and Carol Z Stearns. "Emotionology: Clarifying the History of Emotions and Emotional Standards." The American Historical Review (1985): 813-36..

Steedman, Carolyn. Dust: The Archive and Cultural History. Manchester: Manchester University Press, 2001.

Steinberg, Mark, and Valeria Sobol. Interpreting Emotions in Russia and Eastern Europe. DeKalb: Northern Illinois University Press, 2011.

Thomas, David, Simon Fowler, and Valerie Johnson. The Silence of the Archive. Chicago: Neal-Schuman, 2017.

Tomoff, Kiril, Golfo Alexopoulos, and Julie Hessler, eds. Writing the Stalin Era: Sheila Fitzpatrick and Soviet Historiography. New York: Palgrave Macmillan, 2011.

Triay, Victor Andres. The Mariel Boatlift: A Cuban-American Journey. Gainesville: University Press of Florida, 2019.

Valdés, Nelson. "Cuban Political Culture: Between Betrayal and Death." In Cuba in Transition: Crisis and Transformation, edited by Sandy Halebsky and John M. Kirk. 207-228. Boulder, CO: Westview Press, 1992. 
VITA

\title{
MAITE MORALES
}

\author{
Born Matanzas, Cuba
}

2007-2011

B.A., English

Second Major: History

Florida International University

Miami, Florida

2011-2013

M.A., History

Florida International University

Miami, Florida

2014-2020

Doctoral Candidate

Florida International University

Miami, Florida

Senior Program Coordinator

CasaCuba at Florida International University

Miami, Florida

\section{PUBLICATIONS AND PRESENTATIONS}

Ruscitti Harshman, D., Friedman, R., The Soviet Home: Domestic Ideology and Practice (Under consideration with Bloomsbury) contributed to the edited volume: "Assembled with Soviet Parts: Housing and Socialism in Post-Revolutionary Cuba"

Morales, M., (February 2019). "Legislation, the Press, and Everyday Life in Cuba, 197079," Paper presented at the Cuban Research Institute Conference, Miami, Florida International University.

Morales, M., (November 2018) "Re-Imagining the Street: Popular Festivals in 1970s Cuba," Paper presented at the Cuban Studies Symposium, Harvard University, Boston, Massachusetts.

Morales, M., (November 2016) "Mi Hogar: Soviet Products, Cuban Women, and Revolutionary Homes, 1960-70," Paper presented at the Association for Slavic, East European, and Eurasian Studies Conference, Washington D.C.

Morales, M., (February 2015) "Felix B. Caignet: En Papel Mulato,” Cuban Research Institute, Florida International University, Miami, Florida. 